\title{
Historical Archaeology in Texas: A Bibliography
}

William Moore

Center for Archaeological Research

Roger Moore

Center for Archaeological Research

Follow this and additional works at: https://scholarworks.sfasu.edu/ita

Part of the American Material Culture Commons, Archaeological Anthropology Commons, Environmental Studies Commons, Other American Studies Commons, Other Arts and Humanities Commons, Other History of Art, Architecture, and Archaeology Commons, and the United States History Commons

Tell us how this article helped you.

This Article is brought to you for free and open access by the Center for Regional Heritage Research at SFA ScholarWorks. It has been accepted for inclusion in Index of Texas Archaeology: Open Access Gray Literature from the Lone Star State by an authorized editor of SFA ScholarWorks. For more information, please contact cdsscholarworks@sfasu.edu. 


\section{Historical Archaeology in Texas: A Bibliography}

Creative Commons License

(c) (i) (8)

This work is licensed under a Creative Commons Attribution-NonCommercial 4.0 International License 


\section{HISTORICAL ARCHAEOLOGY IN TEXAS:}

\section{A BIBLIOGRAPHY}

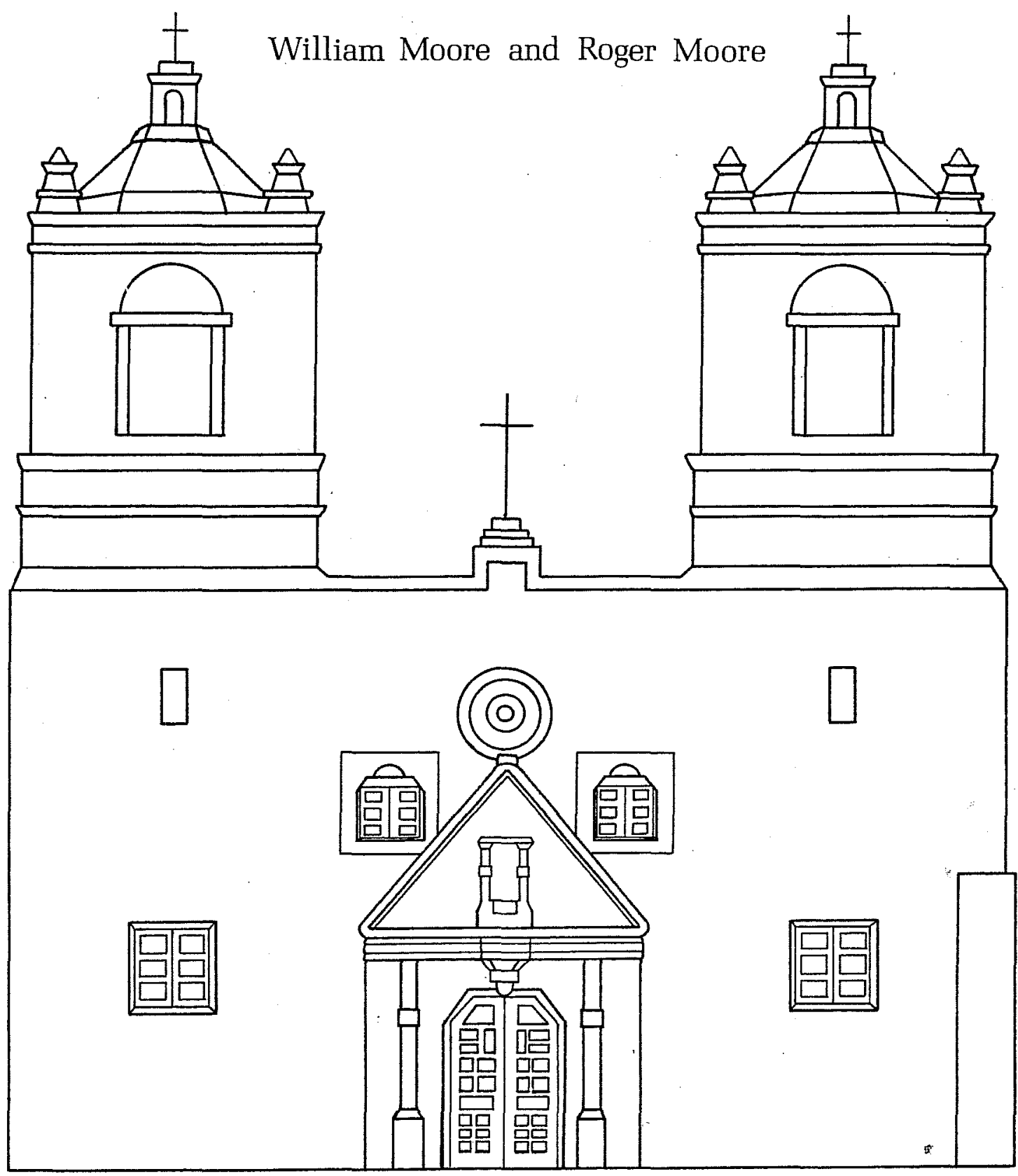

Center for Archaeological Research

The University of Texas at San Antonio

Guidebooks in Archaeology, No.2

1986 
HISTORICAL ARCHAEOLOGY IN TEXAS:

A BIBLIOGRAPHY

William Moore and Roger Moore

Center for Archaeological Research

The University of Texas at San Antonio ${ }^{8}$

Guidebooks in Archaeology, No. 2

1986 
Cover: Mission Concepción. San Antonio, Texas, drawn by Bruce E11 is, Center for Archaeological Research. The University of Texas at San Antonio. 
With the increased activity in Texas archaeology in recent years--by both professional and avocational archaeologists--there has been a tremendous growth in the literature for prehistoric and historic sites. It is hard for most of us to keep apace of all of these publications, and there is a great need for articles and books that synthesize these new data. There is also a demand for comprehensive bibliographies that enable us to track down references on a particular topic or involving a specific geographical area. On the academic side of archaeology, such bibliographies are of great value when students begin to hunt for references for semester projects. In contract archaeology, there is the need to have access to published reports when preparing site survey forms and reports on historic sites.

The publication in 1983 of Dan Fox's Traces of Texas History (Corona Press, San Antonio) provided the needed synthesis of historic archaeology in Texas. Now, through the work of William Moore and Roger Moore, the Center for Archaeological Research is pleased to publish this present bibliographic treatment of historic sites archaeology. It should be a useful adjunct to Fox's book, and we hope that it can be updated in the coming years in order to maintain its utility as a bibliographic tool. 


\begin{abstract}
Documented in this bibliography are the varied sources in which information concerning historical archaeology in Texas has appeared. In a11, 509 references are cross-referenced in this monograph with author, subject, and county. Much of the state is represented with subjects relating to 163 of the 254 Texas counties.
\end{abstract}


FOREWORD (Thomas R. Hester) . . . . . . . . . . . . . . . . . . i ABSTRACT . . . . . . . . . . . . . . . . . . . . . . . . . ii ACKNOWLEDGMENTS . . . . . . . . . . . . . . . . . . . . . . . . . viii INTRODUCTION . . . . . . . . . . . . . . . . . . . . . . . . 1 LIST OF ABBREVIATIONS . . . . . . . . . . . . . . . . . . . . . 2 AUTHOR . . . . . . . . . . . . . . . . . . . . . . . . 5 SUBJECT . . . . . . . . . . . . . . . . . . . . . . . 4 49

Architectural Styles . . . . . . . . . . . . . . . . 49 Boarding Houses... . . . . . . . . . . . . . . . . . . 49 Building Technology . . . . . . . . . . . . . . . . . . 49 Cabins . . . . . . . . . . . . . . . . . . . . . . 49 Camps............................. . . . . 50 Cathedrals ........................... 50 Cemeteries and Graves.. . . . . . . . . . . . . . . . . . . 50

Churches . . . . . . . . . . . . . . . . . . . . . 52

Commercial Sites . . . . . . . . . . . . . . . . . 52

Domestic Sites . . . . . . . . . . . . . . . . . . 52

Dugouts . . . . . . . . . . . . . . . . . . . . . 54

Ethnohistory . . . . . . . . . . . . . . . . . 55

Farmsteads . . . . . . . . . . . . . . . . . . 55

Features . . . . . . . . . . . . . . . . . . . . 56

Historic Indians . . . . . . . . . . . . . . . . . . 57

Industrial Sites ....................... 60

Inns/Stagecoach Stops .................... . . 64

Military Sites . . . . . . . . . . . . . . . . . . . 64

Miscellaneous Artifacts . . . . . . . . . . . . . . . . 69

Missions .. . . . . . . . . . . . . . . . . . . 70

Outbuildings . . . . . . . . . . . . . . . . . . . . . 72

Overviews and Syntheses... . . . . . . . . . . . . . . . . 73

Park Structures and Features . . . . . . . . . . . . . . . . . 74

Plantations........................... 74

Privies......................... . . 75

Public Buildings . . . . . . . . . . . . . . . . . . . 75

Ranches ........................... 75

Ranchos . . . . . . . . . . . . . . . . . . . . . . 76

Ranger Stations . . . . . . . . . . . . . . . . . . . . 77

Residences .. . . . . . . . . . . . . . . . . 77

Resorts . . . . . . . . . . . . . . . . . . . . . . 77

Schools and Academies . . . . . . . . . . . . . . . . . 77

Shipwrecks . . . . . . . . . . . . . . . . . . . . . . 78

Spanish Colonial Sites . . . . . . . . . . . . . . . . . . 79

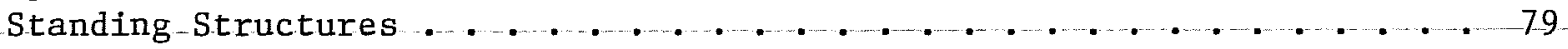

Surveys (Urban) . . . . . . . . . . . . . . . . . . 80 


\section{SUBJECT (continued)}

Towns and Communities . . . . . . . . . . . . . . . . . 80

Trading Posts... . . . . . . . . . . . . . . . . . . 83

Transportation Sites and Features... . . . . . . . . . . . 83

Trash Dumps and Scatters. . . . . . . . . . . . . . . . . 85

Water Sources and Control Structures . . . . . . . . . . . . 86

COUNTY . . . . . . . . . . . . . . . . . . . . . . 89

Anderson ............................... . . . . 89

Aransas . . . . . . . . . . . . . . . . . . . . . 89

Austin . . . . . . . . . . . . . . . . . . . . . . . 89

Bandera . . . . . . . . . . . . . . . . . . . . . . 89

Bastrop . . . . . . . . . . . . . . . . . . . . 89

Bee.... . . . . . . . . . . . . . . . . 89

Bell . . . . . . . . . . . . . . . . . . . . . 89

Bexar . . . . . . . . . . . . . . . . . . . 89

Blanco . . . . . . . . . . . . . . . . . . . . . 90

Bosque . . . . . . . . . . . . . . . . . . . . . 90 90

Bowie . . . . . . . . . . . . . . . . . . . . . 90

Brazoria . . . . . . . . . . . . . . . . . . . . 91

Brazos ............................. . . . . 91

Brewster ........................... . . 91

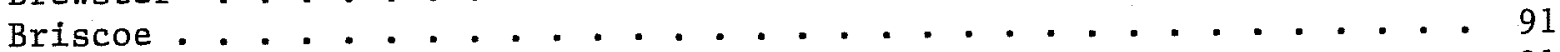

Brooks .. . . . . . . . . . . . . . . . . . . . 91

Caldwell . . . . . . . . . . . . . . . . . . . . . 91

Calhoun .. . . . . . . . . . . . . . . . . . . . 91

Cameron . . . . . . . . . . . . . . . . . . . . . 92

Cass . . . . . . . . . . . . . . . . . . . . 92

Chambers . . . . . . . . . . . . . . . . . . . 92

Cherokee . . . . . . . . . . . . . . . . . . . . 92

Clay ............................. . . 92

Coleman . . . . . . . . . . . . . . . . . . . . 93

Collin . . . . . . . . . . . . . . . . . . . . . . 93

Colorado . . . . . . . . . . . . . . . . . . . . . 93

Comal . . . . . . . . . . . . . . . . . . . . . . 93

Concho . . . . . . . . . . . . . . . . . . . . . 93

Crockett . . . . . . . . . . . . . . . . . . . . . 93

Crosby . . . . . . . . . . . . . . . . . . . . . . 93

Dallas ............................ . . . . 93

Dawson . . . . . . . . . . . . . . . . . . . . 94

Denton . . . . . . . . . . . . . . . . . . . . 94

DeWitt . . . . . . . . . . . . . . . . . . . . 94

Dickens . . . . . . . . . . . . . . . . . . . . 94

Dimmit . . . . . . . . . . . . . . . . . . . 94

Duval . . . . . . . . . . . . . . . . . . . . 94

Edwards... . . . . . . . . . . . . . . . . . . 94

E1 Paso... . . . . . . . . . . . . . . . . . . 94

F11is.............................. . 95

Fannin . . . . . . . . . . . . ........... 95

Fayette . . . . . . . . . . . . . . . . 95

Fisher . . . . . . . . . . . . . . . . . . 95 


\section{COUNTY (continued)}

Floyd . . . . . . . . . . . . . . . . . . . . . 95

Fort Bend . . . . . . . . . . . . . . . . . . . . . . . 95

Freestone . . . . . . . . . . . . . . . . . . . . . 95

Frio . . . . . . . . . . . . . . . . . . . . . . . 96

Galveston . . . . . . . . . . . . . . . . . . . 96

Garza . . . . . . . . . . . . . . . . . . . . . . . 96

Gillespie . . . . . . . . . . . . . . . . . . . . . 96

Goliad . . . . . . . . . . . . . . . . . . . . . . . 96

Gonzales . . . . . . . . . . . . . . . . . . . . . . 96

Grayson . . . . . . . . . . . . . . . . . . . . . . 97

Gregg . . . . . . . . . . . . . . . . . . . . . . . . 97

Grimes . . . . . . . . . . . . . . . . . . . . . . . . 97

Guadalupe . . . . . . . . . . . . . . . . . . . . . 97

Hamilton . . . . . . . . . . . . . . . . . . . . . . . 97

Harris . . . . . . . . . . . . . . . . . . . . 97

Harrison . . . . . . . . . . . . . . . . . . . . 98

Hays . . . . . . . . . . . . . . . . . . . . . . 98

Henderson . . . . . . . . . . . . . . . . . . . . . 98

Hidalgo . . . . . . . . . . . . . . . . . . . . . . 98

Hill . . . . . . . . . . . . . . . . . . . . . 98

Hockley .. . . . . . . . . . . . . . . . . . . . 99

Hood . . . . . . . . . . . . . . . . . . . . . 99

Houston . . . . . . . . . . . . . . . . . . . . . . 99

Hudspeth . . . . . . . . . . . . . . . . . . . . 99

Hutchinson . . . . . . . . . . . . . . . . . . . 99

Jack . . . . . . . . . . . . . . . . . . . . . 99

Jackson . . . . . . . . . . . . . . . . . . . . . 99

Jasper . . . . . . . . . . . . . . . . . . . . . 100

Jeff Davis . . . . . . . . . . . . . . . . . . . 100

Jefferson . . . . . . . . . . . . . . . . . . . . . 100

Jim Hogg . . . . . . . . . . . . . . . . . . . . . . 100

Jim Wells . . . . . . . . . . . . . . . . . . . . . 100

Johnson . . . . . . . . . . . . . . . . . . . . . . 100

Karnes .. . . . . . . . . . . . . . . . . . . 100

Kaufman . . . . . . . . . . . . . . . . . . . . . 100

Kendall . . . . . . . . . . . . . . . . . . . . 100

Kenedy . . . . . . . . . . . . . . . . . . . . 100

Kent . . . . . . . . . . . . . . . . . . . . 101

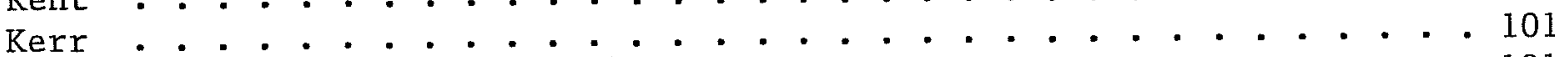

King . . . . . . . . . . . . . . . . . . . . 101

Kinney . . . . . . . . . . . . . . . . . . . . . 101

Kleberg . . . . . . . . . . . . . . . . . . . . . 101

Knox . . . . . . . . . . . . . . . . . . . . 101

Lamar . . . . . . . . . . . . . . . . . . . . 101

Lamb . . . . . . . . . . . . . . . . .... . 101

Lavaca . . . . . . . . . . . . . . . . . . . 101

Lee . . . . . . . . . . . . . . . . . . . . 101

Leon . . . . . . . . . . . . . . . . . . . . 102

Liberty . . . . . . . . . . . . . . . . . . . . . 102

Limestone . . . . . . . . . . . . . . . . . . . . 102

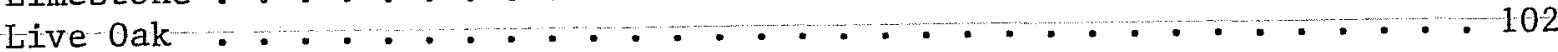




\section{COUNTY (continued)}

Llano

Lubbock

McLennan

McMullen

Madison

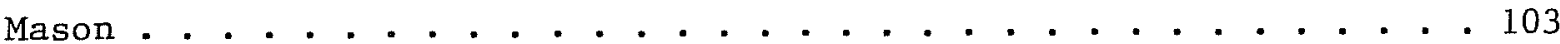

Matagorda . . . . . . . . . . . . . . . . . . . . . . . . . . 103

Maverick ... . . . . . . . . . . . . . . . . . . . . 103

Medina . . . . . . . . . . . . . . . . . . . . . . 104

Menard . . . . . . . . . . . . . . . . . . . . . . . 104

Midland . . . . . . . . . . . . . . . . . . . . . . . . 104

Milam . . . . . . . . . . . . . . . . . . . . . . . . . 104

Montague . . . . . . . . . . . . . . . . . . . . . . . . . 104

Montgomery . . . . . . . . . . . . . . . . . . . . . . . . 104

Moore . . . . . . . . . . . . . . . . . . . . . . . . . 104

Nacogdoches . . . . . . . . . . . . . . . . . . . . . . . . . 105

Navarro . . . . . . . . . . . . . . . . . . . . . . . . . . 105

Nueces . . . . . . . . . . . . . . . . . . . . . . . . . . 105

Oldham . . . . . . . . . . . . . . . . . . . . . . . . . . . 105

Orange . . . . . . . . . . . . . . . . . . . • . . - . . . . 105

Palo Pinto . . . . . . . . . . . . . . . . . . . . . . . . . . 105

Panola . . . . . . . . . . . . . . . . . . . . . . • . . . . 105

Parker .. . . . . . . . . . . . . . . . . . . . . . . . . 105

Pecos . . . . . . . . . . . . . . . . . . . . . . . . . . . 106

Polk . . . . . . . . . . . . . . . . . . . . . . . . . . . 106

Potter . . . . . . . . . . . . . . . . . . . . . . . . . . . 106

Presidio . . . . . . . . . . . . . . . . . . . . . . . . . . . 106

Rains . . . . . . . . . . . . . . . . . . . . . . . . . 106

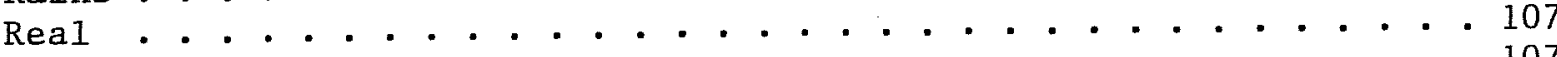

Red River . . . . . . . . . . . . . . . . . . . . . . . . . 107

Reeves . . . . . . . . . . . . . . . . . . . . . . . . 107

Refugio . . . . . . . . . . . . . . . . . . . . . . . . . 107

Robertson . . . . . . . . . . . . . . . . . . . . . . . . 107

Runnels . . . . . . . . . . . . . . . . . . . . . . . . 107

Rusk . . . . . . . . . . . . . . . . . . . . . . . . . . . 107

Sabine . . . . . . . . . . . . . . . . . . . . . . . . . . 107

San Augustine . . . . . . . . . . . . . . . . . . . . . . . . . 107

San Jacinto . . . . . . . . . . . . . . . . . . . . . . . . . . 108

San Patricio . . . . . . . . . . . . . . . . . . . . . . . . . 108

San Saba . . . . . . . . . . . . . . . . . . . . . . . . . . . 108

Scurry . . . . . . . . . . . . . . . . . . . . . . . . . . . 108

Shackelford . . . . . . . . . . . . . . . . . . . . . . . . 108

Shelby . . . . . . . . . . . . . . . . . . . . . . . . . . 108

Smith . . . . . . . . . . . . . . . . . . . . . . . . . . 108

Starr . . . . . . . . . . . . . . . . . . . . . . . . . . . 108

Stephens •. . . . . . . . . . . . . . . . . . . . . . . . . 108

Stonewal1 . • . . . . . . . . . . . . . . . . . . . . . . . . 108

Tarrant . . . . . . . . . . . . . . . . . . . . . . . . . . 109

Terrel1 . . . . . . . . . . . . . . . . . . . . . . . . . 109

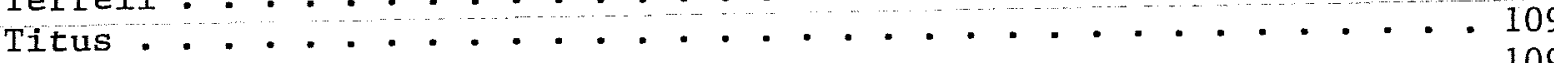

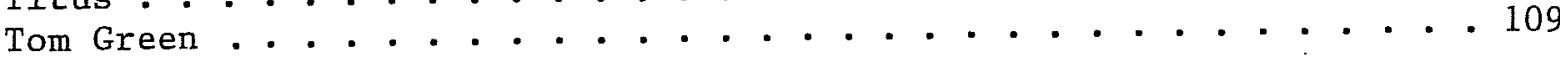




\section{COUNTY (continued)}

Travis . . . . . ..................... 109

Trinity . . . . . . . . . . . . . . . . .... 109

Uvalde . . . . . . . . . . . . . ............ 110

Val Verde ............................. . 110

Van Zandt . . . . . . . . . . ............. . 110

Victoria . . . . . . . . . . . . . . . . . . . . . 110

Walker ............................. . 110

Waller . . . . . . . . . . . . . .......... . 110

Washington .......................... 110

Webb................................ . 111

Wharton ............................ . . 111

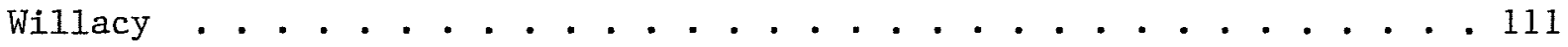

Williamson . . . . . . . . . . . . . . . . . . . . 111

Wilson . . . . . . . . . . . . . . . . . . . . . . 111

Wise .. . . . . . . . . . . . . . . . . . . . . . . . 111

Yoakum . . . . . . . . . . . . . . . . . . . . 112

Zapata.............................. 112

Zavala.......................... . . 112

NO COUNTIES MENTIONED . . . . . . . . . . . . . . . . . . . . 112

STATEWIDE/REGIONAL SYNTHESES . . . . . . . . . . . . . . . . . . 112 


\section{ACKNOWLEDGMENTS}

A number of people have given their assistance in this project. Without their generous help this bibliography would have been impossible to complete. It is our desire to acknowledge everyone who aided in this project. Any omissions are not intentional.

All major state agencies dealing with archaeology were contacted during this study and the personnel we interacted with were, without exception, very helpful. The following agencies deserve our deep appreciation: Office of the State Archeologist, Texas Historical Commission - Robert J. Mallouf, Wayne R. Roberson, Helen Simons, and Paul J. White; Texas Archeological Research Laboratory - Carolyn. Spock and Dee Ann Story; Texas Archeological Survey Solveig Turpin, Jack Jackson, Hank Moncure, and Bruce Nightengale; Texas Department of Water Resources - Daniel E. Fox; State Department of Highways and Public Transportation - Frank A. Weir and John W. Clark, Jx., and Texas Antiquities Committee - J. Barto Arnold.

Several contract archaeology firms were most helpful. Acknowledged are Espey, Huston and Associates, Inc. - Clell L. Bond, Wayne P. Glander, Leonard R. Voellinger, and Melissa W. Voellinger; Heartfield, Price and Greene, Inc. Lorraine Heartfield, G. R. Dennis Price, and Glen Greene; Lone Star Archeological Services, Inc. - Alton Briggs; and Prewitt and Associates, Inc.

- Elton R. Prewitt.

This project could not have been completed without the support of the Center for Archaeological Research, The University of Texas at San Antonio - Thomas R. Hester, Jack D. Eaton, Anne A. Fox, and Sharon Quirk - and the Archeological Research Laboratory, Texas A\&M University - David L. Carlson, Shawn Bonath Carlson, and Erwin Roemer.

Three individuals deserve recognition for the amount of personal time they gave to this project. Michael $R$. Bradle spent long hours with the boring tasks of checking for typographical errors and cross-checking new manuscripts against old drafts. Mrs. Inus Marie Harris devoted much time to tracking down reports written by her late husband, R. K. Harris and obtaining information in The Record, a journal of which we were unable to get many copies. Celinda Stevens patiently helped with the printing of the manuscript and lent her knowledge of word processing.

Other individuals we would like to acknowledge "are: Georgia Blake of the El Paso Archaeological Society; Alan R. Duke of the Houston Archeological Society; Billy R. Harrison, Curator of Anthropology, The Panhandle-Plains Historical Museum; Herbert C. Morrow, Consultant, Albert J. Redder of the Central Texas Archeological Society; and Aaron D. Riggs of the Midland Archeological Society.

Special acknowledgments are given to Eleanor Ann Moore and Guusje Zimmerman Moore for their patience and understanding throughout this project. 


\section{INTRODUCTION}

The idea for compiling a bibliography of works dealing with historical archaeology in Texas originated while William Moore was enrolled in Donny Hamilton's course in Historical Archaeology at Texas A\&M University in 1978. The paper he turned in for a grade in Dr. Hamilton's course contained only major works in the bibliography. Although it was annotated in some detail, it was not very complete. At that time Mr. Moore was not aware of the vast amount of reports dealing with historical archaeology in the state.

Mr. Moore gave a copy of his original manuscript to the Texas Archeological Research Laboratory in Austin, Texas, for their files and received encouragement from Dr. Dee Ann Story to continue with the project, making it more comprehensive. After working on the manuscript for some time, he realized the need for assistance and solicited Roger Moore to aid in the project. The finished manuscript is the product of years of cooperation between the two as well as numerous others in the discipline. Most of the work was carried out on weekends and after normal working hours except for a few visits to various agencies to look at reports and talk to individuals.

We hope that this bibliography will be a useful tool for researchers interested in historic archaeology in Texas. We were not able to check every report and journal as many were not available or located in places too distant to travel. We would, therefore, greatly appreciate hearing from anyone who can provide information on additional references that we omitted as well as corrections for any mistakes in this bibliography. This information will be incorporated into a revised edition of this manuscript. It is the purpose of this bibliography to provide the researcher with a comprehensive listing of references pertaining to historical archaeology in Texas.

One of the major problems of this project was deciding which references to omit. There is no problem with those reports which deal exclusively with excavations at Spanish missions or nineteenth century forts. However, there are numerous contract reports which document only a few trash scatters or maybe an isolated cistern. Should these be considered significant? We believe so. It is our intention to include as many references to historic sites as possible. As mentioned above, we were not able to review every issue of certain journals or complete series of reports published by some agencies. We do not want the reader to think when encountering each reference that every volume by the various titles in the bibliography was checked. Major journals and report series that we were not able to check thoroughly include The Artifact, The Record, journals and newsletters of the Society for Historical Archaeology, and reports published by the Archaeological Research Program, Southern Methodist University. 
Arkansas Archeological Survey. Research Series

AAS-RS

Central Texas Archeological Society Bulletin

CTAS

$\because \div$

iti...

GTAS-N Newsletter

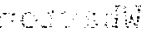

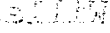

BTAPS

Paleontological Society.

BTAS

Bulletin of the Texas Archeological Society.

Espey, Huston and Associates, Inc.

EHA :

Historical Archaeology: Journal of the Society for Historical Archaeology

SHA-J

Houston Archeological Society. Journal

HAS -J

Houston Archeological Society Newsletter

HAS - N

Office of the State Archeologist - Texas

Historical Commission

THC

Office of the State Archeologist - Texas Historical Commission, Archeological

Survey Report

THC-ASR

Office of the State Archeologist - Texas

Historical Commission, Report

THC-R

Office of the State Archeologist - Texas Historical Commission, Special Report

THC-SR

Prewitt and Associates, Inc., Reports of Investigations

PA-RI

Southern Methodist University

SMU

Southern Methodist University, Archaeology

Research Program, Archaeological

Monographs

SMU-AM 
Southern Methodist University, Archaeology Research Program, Contributions in Anthropology

SMU-CA

Southern Methodist University, Archaeology Research Program, Research Report

SMU-RR

State Building Commission, Archeological Program Report

SBC - APR

State Department of Highways and Public Transportation, Highway Design Division, Publications in Archaeology

SHDPT

Stephen F. Austin State University SFA

Stephen F. Austin State University, Papers in Anthropology

SFA-PA

Texas A\&M University

TAMU

Texas A\&M University, Anthropology

Laboratory Report

TAMU-ALR

Texas A\&M University, Archeological Research Laboratory, Archeological Surveys

TAMU -AS

Texas A\&M University, Archeological Research Laboratory, Archeological Survey Report

TAMU - ASR

Texas A\&M University, Archeological Research Laboratory, Reports of Investigations

TAMU-RI

Texas A\&M University, Cultural Resources Laboratory Report

TAMU-CRL

Texas Antiquities Committee Publication

TAC - P

Texas Archeological Research Laboratory

TARL

Texas Archeological Salvage Project

TASP

Texas Archeological Salvage Project, Research Report

TASP-RR

Texas Archeological Salvage Project, Special Report

TASP - SR

Texas Archeological Survey

TAS

Texas Archeological Survey, Program Report 
Texas Archeological Survey, Research Report

TAS - RR

Texas Archeological Survey, Technical Bulletin

TAS - TB

Texas Historical Survey Committee, Archeological Report

THSC - AR

Texas Journal of Science

TJS

Texas Parks and Wildlife Department, Parks Division, Historic Sites and Restoration Branch

TPWD

Texas Parks and Wildlife Department, Parks Division, Historic Sites and Restoration Branch, Archeological Report

TPWD-AR

The University of Texas at E1 Paso, Publications in Archeology

UTEP-PA

The University of Texas at San Antonio, Center for Archaeological Research

UTSA

The University of Texas at San Antonio, Center for Archaeological Research, Archaeological Survey Report

UTSA-ASR

The University of Texas at San Antonio, Center for Archaeological Research, Choke Canyon Series

UTSA-CCS

The University of Texas at San Antonio, Center for Archaeological Research, Regional Report

UTSA-RR

The University of Texas at San Antonio, Center for Archaeological Research, Regional Studies

UTSA-RS

The University of Texas at San Antonio, Center for Archaeological Research, Special Reports

UTSA-SR 


\section{AUTHOR}

Anderson, Texas

1980 Ceramic Analysis of a Late 19th Century Trash Midden: Nottingham, Texas. HAS-N 66:10-16. (Galveston County)

1981 Status Report on Ashton Villa Research. HAS-N 69:1. (Galveston County)

1983 The Urban Residence: Archeology Explores Victorian Domestic Life. In Texana III: The Victorian Era - Texas Gomes of Age, Kirsten Mullen, editor, pp. 47-52. THC. (Galveston County)

Arnold; J. Barto III

1974 A Magnetometer Survey of the Nineteenth-Century Steamboat Black Cloud. BTAS 45:225-230. (Liberty County)

1976 An Underwater Magnetometer Survey and Site Test Excavation Project off Padre Island, Texas. TAC-P 3. (Cameron, Kenedy, and Willacy Counties)

1977 Underwater Site Test Excavations off Padre Island, Texas. TAG-P 5. (Cameron, Kenedy, and Willacy Counties)

1982 A Matagorda Bay Magnetometer Survey and Site Excavation Project. TAG-P 8. (Calhoun and Matagorda Counties)

Arnold, J. Barto III and Carl J. Clausen

1975 A Magnetometer Survey with Electronic Positioning Control and Calculator-Plotter System. SHA-J 9:26-40. (Cameron, Kenedy, and Willacy Counties)

Arnold, J. Barto III and Robert S. Weddle

1979 The Nautical Archeology of Padre Island: The Spanish Shipwrecks of 1554. TAC-P 7. (Cameron, Kenedy, and Willacy Counties)

Assad, Cristi

1978 Archaeological Investigations of Portions of the San Pedro and Alazan Acequias in San Antonio, Texas. UTSA-ASR 49. (Bexar County)

Aten, Lawrence E.

1983 Indians of the Upper Texas Coast. . Academic Press, New York. (Regional Synthesis)

Bandy, Philip A.

1981 Historical Resources of the Choke Canyon Reservoir Area in McMullen and Live Oak Counties, Texas (Part II). UTSA-GCS 2:67-190. Report prepared by the Cultural Resources Institute, Texas Tech University. (Live Oak and McMullen Counties) 
Baskin, Barbara $\mathrm{J}$.

1976a An Archeological Reconnaissance in the Bofecillos Mountains, Presidio County, Texas. In Bofecillos Mountains, A Natural Area Survey 12, Griffin Smith, editor, pp. 149-176. Published by the Lyndon B. Johnson School of Public Affairs, The University of Texas at Austin. (Presidio County)

1976b Archeological Reconnaissance of Colorado Canyon Area. In Golorado Canyon, A Natural Area Survey 11, Griffin Smith, editor, pp. 117-142. Published by the Lyndon B. Johnson School of Public Affairs, The University of Texas at Austin. (Presidio County)

Bastian, Tyler

1967 Native-Made Artifacts from Historic Sites. In A Pilot Study of Wichita Indian Archaeology and Ethnohistory, Robert E. Bell, Edward B. Jelks, and W. W. Newcomb, Jr., assemblers, pp. 184-196. National Science Foundation Report, Grant GS-964, Washington, D.C. On file at TARL. (Lamar and Montague Counties)

Baxter, Edward P. and K. L. Killen

1976 A Study of the Palo Alto Battleground, Cameron County, Texas. TAMU-ALR 33. (Cameron County)

Be11, Klein, and Hoffman

1980 Fort Concho National Historic Landmark, San Angelo, Texas: A Masterplan for Development. Report prepared by Bell, Klein, and Hoffman, Architects and Restoration Consultants, Inc., for the City of San Angelo, Texas. (Tom Green County)

Bell, Robert E., Edward B. Jelks, and W. W. Newcomb, Jr. (assemblers)

1967 A Pilot Study of Wichita Indian Archaeology and Ethnohistory. National Science Foundation Report, Grant GS-964, Washington, D.C. On file at TARL. (McLennan and Montague Counties)

Bennett, R. A.

1968 Dawson County Historical Burial. In Transactions of the Fourth Regional Archeological Symposium for Southeastern New Mexico and Western Texas, pp. 78-78a. Published by the Iraan Archeological Society. (Dawson County)

Betancourt, Julio and Warren M. Lynn

1977 An Archeological Survey of a Proposed Lignite Mine Area, Shell Rockdale South Lease, Milam County, Texas. THC-ASR 2l. (Milam County)

Black, Art

1974 Fort Lancaster State Historic Site, Crockett County, Texas, Archeological Investigations. TPWD-AR 18. (Crockett County) 
Black, Art (continued)

1980 Investigations at the Horse Trainer's Cabin (41 TV 307), McKinney Falls State Park. Appendix $C$ in Archeological Investigations at the Thomas F. McKinney Homestead, Travis County, Texas: An Experiment in Historical Archeology Part I, by Michael McEachern and Ronald W. Ralph. BTAS 51:140-145 (Travis County)

1981 Archeological Testing at Sam Bell Maxey State Historic Structure, Paris, Lamar County, Texas. TPWD. (Lamar County)

Black, Art, R. E. Burnett, and J. David Ing

1978 Magoffin Home State Historic Site, E1 Paso, Texas (41EP293):

Archeological Testing. TPWD. (E1 Paso County)

Black, Art and J. David Ing

1980 Fort McKavett State Historic Site, Menard County, Texas:

Archeological Investigations, 1974-1977. TPWD. (Menard County)

Blaine, Jay C.

1967 Guns. In A Pilot Study of Wichita Indian Archaeology and Ethnohistory, Robert E. Be11, Edward B. Jelks, and W. W. Newcomb, Jr., assemblers, pp. 163-179. National Science Foundation Report, Grant GS-964, Washington, D. C. On file at TARL. (Montague County)

Blaine, Jay C. and R. King Harris

1966 European Trade Goods: Guns. In The Gilbert Site: A Norteño Focus Site in Northeastern Texas, Edward B. Jelks, editor. BTAS $37: 33-86$. (Rains County)

Boggs, W.

n.d. Brazos Santiago Depot Archeological District (41CF4), Cameron County, Texas, 1980 Investigations. Notes on file at THC. (Cameron County)

Boice, Nancy

1980 Cistern One Glass. Appendix G in Archeological Investigations at the Thomas F. McKinney Homestead, Travis County, Texas: An Experiment in Historical Archeology Part I, by Michael McEachern and Ronald W. Ralph. BTAS 51:168-208. (Travis County)

Bond, Clell L.

1979 Palo Alto Battlefield: A Magnetometer and Metal Detector Survey. TAMU-GRL 4. (Cameron County)

1980 Summary Report: Cultura1 Resources Survey of Portions of the Village Bend Pumped Storage Project. TAMU-CRL. (Palo Pinto County)

Bond, Clell L., Wayne P. Glander, and Cynthia Brandimarte

1984 Cultural Resources of the Proposed Walker County Project. EHA, Document 83260. (Walker County) 
Bousman, C. B.

1974 Archaeological Assessment of Lake Meredith Recreation Area. SMU. (Hutchinson, Moore, and Potter Counties)

Boyd, Douglas K.

1982 A 1724 Spanish Sword from the Southern Llano Estacado. In Transactions of the 17th Regional Archeological Symposium for Southeastern New Mexico and Western Texas, Jim Cozzourt, editor, Pp. 147-152. Published by the Panhandle Archeological Society. (Hockley County)

Brackner, Joe, Jr.

1982 The Transition from Slave Potter to Free Potter: The Wilson Potteries of Guadalupe County, Texas. In Texana II: Cultural Heritage of the Plantation South, Candace Volz, editor, pp. 39-44. THC. (Guadalupe Gounty)

Brandimarte, Cynthia

1982 Archival Search for the Lorenzo de Zavala Homesite. EHA, Document 82518. (Harris County)

Briggs, Alton $\mathrm{K}$.

1971 Archeological Resources in the Texas Coastal Lowlands and Littoral. Texas Historical Survey Commission and Texas Water Development Board, Special Report 5. (Aransas, Austin, Bee, Brazoria, Calhoun, Cameron, Chambers, Goliad, Live Oak, McMullen, Nueces, Victoria, and Wharton Counties)

1974 The Archeology of 1882 Labor Camps on the Southern Pacific Railroad, Val Verde County, Texas. Unpublished M.A. thesis, The University of Texas at Austin. (Val Verde County)

1981 Archeological Investigations at the Grant Building and Plaza: Monitoring and Emergency Recovery in and Near the Sixth Street Historic District, Austin, Travis County, Texas. Lone Star Archeological Services, Report 1. (Travis County)

1983 Cultural Property Assessment of West San Bernard Station, An Ordnance Depot of the Army of the Republic of Texas, Wharton County, Texas. HAS-J 75:5-10. (Wharton County)

Brooks, Roy and Barbara J. Baskin

1976 Archeological Investigations of the Barn at the Admiral Nimitz Center, Fredericksburg, Texas. THG-SR 19. (Gillespie County)

Brown, Kenneth L., Randolph Widmer, Marylinda Govaars, and Rikkii Rubenstein 1985 Urban Archaeology and History in a Twilight Zone: 13 Blocks on the Edge of Downtown Houston, Texas. HAS-J 82:16-21. (Harris County)

Brown, Kenneth $M$.

1977 Archeological Testing at the Caswell House, Austin, Texas. TAS-TB 14. (Travis County) 
Brown, Kenneth M., Daniel R. Potter, Grant D. Hall, and Stephen L. Black 1982 Excavations at 41 LK 67, A Prehistoric Site in the Choke Canyon Reservoir, South Texas. UTSA-CCS 7. (Live Oak County)

Burnett, R. E.

1981 Archeological Testing, Fanthorp Inn State Historic Site, 41GM79, Grimes County, Texas. TPWD. (Grimes County)

Campbe11, Thomas $\mathrm{N}$.

1956 Archeological Investigations at the Caplin Site, Galveston County, Texas. TJS 9(4):448-471. (Galveston County)

Campbe11, T. N. and T. J. Campbel1

1981 Historic Indian Groups of the Choke Canyon Reservoir and Surrounding Area, Southern Texas. UTSA-CCS 1. (Bee, Live Oak, and McMullen Counties; Regional Synthesis)

1985 Indian Groups Associated with Spanish Missions of the San Antonio Missions National Historical Park. UTSA-SR 16. (Bexar County)

Carlson, Shawn Bonath

1983 Archeological and Historical Investigations at the Richard Carter Site (41BZ74), Brazos County, Texas. TAMU-RI 2. (Brazos County)

1984 Ethnoarchaeological Studies at a 20th Century Rural Farmstead in Central Texas: The W. Jarvis Henderson Site (41BL273). Fort Hood Archaeological Resource Management Series: Research Report 12. (Be11 County)

Carlson, Shawn Bonath, Cristi Assad, Erwin Roemer, Jr., and David L. Carlson 1983 Archeological and Historic Investigations in Milam County, Texas. TAMU-AS 1. (Milam County)

Carter, E. Suzanne

1974 Fort McKavett, Menard County, Texas: Archeological and Architectural Details of the Bakery, Barracks and Headquarters Buildings, Spring 1973. TAS-RR 20. (Menard County)

Carter, E. Suzanne and Crystal S. Ragsdale

1976 Biegel Settlement: Historic Sites Research, Fayette Power Project, Fayette County, Texas. TAS-RR 59. (Fayette County)

Carter, Susan A.

1973 Archeological Investigations at the Johnson Brothers Cattle Company Ranch Headquarters, Lyndon B. Johnson National Historical Site, Blanco County, Texas. TAS-RR 27. (Blanco County)

Cartier, Robert R. and Frank Hole

1972a Brick-Making on Cedar Bayou. Appendix II in San Jacinto

Battleground: Archeological Studies, 1971-1972. Report prepared by the Department of Anthropology, Rice University. On file at THC. (Harris County) 
Cartier, Robert $R$. and Frank Hole (continued)

$1972 \mathrm{~b}$ History of the McCormick League and Areas Adjoining the San Jacinto Battleground. Part 1 of San Jacinto Battleground: Archeological Studies, 1971-1972. Report prepared by the Department of Anthropology, Rice University. On file at THC. (Harris County)

Chaffin-Lohse, Margie

1978 A Cultural Resource Survey of the Luce Bayou Diversion Project, Liberty County, Texas. Report prepared for Brown and Root Engineering, Houston, Texas. On file at THC. (Liberty County)

Clark, John W., Jr.

1972 Archeological Investigations at Fort Lancaster State Historic Site, Crockett County, Texas. TASP-RR 12. (Crockett County)

1974a Archeological Investigations at Ursuline Academy, San Antonio, Texas, June 1974. THC-SR 16. (Bexar County)

1974b Preliminary Archeological Investigations at Wulff House, San Antonio, Texas. THG-SR 14. (Bexar County)

1976 The Sugar Industry at Mission San Jose y San Miguel de Aguayo. BTAS 47:245-260. (Bexar County)

1978 Mission San José y San Miguel de Aguayo: Archeological Investigations, December 1974. THC-R 29. (Bexar County)

1980a Sa Reina Norteña: History and Archeology of San José Mission. La Tierra 7(1):3-15. (Bexar County)

1980b The Woodlands: Archeological Investigations at the Sam Houston Home, Huntsville, Walker County, Texas. PA-RI 4. (Walker County)

1984 Archaeological Test Excavations at an Early Twentieth Century Dump in North San Antonio, Bexar County, Texas. SSDPT:26. (Bexar County)

Clark, John W., Jr. and James E. Ivey

1974 Archeological and Historical Investigations at Martin Lake, Rusk and Panola Counties, Texas. TAS-RR 32. (Panola and Rusk Counties)

Clark, John W., Jr. and Elton R. Prewitt

1979 Archeological Test Excavations in Areas to be Affected by a Proposed French Drain West of the Granary Mission San José State Historic Site (41BX3), Bexar County, Texas. PA-RI 3. (Bexar County)

Cliff, Maynard, Carol Carter, and Linda Verrett 1974 Archaeological Survey of the Welsh Power Plant. SMU-RR 33. (Titus County) 
Coffman, D. and D. Ground

1970 Excavation: Post Surgeon Quarters: Coffman-Ground Report.

Unpublished manuscript on file in the Fort Concho Museum Library, San Angelo, Texas. (Tom Green County)

Coffman, Robert $J$. and Martha Doty Freeman

1985 Inventory and Assessment of Cultural Resources at the Meadows at Chandler Creek Municipal Utility District No. 1, Williamson County, Texas. PA-RI 41. (Williamson County)

Coleman, Roger E., Shawn B. Carlson, and David L. Carlson

1984 An Archeological Reconnaissance in Selected Areas of Western Shelby County, Texas. TAMU-AS 3. (Shelby County)

Collett, James

1984 Meyer's Springs: Forgotten Crossroads. In Transactions of the 19 th Regional Archeological Symposium for Southeastern New Mexico and Western Texas, pp. 75-89. Published by the Iraan Archeological Society. (Terrell County)

Comstock, Douglas B., Kerry A. Grombacher, and David S. Dibble

1973 A Study of the Effects of Shell Dredging on the Archeological and Historical Resources of San Antonio Bay. TAS-RR 23. (Calhoun and Refugio Counties)

Conger, Rodger N.

1953 Iron Trade Hatchets in Central Texas. CTAS 6:86-87. (Stephens County)

Cook, P. J.

1980 A Review of the History and Archaeology of Mission Concepción. La Tierra 7(3):3-16. (Bexar County)

1981 A Review of the History and Archaeology of San Lorenzo, Real County, Southern Texas. La Tierra 8(3):3-15. (Real County)

Corbin, James E., Arlan Kalina, and Thomas C. Alex

1980 Mission Dolores de los Ais: Archaeological Investigations at an Early Spanish Colonial Mission, San Augustine County, Texas.

SFA-PA 2. (San Augustine County)

Corbin, James E. and Deborah C. Kisling

1983 The Adolphus Sterne Home: Preliminary Archaeological Investigations of a Mid-Nineteenth Century Plantation in Nacogdoches County, Texas. SFA-PA 4. (Nacogdoches County)

Crosby, H. Anthony

1977 Architecture of Texana, 1831-1882, Jackson County, Texas. TAS-RR 57. (Jackson County) 
Crouch, D. J.

1982 Varner-Hogg Plantation State Historical Park, Brazoria County, Texas, Archeological Investigations, 1979-1981. TPWD. (Brazoria County)

Davis, E. Mott

1970 Part II - Texas [Historic Period]. In Archeological and Historical Resources of the Red River Basin, Hester A. Davis, editor, pp. 52-58. AAS-RS 1. (Regional Synthesis)

Davis, E. Mott, Kathleen Gilmore, Loyd Harper, R. King Harris, Edward B.

Jelks, and Bill Yancy

1966 The Site. In The Gilbert Site: A Norteño Focus Site in

Northeastern Texas, E. B. Jelks, editor. BTAS 37:1-17. (Rains County)

Davis, E. Mott and. James E. Corbin

1967 Archeological Investigations at Washington-on-the-Brazos State

Park in 1966. SBC-APR 5. (Washington County)

Davison, Claire $C$. and R. King Harris

1974 Chemical Profile of Glass Trade Beads from Archeological Sites in Texas and Oklahoma. BTAS 45:209-218. (Lamar, Limestone, Montague, and Rains Counties)

Day, D. William, Jane Laurens-Day, and.Elton R. Prewitt

1981 Cultural Resources Surveys and Assessments in Portions of Hidalgo and Willacy Counties, Texas. PA-RI 15. (Hidalgo and Willacy Counties)

Denton, Joe $\mathrm{T}$.

1983 Archaeological Testing of Site 41PK69, Polk County, Texas. SDHPT. (Polk County)

Dibble, David S. and Martha D. Freeman

1979 An Archeological and Historical Survey of Areas to be Affected by Construction of STP Modified Transmission Line Routes, Matagorda, Colorado and Fayette Counties. TAS-TB 25. (Colorado, Fayette, and Matagorda Counties)

Dibble, David S. and Jack M. Jackson

1980 A Preliminary Assessment of the Archeological and Historical Potential of a 1300-Acre Plant Site in Matagorda County, Texas. TAS-TB 43. (Matagorda County)

Dickinson, S. D.

1941 Certain Vessels from the Clements Place, An Historic Caddo Site. BTAPS $13: 117-132$. (Cass County)

Dickson, D. Bruce

1976 Archeological Research at Fort Richardson State Park, Summer 1975. TAMU-ALR 28. (Jack County) 
Doran, G. H. and R. M. Malina

1974 Skeletal Material from the Cogdell Burial in Floyd County, Texas. BTAS 46:65-67. (Floyd County)

Duffield, Lathel $F$. and Edward B. Jelks

1961 The Pearson Site: A Historic Indian Site in Iron Bridge Reservoir, Rains County, Texas. The University of Texas at Austin, Department of Anthropology, Archaeology Series 4. (Rains County)

Duke, Alan R.

1974a Another Artifact from San Jacinto. HAS-N 46:7. (Harris County)

1974b Artifacts from San Jacinto. HAS-N 45:4-7. (Harris County)

1974c A Clay Pipe from Peggy Lake. HAS-N 47:10. (Harris County)

1977a Armand Bayou Archeological Work. HAS-N 55:1-3. (Harris County)

1977b HAS Fieldwork - March 1977. HAS-N 55:4. (Harris County)

Duke, Alan R. and F. G. Muller

1980 41HR74 - A Harris County Shell Site on Lower San Jacinto Bay. HAS -N 68:24-26. (Harris County)

Durrenberger, E. Paul

1965 Anderson's Mill (41 TV 130): A Historic Site in Travis County, Texas. BTAS 36:1-69. (Travis County)

Eagleton, N. Ethie

1955 An Historic Indian Cache in Pecos County. BTAS 26:200-217. (Pecos County)

Eaton, Jack D.

1980 Excavations at the Alamo Shrine (San Antonio de Valero), 1977.

UTSA-SR 10. (Bexar County)

1981 History and Archaeology of Mission San Antonio de Valero (The Alamo). La Tierra 8(1):3-13. (Bexar County)

Ensor, Hal Blaine, Shawn Bonath Carlson, and David L. Carlson

1983 Archeological and Historic Investigations of the Harris County Lease in Barker Reservoir, Harris County, Texas. TAMU-AS 2. (Harris County)

Everett, Dianna

1981 Historical Resources of the Choke Canyon Reservoir Area in McMullen and Live Oak Counties, Texas (Part I). UTSA-CGS 2:xiii-64. Report prepared by the Cultural Resources Institute, Texas Tech University. (Live Oak and McMullen Counties) 
Fawcett, William B., Jr.

1980 Part II: Archeological Investigations at Historic Sites. In The Antebellum Period in the Stephen F. Austin Colony: Historical and Archeological Research in the Palmetto Bend Reservoir Area, Jackson County, Texas. TAS-RR 70, Palmetto Bend Reservoir Series 5. (Jackson County)

1983 The Antebellum Period in the Stephen F. Austin Colony: Historical Archaeology of the George Sutherland Plantation (41 JK 33). In Forgotten Places and Things: Archaeological Perspectives on American History, Albert E. Ward, editor, pp. 157-171. Center for Anthropological Studies, Contributions to Anthropological Studies 3 , Albuquerque. (Jackson County)

Fawcett, William B, Jr. and Paul R. McGuff

1969 The Bacon House Site: A Historic Excavation Technique Study in Northern Bexar County. John Marsha11 High School Archaeology Glub Bulletin 1. (Bexar County)

Ferring, C. Reid

1983 Nineteenth-Century Archeology at Lakeview Reservoir, Texas. In Texana I: The Frontier, LeRoy Johnson, Jr., editor, pp. 73-76. THC. (Dallas, Ellis, and Tarrant Counties)

Ferring, C. Reid and Nancy G. Reese

1982 Part II: Historical Archaeology. In Archaeological Investigations at Lakeview Lake: 1979 and 1980, L. Mark Rabb, Principal Investigator, pp. 109-233. SMU-AM 2. (Dallas, E11is, and Tarrant Counties)

Few, Joan

1982 Glorianna Homestead, 41JP94. HAS-J 74:17-21. (Jasper County)

Fields, Ross

1984 Archeological Investigations at 41LN134 and 41LN144, Jewett

Mine Project, Leon County, Texas. PA-RI 35. (Leon County)

Fields, Ross C., Martha Doty Freeman, and Steven M. Kotter

1983 Inventory and Assessment of Cultural Resources at Addicks

Reservoir, Harris County, Texas. PA-RI 22. (Harris County)

Fields, Ross C. and Jack M. Jackson

1984 Archeological and Historical Investigations at $41 \mathrm{GV} 14$ and 41GV15, Galveston, County, Texas. PA-RI 34. (Galveston Gounty)

Fields, Ross C. and Nancy Reese

1984 Archeological and Historical Investigations at the Lost Lake Disposal Area, Harris County, Texas. PA-RI 29. (Harris County)

Fox, Anne A.

1973 Archeological Investigations at Fort Griffin State Historical Park, Texas. TAS-RR 21. (Shackelford County) 
Fox, Anne A. (continued)

1976 Archaeological Investigations at Fort Griffin State Historical Park, Shackelford County, Texas. UTSA-ASR 23. (Shackelford County)

1977 The Archaeology and History of the Spanish Governor's Palace Park. UTSA-ASR 31. (Bexar County)

1978 Archaeological Investigations of Portions of the San Pedro and Alazan Acequias in San Antonio, Texas. UTSA-ASR 49. (Bexar County)

1979a Archaeological and Historical Investigations at 41 BX 180, Walker Ranch, San Antonio, Texas: Phase I. UTSA-ASR 83: (Bexar County)

1979b Preliminary Report of Archaeological Testing at the Tonkawa Bluff, Victoria Gity Park, Victoria Texas. UTSA-ASR 70. (Victoria County)

1979c A Survey of Archaeological, Architectural, and Historical Sites on the San Antonio River from Olmos Dam to South Alamo Street and on San Pedro Creek from San Pedro Park to Guadalupe Street. UTSA-ASR 80. (Bexar County)

1981 Test Excavations at Mission San Francisco de 1a Espada. UTSA-ASR 108. (Bexar County)

1983 The Archeology of Spanish Sites. In Texana I: The Frontier, LeRoy Johnson, Jr., editor, pp. 21-24. THC. (Bexar County)

1984 A Study of Five Historic Cemeteries at Choke Canyon Reservoir, Live Oak and McMullen Counties, Texas. UTSA-GGS 9. (Live Oak and McMullen Counties)

1985 Testing for the Location of the Alamo Acequia (41 BX 8) at HemisFair Plaza, San Antonio, Texas. UTSA-ASR 142. (Bexar County)

1986 Archaeological Investigations at Historic Sites in the Choke Canyon Reservoir, Southern Texas. UTSA-CCS 12. (Live Oak and McMullen Counties)

n.d.a Archaeological Investigations at Mission Concepción and Mission Parkway, Part II: Mission Parkway Survey. UTSA-ASR 114 (contact UTSA for information). (Bexar County)

n.d.b The Blue Wing Road Burial (41 BX 34). Field notes on file at UTSA. (Bexar County)

Fox, Anne A., Ferris A. Bass, Jr., and Thomas R. Hester

1976 The Archaeology and History of Alamo Plaza. UTSA-ASR 16. (Bexar County)

Fox, Anne A. and I. Waynne Cox

1983 Archaeological and Historical Investigations at the Valenzuela Ranch, Dimmit County, Texas. UTSA-ASR 126.-(Dimmit County) 
Fox, Anne A., William Day, and Lynn Highley

1980 Archaeological and Historical Investigations at Wallisville Lake, Chambers and Liberty Counties, Texas. UTSA-ASR 90. (Chambers and Liberty Counties)

Fox, Anne A. and Thomas R. Hester

1976 Archaeological Test Excavations at Mission San Francisco de la Espada. UTSA-ASR 22. (Bexar County)

Fox, Anne A. and C. Lynn Highley

1985 History and Archaeology of the Hot Wells Hotel Site, 41 BX 237. UTSA-ASR 152. (Bexar County)

Fox, Anne A. and James E. Ivey

1979 Historical Survey of the Lands Within the Alamo Plaza-River Linkage Development Project. UTSA-ASR 77. (Bexar County)

Fox, Anne A., James E. Ivey, and J. Carroll Markey

1981 Cultural Resource Survey, Freeport Harbor, Texas 45-Foot Navigation Improvement Project, Brazoria County, Texas. UTSA-ASR 107. (Brazoria County)

Fox, Anne A. and Katherine Livingston

1979 Historical, Architectural and Archaeological Investigations at the Steiner-Schob Complex, Victoria County, Texas. UTSA-ASR 52. (Victoria County)

Fox, Daniel E.

1970 Archeological Salvage at Mission San José, December 1969, April and August 1970. THC-SR 3. (Bexar County)

1979a Archaeological Testing at Fort McIntosh, Laredo Junior College Campus, Laredo, Texas. UTSA-ASR 68. (Webb County)

$1979 \mathrm{~b}$ The Lithic Artifacts of Indians at the Spanish Colonial Missions, San Antonio, Texas. UTSA-SR 8. (Bexar County)

1979c Preliminary Report for Waco Suspension Bridge/Indian Spring Park. Report submitted by UTSA to the Gity of Waco and the Office of the State Archeologist. (McLennan County)

1980a The Material Evidence of Texas History. BTAS 51:271-287. (Statewide Synthesis)

$1980 \mathrm{~b}$ Test Excavations at Classen Rockshelter, Northeastern Bexar County, Texas. La Tierra 7(1):16-23. (Bexar County)

1982 Excavations at Sites 41 LK $31 / 32$ and 41 LK 202 in the Choke Canyon Reservoir, South Texas. Part II: Historic Investigations. UTSA-CCS 8:91-132. (Live Oak County) 
Fox, Daniel E. (continued)

1983 Traces of Texas History: Archeological Evidence of the Past 450

Years. Corona Publishing Co., San Antonio, Texas. (Statewide Synthesis)

Fox, Daniel E. and Warren M. Lynn

1976 41MC185 - A Historic Building Site in the Proposed Choke Canyon Reservoir Area, Live Oak and McMullen Counties, Texas. La Tierra $3(2): 11-20$. (Live Oak and McMullen Counties)

Fox, Daniel E., Robert J. Mallouf, Nancy O'Malley, and William M. Sorrow 1974 Archeological Resources of the Proposed Cuero I Reservoir, DeWitt and Gonzales Counties, Texas. THC-ASR 12. (DeWitt and Gonzales Counties)

Fox, Daniel E., Dan Scurlock, and John W. Clark, Jr.

1977 Archeological Investigations at San Fernando Cathedral, San Antonio, Texas: A Preliminary Report. THG-SR 22. (Bexar County)

Fox, Daniel E., Fred Valdez, Jr., and Lynn 0. Bobbitt

1978 An Archaeological Assessment of the Dolores Aldrete House Property, San Antonio, Texas. UTSA-ASR 58. (Bexar County)

Fox, Daniel E., W. Hayden Whitsett, and C. J. Jurgens

1981 An Archeological Reconnaissance at the City of Round Rock, Williams on County, Texas. Unpublished report on file at the Texas Department of Water Resources, Austin. (Williamson County)

Freeman, Martha Doty

1976 A History of the Hoxie San Gabriel Ranch: Williamson County, Texas. TAS-RR 63. (Williamson County)

1978 A Preliminary Assessment of the Historical Resources of the South Hallsville Project Area, Harrison County, Texas. EHA, Document 78102. (Harrison County)

1980 Part I: The Sutherland Plantation and the Alabama Settlement: A Study in Cluster Migration. In The Antebellum Period in the Stephen F. Austin Colony: Historical and Archeological Research in the Palmetto Bend Reservoir Area, Jackson County, Texas. TAS-RR 70, Palmetto Bend Reservoir Series 5. (Jackson County)

1983 An Assessment of the Reliability of Archeological Survey for Locating and Assessing Historic Resources. Appendix $\mathrm{V}$ in Inventory and Assessment of Cultural Resources at Addicks Reservoir, Harris County, Texas, by Ross C. Fields, Martha Doty Freeman, and Steven M. Kotter. PA-RI 22:227-232. (Harris County)

Freeman, Martha Doty and Joe C. Freeman

1981 A Cultural Resource Inventory and Assessment of the Proposed Stacy Reservoir, Concho, Coleman, and Runnels Counties, Texas, Vol. II, Historic Cultural Resources.-EHA,-Document 81052. (Coleman, Goncho, and Runnels Counties) 
Freeman, Martha Doty and Thomas H. Hale, Jr.

1978 Cypress Creek: Reconnaissance Survey and Assessment of Prehistoric and Historical Resources, Cypress Creek Watershed in Harris and Waller Counties, Texas. TAS-RR 68. (Harris and Waller Counties)

Fritz, Gayle

1975 Matagorda Bay Area, Texas: A Survey of the Archeological and Historical Resources. TAS-RR 45. (Galhoun, Jackson, and Matagorda Counties)

Frkuska, Augustine J., Jr.

1981 Archaeological Investigations at the San Pedro Acequia, San Antonio, Texas. UTSA-ASR 103. (Bexar County)

Fullen, William L.

1978 E1 Orcoquisac Archeologic District, Wallisville Reservoir, Texas: Past, Present and Future. HAS-N 59:5-12. (Chambers and Liberty Counties)

Garrison, Ervin

1983 An Archival and Instrumental Survey for the Mittie Stephens, Caddo Lake, Texas and Louisiana. Report prepared for the Mittie Stephens Foundation by the Texas A\&M University Research Foundation. (Harrison County)

Gerstle, Andrea, Thomas C. Kelly, and Cristi Assad

1978 The Fort Sam Houston Project: An Archaeological and Historical Assessment. UTSA-ASR 40. (Bexar County)

Gilmore, Kathleen

1967 A Documentary and Archeological Investigation of Presidio San Luís de las Amarillas and Mission Santa Cruz de San Sabá, Menard County, Texas: A Preliminary Report. SBG-APR 9. (Menard County)

1969 The San Xavier Missions: A Study in Historical Site Identification. SBC-APR 16. (Milam County)

1973a An Archeological Investigation at the Lyndon B. Johnson Birthplace National Historic Site, Gillespie County, Texas. TAS-RR 22. (Gillespie County)

1973b The Keeran Site: The Probable Site of La Salle's Fort St. Louis in Texas. THC-R 24. (Victoria County)

1974a Cultural Variation on the Texas Coast: Analysis of an Aboriginal Shell Midden, Wallisville Reservoir, Texas. TAS-RR 44. (Chambers County)

1974b Mission Rosario, Archeological Investigations 1973 (Part 1). TPWD-AR 14. (Goliad County)

1974c Mission Rosario, Archeological Investigations 1974 (Part 2). TPWD-AR 14. (Goliad County) 
Gilmore, Kathleen (continued)

1978 Spanish Colonial Settlements in Texas. In Texas Archeology: Essays Honoring R. King Harris, Kurt D. House, editor, pp. 132-145. SMU, Institute for the Study of Earth and Man, Report of Investigations 3. (Statewide Synthesis)

1982 So Shall Ye Reap: The San Xavier Missions. La Tierra 9(1):2-10. (Milam County)

Glander, Wayne P. and Cynthia Brandimarte

1983 Cultural Resources Survey of the Martin Lake Mine: Tracts A, B, and C, Panola County, Texas. EHA, Document 83121. (Panola County)

Glander, Wayne P. and Sally S. Victor

1984 Additional Cultural Resource Investigations: Martin Lake Mine, Tracts A, B, and C. EHA, Document 83718. (Panola County)

Granberry, Doyle S.

1977 The Gano Log Gabin Site. The Record 33(1):2-8. (Tarrant County)

Green, F. E.

1969 Report on Preliminary Archaeological Investigations at Fort McKavett, Texas. Report prepared by Texas Tech University. On file at TPWD. (Menard County)

Greer, Georgeanna H.

1983 Pioneer Texas Potteries. In Texana I: The Frontier, LeRoy Johnson, Jr., editor, pp. 63-66. THC. (Bastrop, Denton, Guadalupe, Harrison, Jackson, Montgomery, and Rusk Counties)

Greer, John W.

1967 A Description of the Stratigraphy, Features, and Artifacts from an Archeological Excavation at the Alamo. SBC-APR 3. (Bexar County)

1979 An Archeological Reconnaissance of the Enchanted Rock Area of Llano and Gillespie Counties, Central Texas. In Enchanted Rock, A Natural Area Survey 14, Griffin Smith, editor, pp. 117-166. Published by the Lyndon B. Johnson School of Public Affairs, The University of Texas at Austin. (Gillespie and Llano Counties)

Gregg, Richard L.

1980a The William Dobie Survey. HAS-N 66:22-30. (Harris County)

1980b The William Dobie Survey (Continued from HAS-N 66). HAS-N 67:9-13. (Harris County)

1981a The William Dobie Survey, Harris County, Texas (Continued). HAS-N 69:4-9. (Harris County)

1981b The William Dobie Survey, Harris County, Texas (Continued). HAS-N 70:14-17. (Harris County) 
Guderjan, T. H.

1981 Archaeological Investigations in the Forest Grove/Big Rock Areas, North-Central Texas. SMU. (Henderson and Van Zandt Counties)

Guffee, E. J.

1976a Camp Peña Colorado, Texas 1879-1893. M.A. thesis, Department of History, West Texas State University. (Brewster County)

1976b The Merrell-Taylor Village Site: An Archeological Investigation of Pre-Anglo, Spanish-Mexican Occupation on Quitaque Greek in Floyd County, Texas. Archeological Research Laboratory, Llano Estacado Museum, Wayland Baptist College, Plainview. On file at TARL. (Floyd County)

1980 The Soda Lake Ruins: An Archeological Investigation of Anglo Occupation in the Sandhills of Lamb County, Texas. Archeological Research Laboratory, Llano Estacado Museum, Wayland Baptist College, Plainview. On file at TARL. (Lamb County)

Haaskar1, Robert A., Jr.

1957 An Unusual Historic Indian House Site in Washington Gounty, Texas. BTAS 28:232-239. (Washington County)

Hal1, Grant D., Stephen L. Black, and Carol Graves

1982 Archaeological Investigations at Choke Canyon Reservoir, South Texas: The Phase I Findings. UTSA-CCS 5. (Live Oak and McMullen Counties)

Hall, Grant D. and Mary M. Ford

1974 South Texas Project: Assessment of the Archeological and Historical Resources (South Texas Nuclear Project Site), Matagorda County, Texas. A Report on the Archeological and Historical Resources. TAS-RR 38. (Matagorda County)

Hall, Grant D. and Kerry A. Grombacher

1974 An Assessment of the Archeological and Historical Resources to be Affected by the Brazos Island Waterway Project, Texas. TAS-RR 30. (Cameron County)

Hal1, Grant D., Kerry A. Grombacher, and David S. Dibble

1974 A Study of the Archeological and Historical Resources to be Affected by Proposed and Alternate Transmission Line Routes, South Texas Project. TAS-RR 39. (Bexar, Brazoria, Calhoun, Colorado, DeWitt, Gonzales, Jackson, Matagorda, Nueces, Refugio, San Patricio, and Wharton Counties)

Harper, Loyd, Ruby Harper, R. King Harris, Inus Marie Harris, Edward B. Jelks, and J. Ned Woodall

1966 European Trade Goods: Ornaments. In The Gilbert Site: A Norteño Focus Site in Northeastern Texas, Edward B. Jelks, editor. BTAS 37:87-104. (Rains County) 
Harris, Inus Marie

1966 Notes from the Ninth Caddoan Conference. The Record 22(1):2-7. (Clay County)

1967 Notes on the Thirty-Seventh Annual Meeting of the Texas Archeological Society in 1966. The Record 23(2):9-13. (Bexar and McLennan Counties)

Harris, R. King

1940 Two Indian Village Sites Near the City of Denton. The Record 2(1):5-6. (Denton County)

1946 An Interesting Copper Article from Garrett's Bluff. The Record $5(1): 7$. (Lamar County)

1951 French or Spanish, or what is it? The Record 10(1):2-3. (Dallas County)

1953a The Sam Kaufman Site, Red River County, Texas. BTAS 24:43-68. (Red River County)

1953b Two Recent Trips to Sites in Fannin and Lamar Counties. The Record 11(5):19-20. (Fannin and Lamar Counties)

1960 Club News. The Record 15(1):1. (Hill County)

1962 Another Marker on the Trail of the Norteño: A Preliminary Report on the Gilbert Site. The Record 17(1):2-9. (Rains County)

Harris, R. King and Jay C. Blaine

1966 European Trade Goods: Guns. In The Gilbert Site: A Norteño Focus Site in Northeastern Texas, Edward B. Jelks, editor. BTAS 37:33-86. (Rains County)

Harris, R. King and Inus Marie Harris

1961 Spanish Fort, A Historic Trade Site. The Record 16(1):2-5. (Montague County)

1962 A Preliminary Report on the Gilbert Site. The Record 16(1):2-9. (Rains County)

1967 Trade Beads, Projectile Points, and Knives. In A Pilot Study of Wichita Indian Archaeology and Ethnohistory, Robert E. Bell, Edward B. Jelks, and W. W. Newcomb, Jr., assemblers, pp. 129-162. National Science Foundation Report, Grant GS-964, Washington, D.C. On file at TARL. (Bowie, Hil1, Lamar, Limestone, McLennan, Montague, Nacogdoches, Palo Pinto, and Rains Counties)

1969a French Blanket-Bale Seal from the Vinson Site in Limestone County, Texas. Manuscript on file at the Department of Anthropology, The University of Texas at Austin. (Limestone County) 
Harris, R. King and Inus Marie Harris (continued)

1969b Metal Arrow Points from the Vinson Site in Limestone County, Texas. Manuscript on file at the Department of Anthropology, The University of Texas at Austin. (Limestone County)

1969c Metal Buttons from the Vinson Site in Limestone County, Texas. Manuscript on file at the Department of Anthropology, The University of Texas at Austin. (Limestone County)

1969d A Study of Trade Beads and Native-Made Beads from the Vinson Site in Limestone County, Texas. Manuscript on file at the Department of Anthropology, The University of Texas at Austin. (Limestone County)

1973 Metal. In The Keeran Site: The Probable Site of La Salle's Fort St. Louis in Texas, by Kathleen Gilmore, pp. 49-62. THG-R 24. (Victoria County)

1974a Glass Beads. In Mission Rosario, Archeological Investigations 1973, by Kathleen Gilmore, pp. 69-71. TPWD-AR 14. (Goliad County)

$1974 \mathrm{~b}$ Metal. In Mission Rosario, Archeological Investigations 1973 (Part 1), by Kathleen Gilmore, pp. 74-78. TPWD-AR 14. (Goliad County)

1975a Beads. In Mission Rosario, Archeological Investigations 1974 (Part 2), by Kathleen Gilmore, pp. 131-132. TPWD-AR 14. (Goliad County)

1975b A Preliminary Analysis of a Small Sample of Glass Trade Beads from the Floydada Country Club Site (41FL1) in Floyd County, Texas. Manuscript on file at the Department of Anthropology, The University of Texas at Austin. (Floyd County)

1978 A Study of Glass Trade Beads from the Rosebrough Lake Site in Bowie County, Texas. North Texas State University. (Bowie County)

1980 Distribution of Natchitoches Engraved Ceramics. Louisiana Archaeology 6:223-230. (Bowie, Gregg, Harrison, Lamar, Panola, Rains, Red River, and Rusk Counties).

Harris, R. King, Inus Marie Harris, and Jay C. Blaine

1974 1860's Choctaw Village on the Brazos River in Hill County, Texas. Appendix I in An Evaluation of the Archaeological Resources at Lake Whitney, Texas, S. Alan Skinner, editor. SMU-CA 14. (Hill County)

Harris, R. King, Inus Marie Harxis, Jay C. Blaine, and J. Blaine

1965 A Preliminary Archeological and Documentary Study of the Womack Site, Lamar County, Texas. BTAS 36:287-364. (Lamar County)

Harris, R. King, Inus Marie Harris, and M. P. Miroir

1980 The Atlanta Park Site in Northeastern Texas. Louisiana Archaeology $6: 231-239$. (Cass County) 
Harris, R. King, Inus Marie Harris, and J. Ned Woodall

1966 European Trade Goods: Tools. In The Gilbert Site: A Norteño Focus Site in Northeastern Texas, Edward B. Jelks, editor. BTAS 37:18-32. (Rains County)

Harris, R. King and J. L. Shiner

1973 Historic End Scrapers in the Southern Plains. The Record 29(2):1-8. (Lamar and Rains Counties)

Harris, R. King and Curtis D. Tunnell

1966 European Trade Goods: Miscellaneous European Trade Goods. In The Gilbert Site: A Norteño Focus Site in Northeastern Texas, Edward B. Jelks, editor. BTAS 37:105-111. (Rains County)

Hart, Alyce

1972 English Inscription Stone. In Transactions of the Seventh Regional Archeological Symposium for Southeastern New Mexico and Western Texas, pp. 41-45. Published by the Dawson Archeological Society. (Dawson County)

HaskelI, Helen W.

1984 Progress Report on Excavations at Sam Houston Park. HAS-J 78:5-6. (Harris County)

Haske11, Helen W. and R. J. McIntosh

1984 Excavations in the Area of the Long Row Building, Sam Houston Park, Houston, Texas. 1984 Season. Report prepared by the Anthropology Department, Rice University. (Harris County)

Hays, T. R. and Edward B. Jelks

1966 Archeological Exploration at Fort Lancaster, 1966: A Preliminary Report. SBC-APR 4. (Crockett County)

Hays, T. R. and Eugene Herrin

1970 Padre Island Project. Unpublished report to the Texas Antiquities Committee, prepared by the Institute for Underwater Research, Inc., Dallas. On file at THC. (Cameron, Kenedy, Kleberg, and Willacy Counties)

Heartfield, Price and Greene, Inc.

1980 Peddypoint Ranch House Site. Appendix A in An Archeological Survey of the Welker Unit, Cypress Creek Park System, Harris County, Texas. Report prepared by Heartfield, Price and Greene, Inc. for the Parks Planning Department, Harris County, Texas. (Harris County)

Heck, Marlene Elizabeth

1978 An Exploration of a Common Legacy: A Conference on Border Architecture. THC. (Cameron and Webb Counties)

Henderson, Jerry and John W. Clark, Jr.

1984 Test Excavations at the Acequia and Other Features at Mission San José, Bexar County, Texas. SDHPT 25. (Bexar County) 
Hester, Thomas R.

1968 Some Notes on Historic Indian Artifacts Found Near Ozona, Texas.

Newsletter, Midland Archeological Society (June), pp. 3-5.

(Crockett County)

1970 Metal Projectile Points from Southern Texas. The Record 27(2):9-11. (Dimmit and Zavala Counties)

1975 Archaeological and Historical Resources in the San Antonio, Guadalupe River Basins: A Preliminary Statement. UTSA-RS 1.

(Bandera, Bexar, Caldwell, Calhoun, Comal, DeWitt, Goliad, Gonzales, Guadalupe, Hays, Karnes, Kendal1, Kerr, Medina, Uvalde, Victoria, and Wilson Counties)

1977 The Lithic Technology of Mission Indians in Texas and Northeastern Mexico. Lithic Technology 6(1-2):9-12. (Bexar, Goliad, Milam, and Real Counties)

1978 The Archeology of the Lower Rio Grande Valley of Texas. In An Exploration of a Common Legacy: A Gonference on Border Architecture, Marlene Elizabeth Heck, Project Director: 66-81. THC. (Cameron and Webb Counties)

1979 A Preliminary Archaeological and Historical Assessment of the Proposed Tenneco Pipeline: Hidalgo to Victoria Counties, Texas. UTSA-ASR 51. (Brooks, Hidalgo, Jim Wells, Kleberg, Nueces, Refugio, San Patricio, and Victoria Counties)

1980 Digging Into South Texas Prehistory. Corona Publishing Company. San Antonio. (Statewide and Regional Syntheses)

1984 The Prehistory of Dimmit County. In Dimmit County Mesquite Roots, L. Tidwell, editor, pp. 1-6. Wind River Press, Austin. (Dimmit County)

Hester, Thomas R. and Jack D. Eaton

1983 Middle-Lower Rio Grande Archaeology. In Borderlands Sourcebook: A Guide to the Literature on Northern Mexico and the American Southwest, E. R. Stoddard, R. L. Nostrand, and J. P. West, editors, pp. 70-74. University of Oklahoma Press, Norman. (Brewster, Cameron, Hidalgo, Kinney, Maverick, Presidio, Starr, Val Verde, Webb, and Zapata Counties)

Hoffrichter, Norma

1981 Texas Archeological Society Field School Excavations at the McKinney Homestead. Appendix $F$ in Archeological Investigations at the Thomas F. McKinney Homestead, Travis County, Texas: An Experiment in Historical Archeology Part I, by Michael McEachern and Ronald W. Ralph. BTAS 51:164-167. (Travis Gounty) 
Hole, Frank

1972 Archeological Investigations of the North End of the San Jacinto

Battleground. Part II in San Jacinto Battleground: Archeological Studies, 1971-1972. Report prepared by the Department of Anthropology, Rice University. On file at THC. (Harris County)

1974 The Acadia: A Civil War Blockade Runner. Rice University, Technical Report 1. (Brazoria County)

Holliday, Vance and James E. Ivey

1974 Presidio-Ojinaga International Flood Control and Channel

Relocation Project, Presidio County, Texas: An Evaluative Survey of the Archeological and Historical Resources. TAS-RR 48. (Presidio County)

Holtzapple, T. and Wayne R. Roberson

1976 Sabine Pass Battleground State Historical Park, Jefferson County, Texas: Archeological Investigations. TPWD-AR 8. (Jefferson County)

Howard, Margaret Ann and Martha Doty Freeman

1983 Inventory and Assessment of Cultural Resources at Bear Creek, Addicks Reservoir, Harris County, Texas. PA-RI 24. (Harris County)

1984 Settlement in the Upper Bull Creek Basin: An Inventory and Assessment of the Cultural Resources at the Canyon Creek Development, Travis County, Texas. PA-RI 32. (Travis County)

Hsu, D. P.

1969 The Arthur Patterson Site, A Mid-Nineteenth Century Site, San Jacinto County, Texas. THG-ASR 5. (San Jacinto County)

Hudgins, Joe D.

1982 An Historic Indian Site in Wharton County, Texas. HAS-N 74:2-7. (Wharton County)

1984a Ceramic Types Found in the East Wharton County and West Fort Bend County Area of Texas. HAS-J 78:9-10. (Fort Bend and Wharton Counties)

1984b Post West Bernard, 1837-1839. HAS-J 81:2-8. (Wharton County)

1985a Post West Bernard, 1837-1839 - Part II. HAS-J 81:21-26. (Wharton County)

1985b Post West Bernard, 1837-1839 - Part III. HAS-J 82:25-31. (Wharton County)

Hudson, William R., Jr., Warren M. Lynn, and Dan Scurlock

1974 Walker Ranch: An Archeological Reconnaissance in Northern Bexar County, Texas. THC-R 26. (Bexar County) 
Humphreys, Gerald and William Singleton

1978 Historic Archeology in Texas. In Texas Archeology: Essays Honoring R. King Harris, Kurt D. House, editor, pp. 69-92. SMU, Institute for the Study of Earth and Man, Report of Investigations 3 . (Statewide Synthesis)

Humphreys, S. B.

1971 The Skeleton Biology of Eighteenth-Century Coahuiltecan Indians from San Juan Capistrano Mission, San Antonio, Texas. M.A. thesis, SMU. (Bexar County)

Ing, J. David

1970 Archeological Investigations, Lyndon B. Johnson State Park, 1970. TPWD 1. (Gillespie County)

1974 San Jacinto Battleground State Park: Archeological Tests at Four Proposed Dump Sites. TPWD-AR 22. (Harris County)

1976 Fort Lipantitlan State Historic Site, Nueces County, Texas, Archeological Testing - 1974. TPWD-AR 16. (Nueces County)

Ing, J. David and George Kegley

1971 Archeological Investigations at Fort Leaton Historic Site, Presidio County, Texas, Spring, 1971. TPWD. (Presidio County)

Ing, J. David and Wayne R. Roberson

1974 Leaton State Historic Site: Summary of Archeological Excavations, and Excavation of Chape1, 1973. TPWD-AR 15. (Presidio County)

Ippolito, John E.

1977 Archeological Investigations at Fort Richardson State Park.

TAMU-ALR 39. (Jack County)

Ippolito, John E. and Edward P. Baxter

1976. An Archeological Survey of the Freeport Harbor 45-Foot Navigation Project, Brazoria County, Texas. TAMU-ALR 21. (Brazoria County)

Ivey, James $\mathrm{E}$.

1976 The Camino Real Crossing of the Trinity River. La Tierra 3(3):15-22. (Madison County)

1978a Archaeological Investigations at the Gresser House (41 BX 369), San Antonio, Texas. UTSA-ASR 60. (Bexar County)

1978b Archaeological Investigations at the Mayer House (41 BX 326), San Antonio, Texas. UTSA-ASR 59. (Bexar County)

1979 The Comanche Spring Site. La Tierra 6(3):16-21. (Bexar County)

1981 A Reexamination of the Site of Presidio of San Sabá. La Tierra 8(4):3-11. (Menard County) 
Ivey, James E. (continued)

1983 Archaeological Testing at Rancho de las Cabras, Wilson County, Texas. Second Season. UTSA-ASR 121. (Wilson County)

n.d. Archaeological Investigations at Mission Concepción and Mission Parkway, Part I: Excavations at Mission Concepción. UTSA-ASR 114. (Contact UTSA for information) (Bexar County)

Ivey, James E., Cristi Assad, Erwin Roemer, Jr., and Jack D. Eaton

1977 An Archaeological and Historical Survey of Walnut Creek, Sequin, Texas. UTSA-ASR 30. (Guadalupe County)

Ivey, James E. and Anne A. Fox

1981 Archaeological Survey and Testing at Rancho de las Cabras, Wilson County, Texas. UTSA-ASR 104. (Wilson County)

Ivey, James E. and Thomas W. Medlin

1977 The Fort McIntosh Problem. La Tierra 4(3):1-6. (Webb County)

Ivey, James E., Thomas W. Medlin, and Jack D. Eaton

1977 An Initial Archaeological Assessment of Areas Proposed for Modification at Fort McIntosh, Webb County, Texas. UTSA-ASR 32. (Webb County)

Jackson, A. T.

1938 Picture-Writing of Texas Indians. The University of Texas Publication 3809. (Statewide Synthesis)

1971 Mills of Yesterday. Texas Western Press, E1 Paso. (Statewide Synthesis)

Jackson, Jack M.

1982 Archeological Investigations of Slave Plantations. In Texana II: Cultural Heritage of the Plantation South (Proceedings of a Public Humanities Conference for the Exploration of Antebellum Texas and Slavery), Candace Volz, editor, PP. 51-57. THC. (Freestone, Hill, and Rusk Counties)

Jackson, Marsha F.

1975 The George Jowell Ranch Complex: A Report on the Preliminary Testing and Evaluation of the Archeological and Architectural Features. THC-AR 27. (Palo Pinto County)

1977 Texana: Excavations at a 19th Century Inland Coastal Town, Jackson County, Texas. TAS-RR 56. Palmetto Bend Reservoir Series I. (Jackson County)

Jackson, Marsha F. and Duford W. Skelton

1975 Fayette Power Project: An Interim Report on the Assessment of its Impact on the Cultural Resources. TAS-TB 8. (Fayette County) 
Jelks, Edward B.

1967 The Gilbert Site: A Norteño Focus Site in Northeastern Texas, Edward B. Jelks, editor. BTAS 37. (Rains County)

1969 Archeological Excavations at Fort Leaton State Park. Manuscript on file at TPWD.' (Presidio County)

1970 Documentary Evidence of Indian Occupation at the Stansbury Site (41-39B1-1). Appendix B in Archeological Investigations in the Whitney Reservoir Area, Central Texas, by R. L. Stephenson. BTAS 41:277-286. (Hi11 County)

Jensen, Hal P.

1968 Archeological Excavations at James S. Hogg Birthplace, Rusk, Texas. SBC-APR 14. (Cherokee County)

Johnson, Charles A. II

1977 A Preliminary Appraisal of Cultural and Historical Resources Found Along the Rio Grande between Fort Quitman and Haciendita, Texas. UTEP-PA 5. (Hudspeth, Jeff Davis, and Presidio Counties)

Johnson, Eilleen, Vance T. Holliday, M. J. Kaczor, and R. Stuckenrath

1977 The Garza Occupation at the Lubbock Lake Site. BTAS 48:83-109. (Lubbock County)

Johnson, LeRoy, Jr. and Edward B. Jelks

1968 The Tawakoni-Yscani Village, 1760: A Study of Archeological Site Identification. TJS 10(4):405-422. (Rains County)

Johnson, Malcom

1979 Black-on-White Pottery from Central Texas. La Tierra 6(4):26-29. (Gillespie County)

Jones, B. Galvin

1968 The Kinsloe Focus: A Study of Seven Historic Caddoan Sites in Northeast Texas. M.A. thesis, The University of Oklahoma. (Gregg, Harrison, and Rusk Counties)

Jones, Courtenay J.

1983 Archaeological Investigations of the Southeast Building Complex, old Ursuline Academy Campus, San Antonio, Texas. UTSA-ASR 118. (Bexar County)

Jones, Courtenay J. and Anne A. Fox

1983 Archaeological Testing at Rancho de las Cabras, Wilson County, Texas, Third Season. UTSA-ASR 123. (Wilson County)

Jurney, David H.

1986 A Newly Discovered East Texas Log Courthouse. BTAS 55:53-60. (Navarro County) 
Katz, Paul R.

19771975 Archaeological Investigations at old Ursuline Academy, San Antonio, Texas. UTSA-ASR.34. (Bexar County)

1978 Archaeological and Historical Investigations in the Arciniega Street Area, Downtown San Antonio, Texas. UTSA-ASR 61. (Bexar County)

Katz, Susanna R. and Anne A. Fox

1979 Archaeological and Historical Assessment of Brackenridge Park, City of San Antonio, Texas. UTSA-ASR 33. (Bexar County)

Keller, John E. and L. Janice Campbell

1984 Patterns in Prehistoric Settlement: Examining the Distribution of Sites in a Portion of the Colorado River Valley, the Colorado Coastal Plains Project, Fayette and Colorado Counties, Texas. New World Research, Report of Investigations 83-11.

(Colorado and Fayette Counties)

Kelley, J. C.

1952 The Historic Indian Pueblos of La Junta de los Rios: Part I. New Mexico Historical Review 27(4):257-295. (Brewster County)

1953 The Historic Indian Pueblos of La Junta de los Rios: Part II. New Mexico Historical Review 28(1):21-51. (Brewster Gounty)

Kelly, Thomas C.

1979 An Archaeological Reconnaissance of the Palafox Mining Area, Webb County, Southern Texas. UTSA-ASR 71. (Webb County)

Kelly, Thomas C. and Erwin Roemer, Jr.

1981 Archaeological and Historical Investigations in Bastrop and Lee Counties, Texas. UTSA-ASR 101. (Bastrop and Lee Counties)

Kindall, Sheldon M.

1984 Excavation of a Site on Galveston Island, 1983. HAS-J 78:7-8. (Galveston Gounty)

1985 The Menard-Morris House: A Preliminary Report. HAS-J 82:2-6. (Harris County)

Kirkland, Forrest

1942 Historic Material from Fielder Canyon Cave. BTAPS 14:61-71. (Val Verde County)

Kotter, Steven M.

1981a Archeological Survey and Assessment of a Pipeline Right-of-Way through Portions of the Cuero I Archeological District, Gonzales and Lavaca Counties, Texas. PA-RI 14. (Gonzales and Lavaca Counties)

1981b-Archeological Survey-and-Assessment in the-Silverlake-Permit-Area, Jim Hogg County, Texas. PA-RI 16. (Jim Hogg County) 
Kotter, Steven M. (continued)

1982 A Preliminary Assessment of the Cultural Resources within the Milican Project, Navasota River Basin, Brazos, Grimes, Leon, Madison and Robertson Counties. PA-RI 19. (Brazos, Grimes, Leon, Madison, and Robertson Counties)

Kotter, Steven M. and Jan A. Guy

1980 Archeological Survey and Assessment of Two Areas to be Affected by Proposed Critical Area Treatment Measures within the Ecleto Creek Watershed, Karnes County, Texas. PA-RI 5. (Karnes County)

Kotter, Steven M. and Linda A. Nance

1980 Archeological Assessments of 41GL57 and 41GL91, Enchanted Rock State Natural Area, Gillespie County, Texas. PA-RI 10. (Gillespie County)

Krone, Milton F.

1978 The Soto Ranch Site. The Artifact 16(4):23-53. (E1 Paso County)

Leutenegger, Benedict

1977 Inventory of the Mission San Antonio de Valero, 1772. THG-SR 23. (Bexar County)

Lorrain, Dessamae

1968 An Archaeologist's Guide to Nineteenth Century American Glass.

Historical Archaeology 2:34-44. (No counties mentioned)

1970 An Archeologist's Guide to Nineteenth Century American Glass. The Record 26(3):19-24. (No counties mentioned)

1971 Archeological Investigations at the Original Site of the MacGregor House, Austin County, Texas. TAS-RR 2. (Austin County)

1972 Archeological Investigations at Fort Richardson State Historic Site, Jack County, Texas. TAS-RR 10. (Jack County)

1973 Fort Richardson Commissary and Quartermaster's Storehouse: Archeological Tests; August 1972. TPWD. (Jack County)

Lorrain, Dessamae and Marsha Jackson

1970 Archeological Investigations at Washington-on-the-Brazos. Manuscript on file at TPWD. (Washington County)

Lorrain, Paul

1979 The Cellar at the Gano Log Cabin Site. The Record 35(1):6-7. (Tarrant County)

Lowery, Mable

1969 Fort Leaton State Historical Park, Presidio County, Texas. TPWD. (Presidio County)

Luke, Clive J.

1978 The Marshall Powder Mill Site. SDHPT 11. (Harrison County) 
Lynn, Warren M.

1978 Archeological Investigations at the Sam Rayburn House Museum, Bonham, Texas. Privately printed. On file at TARL. (Fannin County)

n.d. Draft Technical Report of Archeological Survey and Excavation on Quintana Island, Texas. Manuscript on file at THC. (Brazoria County)

Lynn, Warren M., Daniel E. Fox, and Nancy. O'Malley

1977 Cultural Resource Survey of Choke Canyon Reservoir, Live Oak and McMullen Counties, Texas. THC-ASR 20. (Live Oak and McMullen Counties)

McClenny, Jon, Melissa Voellinger, and J. David Ing

1978 Fulton Mansion State Historic Structure, Fulton, Texas, 41AS79, Archeological Testing and Monitoring. TPWD. (Aransas County)

McEachern, Michael and Ronald W. Ralph

1980a Archeological Investigations at the Thomas F. McKinney Homestead, Travis County, Texas: An Experiment in Historical Archeology Part I. BTAS 51:5-127. (Travis County)

1980b Texas Parks and Wildlife Department Excavations at the Mckinney Homestead (41TV289): Description of House Artifacts and Recommendations for Architectural Reconstruction. Appendix D in Archeological Investigations at the Thomas F. McKinney Homestead, Travis County, Texas: An Experiment in Historical Archeology Part I. BTAS 51:146-161. (Travis County)

McGuff, Paul R.

1978 Prehistoric Archeological Investigations at Palmetto Bend Reservoir: Phase I, Jackson County, Texas. TAS-RR 58. Palmetto Bend Reservoir Series 3. (Jackson County)

McGuff, Paul R. and Wayne N. Cox

1973 A Survey of the Archeological and Historical Resources to be Affected by the Clear Creek Flood Control Project, Texas. TAS-RR 28. (Brazoria, Fort Bend, Galveston, and Harris Counties)

McGuff, Paul R. and William B. Fawcett, Jr.

1978 Phase II: Palmetto Bend Archeological Investigations, Re-evaluative Survey and Testing. TAS-RR 67. Palmetto Bend Reservoir Series 4. (Jackson County)

McGuff, Paul R. and Mary M. Ford

1974 Galveston Bay Area, Texas: A Study of Archeological and Historical Resources Under Investigation for Navigation Improvement. TAS-RR 36. (Galveston County) 
McGuff, Paul R. and Wayne R. Roberson

1974 Lower Sabine and Neches Rivers, Texas and Louisiana: A Study of the Prehistoric and Historic Resources in Areas Under Investigation for Navigation Improvement. TAS-RR 46. (Jefferson and Orange Counties)

McIntosh, Roderick (editor)

1982 Archaeological Excavations at the Kellum-Noble House Site: 1982

Season. Report prepared by the Department of Anthropology, Rice University. (Harris County)

McIntosh, Roderick J. and Roger Moore (editors)

19831983 Season: Archaeological Excavations at the Kellum-Noble House Site. Report prepared by the Department of Anthropology, Rice University. (Harris County)

McReynolds, Mary Jane

1981 Archeological Investigations at the Laredo Cemetery Site (41WB22), Webb County, Texas. PA-RI 11. (Webb County)

McReynolds, R. L.

1982 An Iron Projectile from Gillespie County, Texas. La Tierra 9(2):30-32. (Gillespie County)

Mallouf, Michael G.

1975 Three Rivers Flood Protection: Live Oak County, Texas: An Archeological and Historical Survey of Areas Proposed for Modification. TAS-TB 9. (Live Oak County)

Mallouf, Robert J., Daniel E. Fox, and Alton K. Briggs

1973 An Assessment of the Cultural Resources of Palmetto Bend Reservoir, Jackson County, Texas. Texas Historical Commission and Texas Water Development Board, Archeological Survey Report 11. (Jackson County)

Malone, James $\mathrm{M}$.

1970 Archeological Reconnaissance in the Mackenzie Reservoir Area of Tule Canyon. THC-ASR 8. (Briscoe County)

Malone, James M., Georgeanna H. Greer, and Helen Simons

1979 Kirbee Kiln: A Mid-19th Century Texas Stoneware Pottery. THG-R 31. (Montgomery County)

Marmaduke, William S. and W. Hayden Whitsett

1975a An Archaeological Reconnaissance in the Central Davis Mountains, Texas. In Mount Livermore and Sawtooth Mountain, A Natural Area Survey (Supplement to Part III of IV, Published 1973, Supplemented 1975), Griffin Smith, editor, pp. 24-59. Published by the Division of Natural Resources and Environment, The University of Texas at Austin. (Jeff Davis County) 
Marmaduke, William S. and W. Hayden Whitsett (continued)

1975b An Archaeological Reconnaissance in the Devil's River - Dolan Falls Area. In Devil's River, A Natural Area Survey Part VI of VIII, Griffin Smith, editor, Pp. 76-109. Published by the Division of Natural Resources and Environment, The University of Texas at Austin. (Val Verde County)

1975c An Archaeological Reconnaissance in the Vicinity of the Devil's Sinkhole. In Devil's Sinkhole Area - - Headwaters of the Nueces River, A Natural Area Survey Part VIII. of VIII, Griffin Smith, editor, pp. 88-117. Published by the Division of Natural Resources and Environment, The University of Texas at Austin. (Edwards and Real Counties)

1975d Reconnaissance and Archaeological Studies in the Canadian River Valley. In Canadian Breaks A Natural Area Survey, Part VII of VIII, Griffin Smith, editor, pP. 68-126. Published by the Division of Natural Resources and Environment, The University of Texas at Austin. (01dham County)

Mercado-Allinger, Patricia A.

1983 Survey, Testing and Assessment of Cultural Resources in Portions of Willacy County Drainage District No. 1, Willacy County, Texas. PA-RI 20. (Willacy County)

Mercado-Allinger, Patricia A., Ross Fields, Kathleen Gilmore, and Nancy Reese 1984 Inventory and Assessment of Cultural Resources, Clear Lake Channel Improvement Project, Galveston and Harris Counties, Texas. PA-RI 26. (Galveston and Harris Counties)

Mercado-Allinger, Patricia A., Elton R. Prewitt, and Crystal Sasse Ragsdale 1984 Inventory and Assessment of Cultural Resources in Portions of the Buttercup Creek Subdivision, Williamson County, Texas. PA-RI 30 . (Williamson County)

Mercado-Allinger, Patricia A. and Crystal Sasse Ragsdale

1984 Inventory and Assessment of Cultural Resources, Jamail Property Development, Williamson County, Texas. PA-RI 28. (Williamson County)

Middleton, John

1982 The Wallisville Heritage Park Foundation. HAS-N 73:11-14. (Chambers County)

Miroir, M. P., R. King Harris, Jay C. Blaine, and J. McVay

1973 Bernard de la Harpe and the Nassonite Post. BTAS 44:113-167. (Bowie County)

Mitche11, Jimmy L.

1974 Notes on Metal Projectile Points from Southern Texas. Journal of South Texas 1:47-51. (Bexar, Dimmit, Frio, and Zavala Counties) 
Mitchell, Jimny L. (continued)

1980 Brief Notes on the Archaeology of Mission San Juan de Capistrano. La Tierra 7(4):18-26. (Bexar County)

Mitche11, Jimmy L. and Lynn Highley

1982 Notes on a Metal Projectile Point from Southern Texas: The Brom Cooper Collection. La Tierra 9(1):21-23. (Victoria County)

Mobley, Charles M.

1976 Archaeological Investigations at Fort Concho, Texas. SMU-RR 98. (Tom Green County)

Moncure, Henry B.

1984 Historical Archeology at the Walling Cabin 41RK104, Rusk County, Texas. TAS-RR 88. (Rusk County)

Moncure, Henry B. and Jack M. Jackson

1982 A Cultural Resource Survey of the Proposed Martin Lake Area D Railroad and Transmission Line, Rusk County, Texas. TAS-TB 57. (Rusk County)

Moore, Bill

1985 A Cultural Resources Survey of the Proposed Pecan Creek Park, Hamilton County, Texas. Report prepared for the Gity of Hamilton, Texas, by the Archeological Research Laboratory, Texas A\&M University. On file at THC. (Hamilton Gounty)

Moore, Gary L., Frank A. Weir, John E. Keller, R. Whitby

Jarvis, Catherine H. Yates, K. Joan Jelks, and Philip A. Bandy

1972 Temporary Capitol of Texas, 1883-1888: History and Archaeology. SDHPT 1. (Travis County)

Moore, Roger

1978 Navigation on the Trinity River. In A Reconnaissance Survey of the Trinity River Basin 1976-1977, Jeffrey J. Richner and Joe T. Bagot, assemblers, pp. 96-118. SMU-RR 113. (Anderson, Chambers, Collin, Dallas, Denton, Ellis, Fannin, Freestone, Grayson, Henderson, Hill, Hood, Houston, Johnson, Kaufman, Leon, Liberty, Limestone, Madison, Navarro, Parker, Polk, San Jacinto, Tarrant, Trinity, Van Zandt, Walker, and Wise Counties)

1984a An Archaeological Analysis of Geotechnical Soil Core Data Collected for the Metro Stage One, RRS Project, Houston, Texas. Report prepared for Houston Transit Consultants, Houston, Texas. On file at THC and Metropolitan Transit Authority, Houston, Texas. (Harris County).

1984b Preliminary Results from 200 Main Street Testing. HAS-J 78:2-4. (Harris County)

1984c Archaeological Impact Assessment: Galveston Trolley Project, Phase I. Report prepared for Ochsner and Associates, Inc. On file at THC. (Galveston County) 
Moore, Roger and Texas Anderson

1984 Gilded Age Archaeology: Excavations at Ashton Villa. Archaeology $37(3): 44-50$. (Galveston County)

Moore, Roger and Lorraine Heartfield

1982 Significance Testing at Site 41-LB-41, A Historic Site in Liberty County, Texas. Report prepared by Heartfield, Price and Greene, Inc., for Brown and Root, Inc., Houston, Texas. (Liberty County)

Morrow, Herbert $C$.

1975 Marfa Border Patrol Headquarters - Fort D. A. Russel. Report prepared by Herbert Morrow, Consultant. On file at THC. (Brewster County)

1978 The Study of an Adobe Building in Ysleta, Texas: The AldereteCandelaria House. The Artifact 16(3):108. (E1 Paso County)

Mounger, Maria Allen

1959 Mission Espiritu Santo of Coastal Texas: An Example of Historic Site Archeology. M.A. thesis, The University of Texas at Austin. (Goliad County)

Nelson, George

1981 Preliminary Archaeological Survey and Testing at Fort Inge, Texas. Uvalde County Historical Commission, Uvalde. (Uvalde County)

Newcomb, W. W., Jr.

1955 An Historic Burial from Yellowhouse Canyon, Lubbock County. BTAS 26:186-199. (Lubbock County)

Newcomb, W. W., Jr. and Forrest Kirkland

1967 The Rock Art of Texas Indians. University of Texas Press. (Brewster, Concho, El Paso, Presidio, San Saba, and Terrell Counties)

Nichols, Peter W.

1981a A Cultural Resource Inventory and Assessment of the Proposed Stacy Reservoir, Concho, Coleman, and Runnels Counties, Texas, Vol. II Historical Cultural Resources. EHA, Document 81052. (Coleman, Concho, and Runnels Counties)

1981b Proposed Deepwater Channel and Multipurpose Terminal Construction and Operation near Brownsville, Texas. EHA, Document 80487. (Cameron County)

Nichols, Peter W., Richard A. Hubbard, and Leonard R. Voellinger

1979 Cultural Resources Survey: Phase II Plant Site/Cooling Pond Survey; Mine Area Predictive Model, South Hallsville Project. EHA, Document 78102. (Harrison County) 
Nunley, Parker

1973 An Assessment of Archeological Resources in the Vicinity of Garza-Little Elm Reservoir. Richland Archeological Society Miscellaneous Papers 1. (Denton County)

O'Malley, Nancy

1976 An Archeological Reconnaissance of a Portion of the Rio Grande, Starr County, Texas. In Rio Grande-Falcon Thorn Woodland, A Natural Area Survey 13, Griffin Smith, editor, pp. 77-92. Published by the Lyndon B. Johnson School of Public Affairs, The University of Texas at Austin. (Starr County)

O'Malley, Nancy, Lynn Osborne Bobbitt, and Dan Scurlock

1976 A Historical and Archeological Investigation of Roma, Texas. THC-SR 20. (Starr County)

Olds, Dorris L.

1967 The French Legation Kitchen. Prepared by TARL for the Daughters of the Republic of Texas. (Travis County)

1969 Archeological Investigations at Fort Griffin Military Post, Shackelford County, Texas. TARL (Shackelford County)

1976 Texas Legacy from the Gulf: A Report of Sixteenth Century Shipwreck Materials Recovered from the Texas Tidelands. Texas Memorial Museum, Miscellaneous Publication 5; TAG-P 2. (Willacy County)

Olsen, S. C. and Curtis Tunne11

1975 Mission Concepción. Archeological Completion Report Series 5. Division of Grants, Office of Archeology and Historic Preservation, National Park Service, Department of the Interior. (Bexar County)

Ozee, Delevan W.

1955 An Historic Indian Cache in Clay County. BTAS 26:256-258. (Clay County)

Parker, Wayne

1979 Mackenzie's Supply Gamp. Grain Producer's News 30(7):40-47. (Crosby County)

1982 An Ox Shoe and Metal Scraping Tool from the Montgomery Site.

La Tierra 9(2):27-29. (Floyd County)

1983 Three Metal Projectile Points from a Historic Indian Workshop. La Tierra 10(1):39-42. (Crosby County)

Parsons, Mark L.

1967 Archeological Investigations in Crosby and Dickens Counties, Texas during the Winter, 1966-1967. SBC-APR 7. (Crosby and Dickens Counties) 
Parson, Mark L. (continued)

1972 Archeological Investigations at Hedwig's Hill, Mason County, Texas. Report prepared for the Ranch Headquarters Association, the Museum of Texas Tech University. On file at THC. (Mason County)

Parsons, Mark L., James E. Corbin, and Curtis D. Tunnel1

1965 A Preliminary Report on Archeological Investigations at Washington-on-the-Brazos, 1964. Unpublished manuscript on file at TARL. (Washington County)

Patterson, L. W. , Ron Murk, and Suzanne Murk

1984 Site 41 HR 525, Another Long Occupation Sequence in Harris County, Texas. HAS-J 78:11-14. (Harris County)

Patterson, Patience E.

1980 Relocation and Restoration of a Baking Oven (Site 41VV588) in Val Verde County, Texas. SDHPT 18. (Val Verde County)

Patterson, Patience E. and Mary M. Ford

1974 Oso Creek Flood Control Project Area, Nueces County, Texas: A Report on the Archeological and Historical Resources. TAS-RR 35. (Nueces County)

Perino, Gregory

1968 Benton Metal Points. In Guide to the Identification of Certain American Indian Projectile Points, Gregory Perino, editor, pp. 10-11. Oklahoma Anthropological Society, Special Bulletin 3. (McLennan, Montague, and Rains Counties)

Pettengi11, Shirley J.

1977 Report for 1975 and 1976 of Archeological Investigations at Fort Concho. Manuscript on file at THC. (Tom Green County)

Pevey, Jody C.

1981 The Sam Houston Home, 41WA46, Huntsville, Walker County, Texas: 1979-1981 Archeological Investigations and Monitoring. PA-RI 12. (Walker County)

Pevey, Jody C. and Judy Van Cleve

1981 An Archeological Survey and Assessment of Overhead Power Distribution Lines, Fayette, Lavaca and Austin Counties, Texas. PA-RI 13. (Austin, Fayette, and Lavaca Counties)

Phillips, Charles A.

1982 Adolphus Sterne House Site: Analytical Report of the Physical Remains. Report on file at the Department of Anthropology, SFA. (Nacogdoches County)

Pliska, James R., Bruce A. Nightengale, and Jack M. Jackson

1980 A Cultural Resource Inventory and Assessment of the North Tract, Big Brown Lignite Project, Freestone County, Texas. TAS-RR 78. (Freestone County) 
Pollan, Johnney T., Jr.

1984 Location of the Earliest Wharton Family Cemetery at the Eagle Island Plantation. La Tierra 11(4):2-12. (Brazoria County)

Pope, Charles S. and Don Rickey, Jr.

1966 Fort Leaton, Presidio County, Texas. Report prepared for the United States Department of the Interior, National Park Service by TPWD. (Presidio County)

Prewitt, Elton R.

1973 An Archeological Reconnaissance of the Areas to be Affected by the Proposed Louisiana Loop Pipeline, Cameron Parish, Louisiana, Jefferson and Liberty Counties, Texas. TAS-RR 25. (Jefferson and Liberty Counties)

1984 Archeological and Historical Investigations in the Proposed Baker's Port Project and Vicinity, Southern Live Oak Peninsula, San Patricio County, Texas. PA-RI 25. (San Patricio County)

Prewitt, Elton R., John W. Clark, Jr., and David S. Dibble

1972 An Assessment of the Archeological and Historical Resources of the Bayou Loco Reservoir Area, Nacogdoches County, Texas. TAS-RR 11. (Nacogdoches County)

Prewitt, Elton R. and Kerry A. Grombacher

1974 An Archeological and Historical Assessment of the Areas to be Affected by the Proposed Twin Oak and Oak Knoll Projects, East-Central Texas. TAS-RR 43. (Limestone and Robertson Counties)

Prewitt, E1ton R. and Linda A. Nance

1980 Archeological Survey and Assessments on the McBryde Lease, Duval County, Texas. PA-RI 7. (Duval County)

Prikryl, Daniel J. and Crystal Sasse Ragsdale

1984 Inventory and Assessment of Cultural Resources, Scofield Farms Development, Travis County, Texas. PA-RI 31. (Travis County)

Raab, L. Mark

1982 Settlement of the Prairie Margin: Archaeology of the Richland Creek Reservoir, Navarro and Freestone Counties, Texas 1980-1981. A Research Synopsis. SMU-AM 1. (Freestone and Navarro Counties)

Ralph, Ron

1982 Report from the Survey Crew. Texas Archeology 26(3):8. (Williamson County)

Raun, Gerald G.

1964 West Indian Seal Remains from Two Historic Sites in Coastal South Texas. BTAS 35:189-192. (Nueces County)

Ray, Cyrus N. and Edward B. Jelks

1964 The W. H. Watson Site: A Historic Indian Burial in Fisher County, Texas. BTAS 35:127-142. (Fisher County) 
Redder, Albert $\mathrm{J}$.

1967 Trade Tomahawk. CTAS-N 1(4):10-11. (McLennan County)

1972 Site 41KX20. Site Survey. Unpublished manuscript on file at TARL. (Knox County)

Reed, Erik K.

1938 Burials at Mission Espíritu Santo. CTAS 4:83-95. (Goliad County)

Richner, Jeffrey $\mathrm{J}$. and Joe T. Bagot (assemblers)

1978 A Reconnaissance Survey of the Trinity River Basin 1976-1977. SMU-RR 113. (Anderson, Chambers, Collin, Dallas, Denton, Ellis, Fannin, Freestone, Grayson, Henderson, Hill, Hood, Houston, Johnson, Kaufman, Leon, Liberty, Limestone, Madison, Navarro, Parker, Polk, San Jacinto, Tarrant, Trinity, Van Zandt, Walker, and Wise Counties)

Richner, Jeffrey $J$. and T. Reed Lee

1976 Cultural Resources at Tennessee Colony Lake SMU-RR 87. (Anderson, Freestone, Henderson, and Navarro Counties)

1977 Archaeological and Ethnohistorical Survey at Tennessee Colony Lake 1975. SMU-RR 104. (Anderson, Freestone, Henderson, and Navarro Counties)

Riggs, Aaron D., Jr.

1965 Petroglyphs of Garza County, Texas. In Bulletin I, Southeastern New Mexico and West Texas Symposium Papers, pp. 9-14. Published by the Lea County, New Mexico Archeological Society. (Garza County)

198241 SC 3: A Historic Pictograph Site in Scurry County, Texas. In Transactions of the 17th Regional Symposium for Southeastern New Mexico and Western Texas, Jim Cozzourt, editor, pp. 165-166. Published by the Panhandle Archeological Society. (Scurry County)

Roberson, Wayne $R$.

1972 The Study of Extinct Rural Communities in the United States: A Test of Feasibility. M.A. thesis, The University of Texas at Austin. (Hays County)

1974 The Carrington-Covert House: An Archeological Investigation of a 19th Century Residence in Austin, Texas. THG-R 25. (Travis County)

Roberson, Wayne $R$. and $J$. David Ing

1974 Fort Richardson State Historic Park: Archeological Tests at the Bakery Building, September 1973. TPWD-AR 16. (Jack County)

Roberson, 'Wayne R. and Thomas W. Medlin

1976 San José Mission State Historic Site, Archeological Testing 1974 and 1976. TPWD. (Bexar County) 
Roemer, Erwin, Jr., Shawn Bonath Carlson, and Cristi Assad

1983 Archeological Testing at Varner-Hogg State Park, May and June, 1983. Report prepared by Archeological Research Laboratory, Texas A\&M University for $0 i 1$ and Gas Exploration, Friendswood, Texas. (Brazoria County)

Schuetz, Mardith $\mathrm{K}$.

1966 Historic Background of the Mission San Antonio de Valero. SBC-APR 1. (Bexar County)

1968 The History and Archeology of Mission San Juan Gapistrano, San Antonio, Texas (Volume I, Historical Documentation and Description of the Structures). SBG-APR 10. (Bexar County)

1969a The History and Archeology of Mission San Juan Capistrano, San Antonio, Texas (Volume II, Description of the Artifacts and EthnoHistory of the Goahuiltecan Indians). SBC-APR 11. (Bexar County)

1969b The Quarteles of San Antonio de Bexar. Manuscript on file at THC. (Bexar County)

1970a Archeological Investigations at Mission San Jose in Apri1 1968. THSC-AR 19. (Bexar County)

$1970 \mathrm{~b}$ Excavation of a Section of the Acequia Madre in Bexar County, Texas and Archeological Investigations at Mission San José in April 1968. SBC-APR 19. (Bexar County)

1973 Archeological Investigations at Mission San Antonio de Valero, the Second Patio. Unpublished manuscript on file at THC. (Bexar County)

1974 The Dating of the Chapel at Mission San Juan Capistrano, San Antonio, Texas. THG-SR 12. (Bexar County)

1980a An Historical Outline of Mission San Juan de Capistrano. La Tierra 7(4):3-15. (Bexar County)

1980b The Indians of the San Antonio Missions. Ph.D. dissertation, The University of Texas at Austin. (Bexar County)

1983 Spanish Colonial Building Techniques in San Antonio. In Texana I: The Frontier, LeRoy Johnson, Jr., editor, pp. 17-20. THC. (Bexar County)

Scurlock, Dan

1976 Archeological and Architectural Tests at Mission San Juan Capistrano Church, March and April, 1975. THC-SR 21. (Bexar County)

Scurlock, Dan, Adan Benavides, Jr., Dana Isham, and John W. Clark, Jr. 1976 An Archeological and Historical Study of the Proposed Mission Parkway, San Antonio, Texas. THC-ASR 17. (Bexar County) 
Scurlock, Dan and Daniel E. Fox

1977 An Archeological Investigation of Mission Concepción, San Antonio, Texas. TAS-SR 2. (Bexar County)

Scurlock, Dan and William R. Hudson, Jr.

1973 An Archeological Investigation of Walker Ranch. THC-SR 9.' (Bexar County)

Scurlock, Dan, Warren M. Lynn, and Thomas Ray

1974 An Assessment of the Archeological Resources of Padre Island National Seashore, Texas. THC-SR 11. (Kenedy and Kleberg Counties)

Scurlock, Dan and Theodore B. Powers

1973 Spain in North America: Selected Sources on Spanish Colonial History, Archeology, Architecture and Art, and Material Culture. THG-SR 8. (Statewide Synthesis)

1975 Interim Report for Mission Concepción (Archeological Investigation) San Antonio, Bexar County, Texas. THC-SR 7. (Bexar County)

Scurlock, Dan and William W. Schroeder

1971 Archeological Survey for Shipwreck Sites in Northwestern Matagorda Bay, June 1-12, 1971. THG-SR 6. (Calhoun County)

Shafer, Harry J.

1966 An Archeological Survey of the Wallisville Reservoir, Chambers County, Texas. TAS-SR 2. (Chambers County)

1974 An Archeological Reconnaissance of the Brownsville Relocation Study Area. TAMU-ALR 1. (Cameron County)

Shawn, Ronnie

1975 The Bull Hill Site Excavation. In Transactions of the Tenth Regional Archeological Symposium for Southeastern New Mexico and Western Texas, pp. 1-47. Published by the South Plains Archeological Society. (Midland County)

Simons, Helen

1982 The Gaines-McGown Site: Archeological Investigations and Related Research. Manuscript on file at THC. (Sabine County)

Skeels, Lydia Lowndes Maury

1972 An Ethnohistorical Survey of Texas Indians. THC-R 22. (Statewide Synthesis)

Skelton, Duford W. and Martha Doty Freeman

1980 A Cultural Resource Inventory and Assessment at Camp Swift, Texas. TAS-RR 72. (Bastrop County)

Skinner, S. Alan

1971 Historical Archeology of the Neches Saline, Smith County, Texas. THG-R 21. (Smith County) 
Skinner, S. Alan (continued)

1979 The Archaeology of East Texas Lumbering. East Texas Historical Journal 17:36-44. (Sabine County)

1982 Archaeology and History of Lake Ray Roberts, Volume 2, Construction Area Testing. Report prepared by Environmental Consultants, Inc., Gultural Resources Report 82-9. (Denton County)

Skinner, S. Alan and Debora T. Conners

1979 Archaeological Investigations at Lakeview Lake. SMU-RR 118. (Dallas, Ellis, and Tarrant Counties)

Skinner, S. Alan, R. King Harris, and Keith M. Anderson

1969 Archaeological Investigations at the Sam Kaufman Site, Red River County, Texas. SMU-CA 5. (Red River County)

Smith, Harvey P., Jr.

1980 Espada Mission: Research and Restoration. La Tierra 7(2):3-18. (Bexar County)

1981 Spanish Governor's Palace. La Tierra 8(2):3-15. (Bexar County)

Smith, Ray

1984 Notes on Three Iron Projectile Points from South Texas. La Tierra 11(3):28-30. (Uvalde County)

Smith, Victor $\mathrm{J}$.

1942 Evidence of European Influence in the Pictographs of West Texas. BTAPS 14:38-48. (Brewster, Concho, and Jeff Davis Counties)

1946 Evidence of European Influence in the Pictographs of West Texas II. BTAPS 17:48-62. (Brewster, Concho, E1 Paso, Hudspeth, Jeff Davis, Presidio, Reeves, Stephens, Terrell, and Val Verde Counties)

Smith-Savage, S. and J. David Ing

1982 Fanthrop Inn: A Case Study of Historic Site Development (Part I). Texas Association of Museums Quarterly 7(6):13-14. (Grimes County)

Sorrow, William M.

1972 Archeological Salvage Excavations at the Alamo (Mission San Antonio de Valero) 1970. TASP-RR 4. (Bexar County)

Sorrow, William M. and Wayne N. Cox

1973 Archeological and Historical Resources of the Navasota River Basin, Texas. TAS-RR 26. (Brazos, Grimes, and Madison Counties)

Steen, Charlie R.

1953 Two Early Historic Sites on the Southern Plains. BTAS 24:177-188. (Montague County) 
Stephenson, Robert L.

1947 Archaeological Survey of Whitney Basin: A Preliminary Report. BTAPS 18:129-142. (Bosque and Hill Counties)

1970 Archeological Investigations in the Whitney Reservoir Area, Central Texas. BTAS 41:37-286. (Bosque and Hill Counties)

Stickney, Francis and Teddy Stickney

1975 Midland We11 Site, 41MD-18. In Transactions of the Tenth Archeological Symposium for Southeastern New Mexico and Western Texas, pp. 51-62. Published by the South Plains Archeological Society. (Midland County)

Story, Dee Ann

1982 The Deshazo Site, Nacogdoches County, Texas. Volume I: The Site, Its Setting, Investigation, Cultural Features, Artifacts of Non-Native Manufacture, and Subsistence Remains. Texas Antiquities Committee Permit Series 7. (Nacogdoches County)

1985 The Walton Site: An Historical Burial in McLennan County, Texas. CTAS 10:66-96. (McLennan County)

Suhm, Dee Ann

1962 The White Site: An Historic Indian Burial in Yoakum County, Texas. BTAS 32:85-120. (Yoakum County)

Taylor, A. J.

1986 Archaeological Survey of the CPS-Butler Lignite Prospect, Bastrop and Lee Counties, Texas. UTSA-ASR 151. (Bastrop and Lee Counties)

Taylor, A. J. and Anne A. Fox

1985 Archaeological Testing at Rancho de las Cabras, Wilson County, Texas, Fifth Season. UTSA-ASR 143. (Wilson County)

Taylor, A. J., Anne A. Fox, and I. Waynne Cox

1986 Archaeological Investigations at Morgan Chapel Cemetery (41 BP 200), a Historic Cemetery in Bastrop County, Texas. UTSA-ASR 146. (Bastrop County)

Taylor, H. C., Jr.

1960 Archeological Notes on the Route of Cabeza de Vaca. BTAS 31:273-290. (No counties mentioned)

Texas Archeological Survey - Research Staff

1974 The Historic and Prehistoric Archeological Resources of the Seadock Area. TAS-TB 5. (Brazoria County)

Texas Parks and Wildlife Department

1974a Preservation Plan and Program for Fort Leaton State Historic Site, Presidio County, Texas. TPWD. (Presidio County) 
Texas Parks and Wildlife Department (continued)

1974b Preservation Plan and Program for Rice Family Log Home, Houston County, Texas. TPWD. (Houston County)

1975a Phase III Development Plan and Program for Fort McKavett State Historic Site, Menard County, Texas. TPWD. (Menard County)

1975b Preservation Plan and Program for Fort McKavett State Historic Site, Menard County, Texas. TPWD. (Menard County)

1975c Preservation Plan and Program for Fort Richardson State Historic Park, Jack County, Texas. TPWD. (Jack County)

1976a Preservation Plan and Program for Fort Lancaster State Historic Site, Crockett County, Texas. TPWD. (Crockett County)

1976b Preservation Plan and Program for Landmark Inn State Historic Site, Medina County, Texas. TPWD. (Medina County)

1976c Preservation Plan and Program for Sam Bell Maxey State Historic Structure, Paris, Lamar County, Texas. TPWD. (Lamar County)

1977a Phase IV Development Plan and Program for Fort McKavett State Historic Site, Menard County, Texas. TPWD. (Menard County)

1977b Preservation Plan and Program for José Antonio Navarro State Historic Site, San Antonio, Texas. TPWD. (Bexar County)

1977c Preservation Plan and Program for Magoffin Home State Historic Site, El Paso, Texas. TPWD. (E1 Paso County)

1977d Preservation Plan and Program for Washington-on-the-Brazos State Historical Park, Washington County, Texas. TPWD. (Washington County)

1978 Preservation Plan and Program for Fulton Mansion State Historic Structure, Fulton, Texas. TPWD. (Aransas County)

1980 Preservation Plan and Program for Monument Hill and Kreische Brewery State Historic Sites, Fayette County, Texas. TPWD. (Fayette County)

1982 Phase V Development Plan and Program for Fort McKavett State Historic Site, Menard County, Texas. TPWD. (Menard County)

1983a Preservation Plan and Program for Fanthorp Inn State Historic Site, Anderson, Texas. TPWD. (Grimes County)

1983b Preservation Plan and Program for Sebastopol State Historic Structure, Seguin, Texas (two volumes). TPWD. (Guadalupe County) 
Texas Parks and Wildlife Department (continued)

1983c Preservation Plan and Program for Varner-Hogg Plantation State Historical Park, Brazoria County, Texas (two volumes). TPWD. (Brazoria County)

1984 Preservation Plan and Program for Port Isabel Lighthouse State Historic Structure, Port Isabe1, Texas. TPWD. (Cameron County)

Thompson, Marc

1980 A Survey of Metal Points from Apacheria. The Artifact 18(1):1-10. (E1 Paso County)

Thurmond, J. Peter, Martha Doty Freeman, and Susan L. Andrews

1981 A Preliminary Assessment of the Cultural Resources in the Brazos Natural Salt Pollution Control Project, Kent, King and Stonewali Counties, Texas. PA-RI 18. (Kent, King, and Stonewall Counties)

Tunne11, Curtis D.

1966 A Description of Enameled Earthenware from an Archeological Excavation at Mission San Antonio de Valero (The Alamo). SBG-APR 2. (Bexar County)

1981 Wax, Men and Money: A Historical and Archeological Study of Candelilla Wax Camps along the Rio Grande Border of Texas. THC 32. (Brewster, Hudspeth, and Presidio Counties)

Tunne11, Curtis D. and J. R. Ambler

1967 Archeological Excavations at Presidio San Agustín de Ahumada with a Historical Background by J. V. Clay. SBC-APR 6. (Chambers County)

Tunnel1, Curtis D. and Hal P. Jensen

1969 Archeological Excavations in Lyndon B. Johnson State Park:

Summer, 1968. SBG-APR 17. (Gillespie Gounty)

1971 Proposal for Acquisition and Archeological Study of Brazos Island. THC-SR 4. (Cameron County)

Tunne11, Curtis D. and W. W. Newcomb, Jr.

1969 A Lipan Apache Mission, San Lorenzo de la Santa Cruz 1762-1771. Texas Memorial Museum, Bulletin 14. (Real County)

Turpin, Solveig A.

1982 Seminole Canyon: The Art and Archeology, Val Verde County, Texas. TAS-RR 83. (Val Verde County)

Valdez, Fred, Jr. and Jack D. Eaton

1979 Preliminary Archaeological Investigations of Part of the San Pedro Acequia, San Antonio, Texas. UTSA-ASR 85. (Bexar County)

Victor, Sally S.

1982 Report from the Historical/Archival Crew. Texas Archeology 26(3):7. (Williamson County) 
Voellinger, Leonard R.

1980 Test Excavations of Rock Features Near Hallsville, Harrison County, Texas. EHA, Document 80579. (Harrison County)

1982a An Investigation of the Historical and Archaeological Resources of the Tomball-Pinehurst Transmission Line, Harris and Montgomery Counties, Texas. EHA, Document 82177. (Harris and Montgomery Counties)

1982b A Search for the de Zavala Homesite and other Cultural Resources, Harris County, Texas. EHA, Document 82180. (Harris County)

Voellinger, Leonard R., Cynthia Brandimarte, and Melissa W. Voellinger

1983 Phase I Archaeological Testing in the Jewett Mine Project Area, Leon, Limestone, and Freestone Counties, Texas. EHA, Document 83038. (Freestone, Leon, and Limestone Counties).

Voellinger, Leonard R. and Martha Doty Freeman

1980 A Cultural Resources Survey of the First Impact Areas of the Jewett Mine Project Area. Appendix $C$ in An Assessment of the Cultural Resources of the Jewett Mine Project Area. EHA, Document 80353. (Freestone, Leon, and Limestone Counties)

1982 A Cultural Resources Survey of the First Five-Year Permit Area, Jewett Mine Project. Appendix $D$ in an Assessment of the Cultural Resources of the Jewett Mine Project Area. EHA, Document 81233. (Freestone and Limestone Counties)

Voellinger, Leonard R., Martha Doty Freeman, Thomas H. Hale, Jr., and Melissa W. Voellinger

1980 An Assessment of the Cultural Resources of the Jewett Mine Project Area. EHA, Document 80011. (Freestone, Leon, and Limestone Counties)

Voellinger, Leonard.R., Stephen R. James, and Cynthia Brandimarte 1983 An Investigation of the Cultural Resources of the Wells Branch Development, Travis County, Texas. EHA, Document 83064. (Travis County)

Walters, Evelyn and Rose Mary Rogers

1975 Notes on Presence of Indians of Historic Period in Pecos County and Iraan, Texas Area. In Transactions of the Tenth Regional Archeological Symposium for Southeastern New Mexico and Western Texas, pp. 89-100. Published by the South Plains Archeological Society. (Crockett, Pecos, and Terrell Counties)

Watt, Frank H.

1937 Descriptive Analysis of Glass Indian Trade Beads Found in Central Texas. CTAS 3:61-67. (Hi11 County)

Watt, Frank $H$. and W. P. Meroney

1937-Glass Indian Trade Beads in Central Texas. CTAS 3:52-60. (Hamilton and Hill Counties) 
Wedel, Mildred Mott

1978 La Harpe's 1719 Post on Red River and Nearby Caddo Settlements. Texas Memorial Museum, Bulletin 30. (Bowie County)

Weir, Frank A.

1973 The Marshall Powder Mill: A Preliminary Report. SDHPT 3. (Harrison County)

Westbury, William A.

1976 Archeological Investigations at Fort Richardson State Park 1976. TAMU-ALR 31. (Jack County)

1977 Archeological Investigations at Fort Richardson State Park, Fall 1976. TAMU-ARL 39. (Jack County)

Wetzel, Shirley

1980a Late 19th Century Bottle Making Techniques - Analysis of Glassware from Nottingham, Texas. HAS-N 66:17-21. (Galveston County)

1980b Nottingham, Galveston Island: History of a Late 19th Century Lace Factory. HAS-N 68:4. (Galveston County)

Whitsett, W. Hayden

n.d. 41HR312. Site Survey Forms and Reconnaissance Report for a Late 19th Century and Early 20th Century Brickyard on Cedar Bayou, 1980. Notes on file at TARL. (Harris County)

Widmer, Randolph J. and Anne Sullivan

1984 Recent Archaeological Investigations at the "Maison Rouge" Site, Galveston County, Texas. HAS-J 79:14-19. (Galveston County)

Willey, P. S., Billy R. Harrison, and Jack T. Hughes

1978 The San Pit Site. In Archeology of the MacKenzie Reservoir, by Jack T. Hughes and P. S. Willey. THG-ASR 24:233-253. (Briscoe County)

Williams, Stephen

1961 Historic Sites in the Caddoan Area. In Proceedings of the Fifth Conference on Caddoan Archeology, edited by E. Mott Davis. BTAS 31:78-143. (Statewide Synthesis)

Witte, Adolph $\mathrm{H}$.

1938 Spanish Fort, An Historic Wichita Site. BTAPS 10:234-244. (Montague County)

Woodall, J. Ned

1967 Miscellaneous European Trade Goods. In A Pilot Study of Wichita Indian Archeology and Ethnohistory, Robert E. Bell, Edward B. Jelks, and W. W. Newcomb, Jr., assemblers, PP. 180-183. National Science Foundation Report, Grant GS-964, Washington, D.C. On file at TARL. (Bowie, Lamar, Montague, and Rains Counties) 
Word, James H. and Anne A. Fox

1975 The Cogdell Burial in Floyd County, Texas. BTAS 46:1-63. (Floyd County)

Yates, Catherine $\mathrm{H}$.

1973 Archeological Investigations at Fort Griffin State Historic Park, 1971, Shackelford County, Texas. TAS-RR 24. (Shackelford County)

1975 Archeological Investigations at Fort Griffin. Archeological Completion Report Series 3. Division of Grants, Office of Archeology and Historic Preservation, National Park Service, Department of the Interior. (Shackelford County) 
SUBJECT

ARCHITECTURAL STYLES

Eaton 1980

Fawcett 1980

Freeman 1980

Heck 1978

Hester 1975

Raab 1982

Richner and Bagot 1978

BOARDING HOUSES

Anderson 1980

Glander and Brandimarte 1983

Glander and Victor 1984

Haske11 and McIntosh 1984

McIntosh and Moore 1983

Wetze1 1980a, 1980b

BUILDING TECHNOLOGY

Eaton 1980

Fawcett 1980

Freeman 1980

Heck 1978

Hester 1975

Raab 1982

Richner and Bagot 1978

Schuetz 1983

CABINS ( $\log$ )

Cliff, Carter, and Verrett 1974

Coleman, Carlson, and Carlson 1984

Fox, D., Mallouf, O'Malley, and Sorrow 1974

Glander and Brandimarte 1983

Granberry 1977

Hal1, Grombacher, and Dibble 1974

Ing 1970

Jurney 1986

Lorrain, P. 1979

Moncure 1984

Moncure and Jackson 1982

Nichols, Hubbard, and Voellinger 1979

Prewitt, Clark, and Dibble 1972

Texas Parks and Wildlife Department 1974b

Voellinger, Freeman, Hale, and Voellinger 1980

Voellinger, James, and Brandimarte 1983 
CAMPS

Buffalo Hunter Camps

Thurmond, Freeman, and Andrews 1981

Line Camps

Freeman and Freeman 1981

Scurlock, Lynn, and Ray 1974

Railroad Labor Camps

Briggs 1974

Kotter 1982

Patterson 1980

\section{CATHEDRALS}

San Fernando

Fox, D., Scurlock, and Clark 1977

CEMETERIES AND GRAVES (see also Historic Indian Burials)

Bandy 1981

Bond 1980

Bond, Glander, and Brandimarte 1984

Carlson, Assad, Roemer, and Carlson 1983

Cliff, Carter, and Verrett 1974

Coleman, Carlson, and Carlson 1984

Comstock, Grombacher, and Dibble 1973

Day, Day, and Prewitt 1981

Dibble and Freeman 1979

Everett 1981

Ferring and Reese 1982

Fields, Freeman, and Kotter 1983

Fox, A. 1984, n.d.b

Fox, A. and Livingston 1979

Freeman 1978

Freeman and Freeman 1981

Freeman and Hale 1978

Fritz 1975

Glander and Brandimarte 1983

Glander and Victor 1984

Guderjan 1981

Hester 1978

Howard and Freeman 1983

Ippolito and Baxter 1976

Kelly 1979

Kelly and Roemer 1981

Kotter 1982

Kotter and Guy 1980 


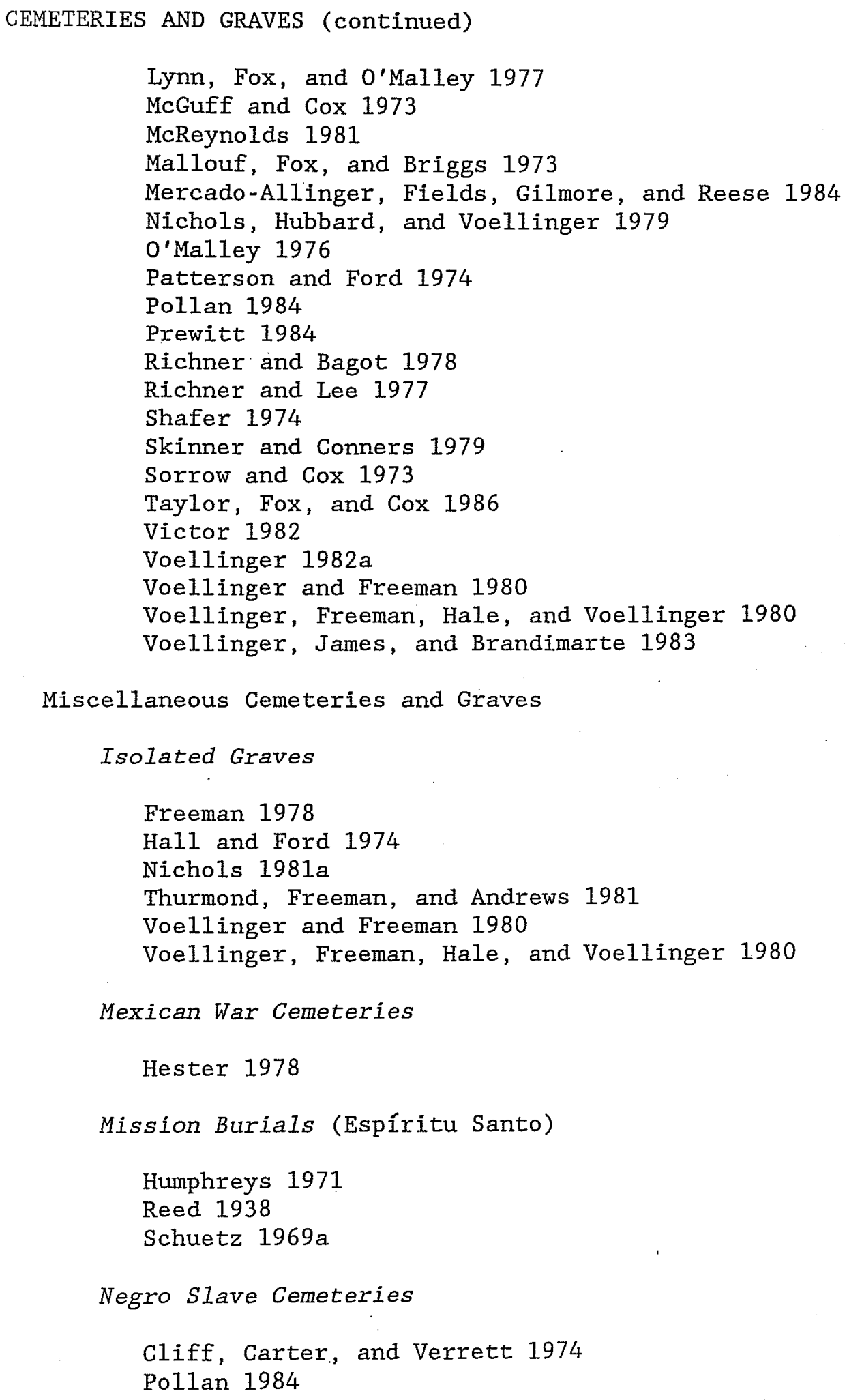


CHURCHES (see also Missions)

Fox, D., Mallouf, O'Malley, and Sorrow 1974

Fox, D., Scurlock, and Clark 1977

Freeman and Hale 1978

Howard and Freeman 1983

Keller and Campbell 1984

O'Malley, Bobbitt, and Scurlock 1976

Pevey and Van Cleve 1981

COMMERCIAL SITES

Briggs 1981

Freeman 1978

Guderjan 1981

Hal1, Grombacher, and Dibble 1974

Haske11 1984

Haskell and McIntosh 1984

Kotter 1982

Mercado-Allinger, Fields, Gilmore, and Reese 1984

Mercado-Allinger, Prewitt, and Ragsdale 1984

Mercado-Allinger and Ragsdale 1984

Moore 1984b

O'Malley, Bobbitt, and Scurlock 1976

Pevey and Van Cleve 1981

Voellinger and Freeman 1982

DOMESTIC SITES (see also Gabins, Dugouts, Farmsteads, Plantations, Ranches, and Residences, urban)

Eighteenth Century

Skinner and Conners 1979

Nineteenth Century

Bandy 1981

Black 1980, 1981

Black, Burnett, and Ing 1978

Boice 1980

Bond 1980

Bond, Glander, and Brandimarte 1984

Brandimarte 1982

Briggs 1981

Brown 1977

Brown, Potter, Hall, and Black 1982

Brown, Widmer, Govaars, and Rubenstein 1985

Carlson, Assad, Roemer, and Carlson 1983

Clark 1974b

Comstock, Grombacher, and Dibble 1973

Duke and Muller 1980

Everett 1981

Fawcett and McGuff 1969 
DOMESTIC SITES (continued)

Nineteenth Century (continued)

Fields 1984

Fields and Jackson 1984

Fields and Reese 1984

Fox, A. 1979a, 1984, 1986

Fox, D. 1982

Fox, D. and Lynn 1976

Fox, D., Mallouf, O'Malley, and Sorrow 1974

Freeman 1978

Freeman and Freeman 1981

Freeman and Hale 1978

Fritz 1975

Glander and Brandimarte 1983

Glander and Victor 1984

Greer, J. 1979

Guderjan 1981

Haskel1 and McIntosh 1984

Hoffrichter 1981

Holliday and Ivey 1974

Howard and Freeman 1983, 1884

Ing 1970

Ivey 1979

Ivey, Assad, Roemer, and Eaton 1977

Jensen 1968

Kindal1 1985

Kotter 1982

Kotter and Guy 1980

Lorrain, D. 1971

McClenny, Voellinger, and Ing 1978

McEachern and Ralph 1980a, 1980b

McGuff 1978

McGuff and Cox 1973

McGuff and Fawcett 1978

McGuff and Ford 1974

Mallouf, Fox, and Briggs 1973

Mercado-Allinger, Fields, Gilmore, and Reese 1984

Mercado-Allinger and Ragsdale 1984

Nichols, Hubbard, and Voellinger 1979

o'Malley 1976

Prewitt 1984

Prewitt, Clark, and Dibble 1972

Prewitt and Grombacher 1974

Richner and Lee 1976, 1977

Skinner 1982

Skinner and Conners 1979

Sorrow and Cox 1973

Voellinger 1980

Voellinger $1982 \mathrm{~b}$

Voellinger and Freeman 1980, 1982

Widmer and Sullivan 1984 
DOMESTIC SITES (continued)

Twentieth Century

Bandy 1981

Bond, Glander, and Brandimarte 1984

Brown, Widmer, Govaars, and Rubenstein 1985

Carlson, Assad, Roemer, and Carlson 1983

Day, Day, and Prewitt 1981

Ensor, Carlson, and Carlson 1983

Everett 1981

Fields and Jackson 1984

Fox, D., Mallouf, O'Malley, and Sorrow 1974

Freeman 1978

Freeman and Freeman 1981

Freeman and Hale 1978

Glander and Brandimarte 1983

Glander and Victor 1984

Guderjan 1981

Haske11 and McIntosh 1984

Howard and Freeman 1983, 1984

Ivey 1978a, 1978b

Kotter 1982

Kotter and Nance 1980

Lynn 1978

McGuff and Roberson 1974

Mercado-Allinger, Fields, Gilmore, and Reese 1984

Mercado-Allinger, Prewitt, and Ragsdale 1984

Mercado-Allinger and Ragsdale 1984

Nichols, Hubbard, and Voellinger 1979

O'Malley 1976

Prewitt 1984

Prewitt, Clark, and Dibble 1972

Skinner 1982

Thurmond, Freeman, and Andrews 1981

Voellinger 1982b

Voellinger and Freeman 1980, 1982

Miscellaneous (date not known)

Baskin 1976b

Ferring and Reese 1982

Marmaduke and Whitsett $1975 \mathrm{c}$

Nunley 1973

DUGOUTS

Bousman 1974

Fox, A. 1986

Freeman and Freeman 1981

Malone 1970

Thurmond, Freeman, and Andrews 1981 
ETHNOHISTORY (see also Historic Indians)

Aten 1983

Bel1, Jelks, and Newcomb 1967

Campbel1 and Campbe11 1981

Davis, E. M. 1970

Raab 1982

Schuetz 1980a, 1980b

Skeels 1972

Story 1985

FARMSTEADS

Nineteenth Century

Carlson 1983, 1984

Carter, E. and Ragsdale 1976

Chaffin-Lohse 1978

Dibble and Freeman 1979

Duke 1977a, 1977b

Ferring 1983

Ferring and Reese 1982

Few 1982

Fields, Freeman, and Kotter 1983

Fox, A. 1979c, 1986

Fox, A. and Livingston 1979

Fox, D., Mallouf, O'Malley, and Sorrow 1974

Freeman 1978, 1983

Gerstle, Kelly, and Assad 1978

Gregg 1980a, 19.80b, 1981a, 1981b

Jackson, M. and Skelton 1975

Johnson 1977

Keller and Campbell 1984

Mercado-Allinger and Ragsdale 1984

Moore and Heartfield 1982

Nichols, Hubbard, and Voellinger 1979

Nunley 1973

Parsons 1972

Prikryl and Ragsdale 1984

Tunne11 and Jensen 1969

Voellinger and Freeman 1980, 1982

Voellinger, James, and Brandimarte 1983

Twentieth Gentury

Ferring 1983

Ferring and Reese 1982

Fields, Freeman, and Kotter 1983

Fox, D. , Mallouf, O'Malley, and Sorrow 1974

Freeman 1978, 1983

Glander and Victor 1984

Johnson 1977

Keller and Campbel1 1984 
FARMSTEADS (continued)

Twentieth Century (continued)

Kelly and Roemer 1981

Kotter 1982

Mercado-Allinger and Ragsdale 1984

Mercado-Allinger, Prewitt, and Ragsdale 1984

Nichols, Hubbard, and Voellinger 1979

Parsons 1972

Prikryl and Ragsdale 1984

Voellinger and Freeman 1980, 1982

Voellinger, James, and Brandimarte 1983

Miscellaneous (date not known)

Coleman, Carlson, and Carlson 1984

Fawcett 1983

Lynn, Fox, and O'Malley 1977

Taylor 1986

FEATURES

Baking Ovens

Patterson 1980

Cattle Pens

Fox, A. and Cox 1983

Cellars

Brown, Widmer, Govaars, and Rubenstein 1985

Fields and Reese 1984

Ing 1970

Lorrain, P. 1979

Prikryl and Ragsdale 1984

Dipping Vats (livestock)

Pevey and Van Cleve 1981

Fill (urban)

Moore $1984 \mathrm{c}$

Irrigation Pumps

McGuff and Fawcett 1978 
FEATURES (continued)

Rock Piles and Cairns

Bond, Glander, and Brandimarte 1984

Freeman 1978

Freeman and Freeman 1981

Mercado-Allinger and Ragsdale 1984

Nichols, Hubbard, and Voellinger 1979

Voellinger 1980

Sheep Dip Tanks

Fox, A. and Cox 1983

Silos (grain)

Kotter 1981b

Stone with Eighteenth-Century Inscription

Hart 1972

Water Tanks

Collett 1984

HISTORIC INDIANS

Burials

Bennett 1968

Davis, E. M. 1970

Doran and Malina 1974

Fox, A. n.d.b

Hester 1968

Newcomb 1955

Parsons 1967

Ray and Jelks 1964

Reed 1938

Story 1982, 1985

Suhm 1962

Word and Fox 1975

Lithics (Mission Indians)

Fox, D. 1979b

Hester 1977, 1980

Metal Arrow Points

Harris and Harris $1969 \mathrm{~b}$

Hester 1968, 1970, 1980, 1984 
HISTORIC INDIANS (continued)

Metal Arrow Points (continued)

McReynolds, R. 1982

Mitchell 1974

Mitchell and Highley 1982

Perino 1968

Shawn 1975

Smith, R. 1984

Walters and Rogers 1975

Pueblos

Kelley 1952, 1953

Rock Art Sites

Baskin 1976a

Jackson, A. 1938

Marmaduke and Whitsett $1975 \mathrm{~b}$

Newcomb and Kirkland 1967

Riggs 1965, 1982

Smith, V. 1942, 1946

Turpin 1982

Sites (miscellaneous)

Aten 1983

Bastian 1967

Bell, Jelks, and Newcomb 1967

Blaine 1967

Blaine and Harris 1966

Briggs 1971

Campbe11 1956

Gampbell and Campbell 1981

Cliff, Carter, and Verrett 1974

Conger 1953

Davis, E. M. 1970

Davis, Gilmore, Harper, Harris, Jelks, and Yancy 1966

Davison and Harris 1974

Denton 1983

Dickinson 1941

Doran and Malina 1974

Duffield and Jelks 1961

Duke 1974c

Eagleton 1955

Fritz 1975

Fullen 1978

Gilmore 1974a

Guffee 1976b

Haaskarl 1957

Harper, Harper, Harris, Harris, Jelks, and Woodall 1966 
HISTORIC INDIANS (continued)

Sites (miscellaneous; continued)

Harris, I. 1966, 1967

Harris, R. K. 1940, 1946, 1953a, 1953b, 1960, 1962

Harris and Blaine 1966

Harris and Harris 1961, 1962, 1967, 1969a, 1969b, $1969 c, 1969 d, 1975 b, 1978,1980$

Harris, Harris, and Blaine 1974

Harris, Harris, Blaine, and Blaine 1965

Harris, Harris, and Miroir 1980

Harris, Harris, and Woodal1 1966

Harris and Shiner 1973

Harris and Tunnel1 1966

Hester 1977, 1978, 1979, 1984

Holliday and Ivey 1974

Hsu 1969

Hudgins $1982,1984 a$

Jelks 1967, 1970

Johns on 1979

Johnson, Holliday, Kaczor, and Stuckenrath 1977

Johnson and Jelks 1968

Jones, B. 1968

Kirkland 1942

McReynolds, R. 1982

Marmaduke and Whitsett 1975a, 1975b, 1975c, 1975d

Mitchell and Highley 1982

Ozee 1955

Parker 1982, 1983

Parsons 1967

Patterson and Ford 1974

Prewitt, Clark, and Dibble 1972

Redder 1967, 1972

Shawn 1975

Skinner, Harris, and Anderson 1969

Steen 1953

Stephenson 1947, 1970

Story 1982,1985

Suhm 1962

Thompson 1980

Turpin 1982

Walters and Rogers 1975

Watt 1937

Watt and Meroney 1937

Wede1 1978

Willey, Harrison, and Hughes 1978

Williams 1961

Witte 1938

Woodal1 1967 
INDUSTRIAL SITES

Blacksmith Shops

Keller and Campbe11 1984

Breweries

Kreische Brewery

Texas Parks and Wildlife Department 1980

Brick-Making Sites

Cartier and Hole $1972 \mathrm{a}$

Keller and Campbel1 1984

Mallouf, Fox, and Briggs 1973

Brickyards

Whitsett n.d.

Cane Syrup Processing Localities

Clark 1976

Kotter 1982

Story 1982

Cement Plants

Katz and Fox 1979

Copper Mines

Thurmond, Freeman, and Andrews 1981

Cotton Gins

Freeman and Freeman 1981

Fritz 1975

Pevey and Van Cleve 1981

Voellinger and Freeman 1980

Cotton Presses

Fritz 1975

Moore $1984 \mathrm{c}$

Grist Mills

Durrenberger 1965

Fox, A. 1979c

Katz and Fox 1979 


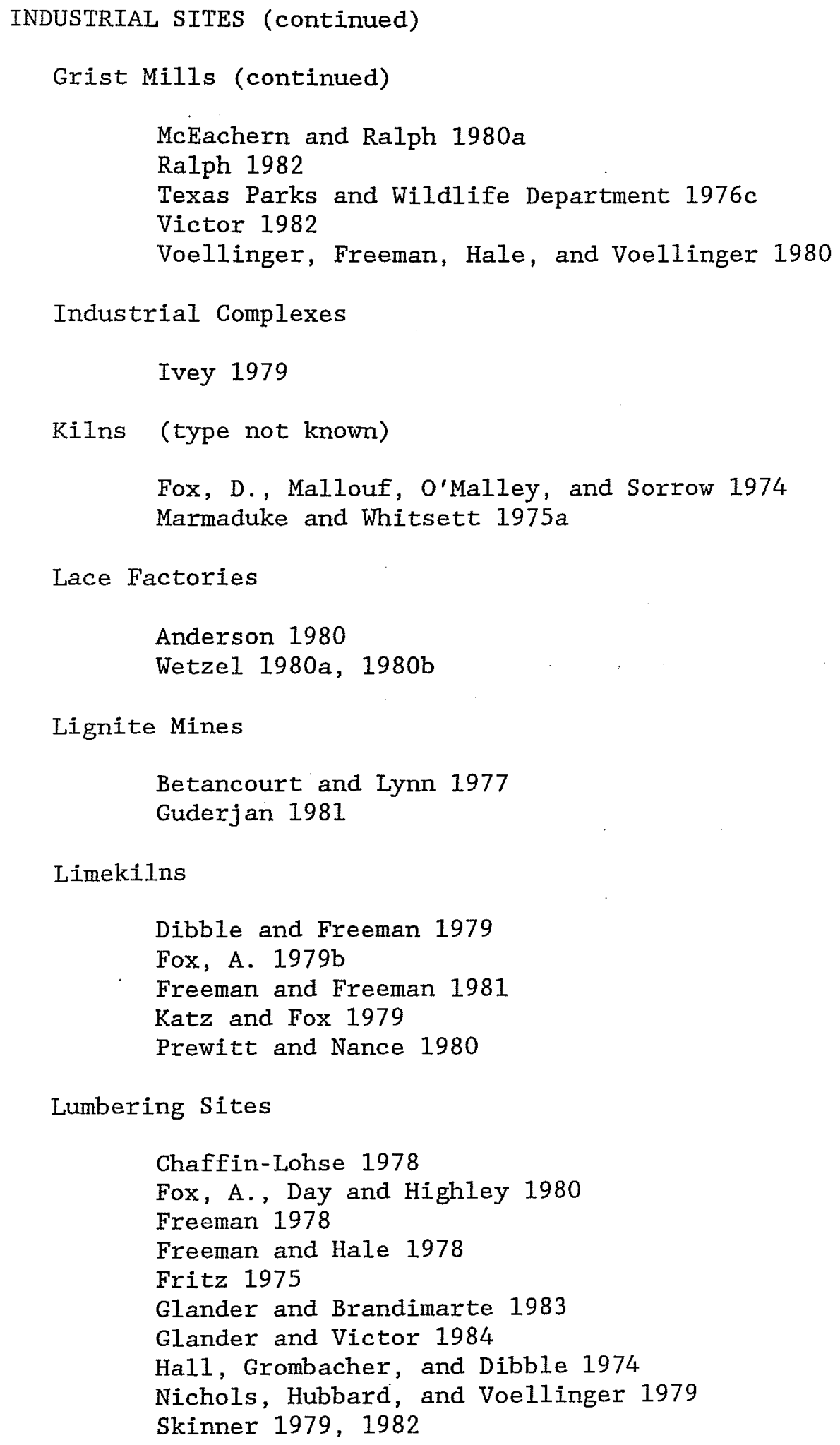


INDUSTRIAL SITES (continued)

Mills (general)

Durrenberger 1965

Fox, A. 1979c

Fox, A., Day, and Highley 1980

Jackson, A. 1971

Katz and Fox 1979

Luke 1978

McEachern and Ralph 1980a

Moore 1985

Ralph 1982

Texas Parks and Wildlife Department 1976 c

Victor 1982

Weir 1973

Mines (genera1)

Betancourt and Lynn 1977

Carlson, Assad, Roemer, and Carlson 1983

Guderjan 1981

Thurmond, Freeman, and Andrews 1981

Voellinger, Brandimarte, and Voellinger 1983

Voellinger and Freeman 1982

Mine Shafts

Carlson, Assad, Roemer, and Carlson 1983

Oil Fields

McGuff and Roberson 1974

Pottery-Making Sites

Brackner 1982

Greer, G. 1983

Jackson, M. 1977

Malone, Greer, and Simons 1979

Nunley 1973

Powder Mills

Luke 1978

Weir 1973

Power Plants

Mercado-Allinger, Fields, Gilmore, and Reese 1984 
INDUSTRIAL SITES (continued)

Quarries (limestone)

Fox, A. 1979c

Katz and Fox 1979

Salt Works

Hall, Grombacher, and Dibble 1974

Skinner 1971

Sawmills

Chaffin-Lohse 1978

Freeman 1978

Freeman and Hale 1978

Fritz 1975

Glander and Brandimarte 1983

Glander and Victor 1984

Hall, Grombacher, and Dibble 1974

Nichols, Hubbard, and Voellinger 1979

Skinner 1982

Sorghum Presses

Freeman 1978

Nichols, Hubbard, and Voellinger 1979

Stills

Fox, D. $1980 \mathrm{~b}$

Sugar Refineries

Clark 1976

Fawcett 1980

Fritz 1975

Texas Archeological Survey - Research Staff 1974

Tanneries

Katz and Fox 1979

Tramways

Glander and Victor 1984

Skinner 1979

Wax Processing Camps

Tunne11 1981 
64 Historical Bibliography

INDUSTRIAL SITES (continued)

Miscellaneous

Freeman 1978

McGuff and Fawcett 1978

Nichols, Hubbard, and Voellinger 1979

INNS/STAGECOACH STOPS

Burnett 1981

Day, Day, and Prewitt 1981

Fox, D. Mallouf, O'Malley, and Sorrow 1974

Freeman and Hale 1978

Prewitt 1984

Smith-Savage and Ing 1982

Texas Parks and Wildlife Department 1976c, 1983a

MILITARY SITES

Barracks

Schuetz 1969b

Battlefields

Jones Creek

Hall, Grombacher, and Dibble 1974

Palo Alto

Baxter and Killen 1976

Bond 1979

Hester 1978

Shafer 1974

Resaca de la Palma

Hester 1978

Sabine Pass

Holtzapple and Roberson 1976

McGuff and Roberson 1974

San Jacinto

Cartier and Hole $1972 \mathrm{~b}$

Duke 1974a, 1974b

Hole 1972

Ing 1974 


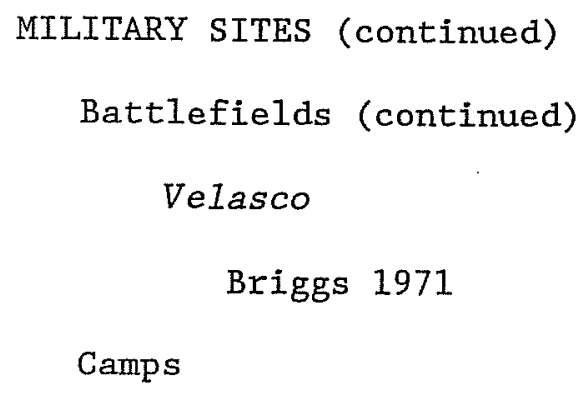

Depots

Mexican War

Boggs n.d.

Hall and Grombacher 1974

Nichols 1981b

Tunne11 and Jensen 1971 


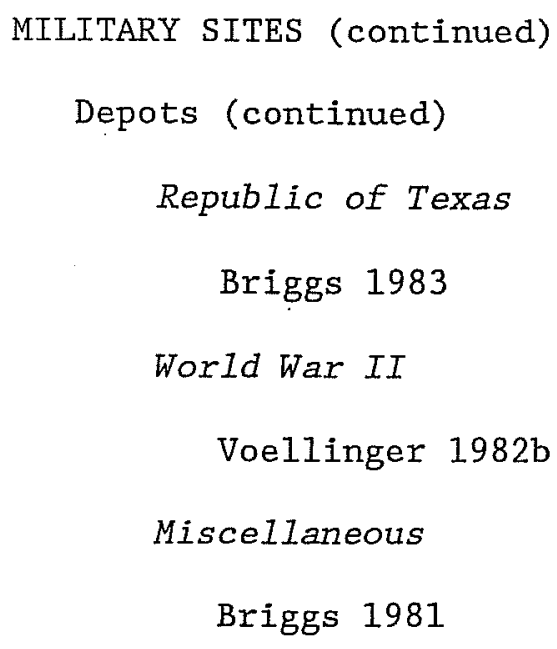

Dugouts

Thurmond, Freeman, and Andrews 1981

Forts

Brown

Briggs 1971

Concho

Bell, Klein, and Hoffman 1980

Coffman and Ground 1970

Mobley 1976

Pettengi11 1977

Graham

Stephenson 1947, 1970

Griffin

Fox, A. 1973, 1976

Olds 1969

Yates 1973, 1975

Ing

Ne1son 1981

Kenny

Fox, D., Whitsett, and Jurgens 1981 
MILITARY SITES (continued)

Forts (continued)

Lancaster

Black 1974

Clark 1972

Hays and Jelks 1966

Texas Parks and Wildlife Department 1976a

\section{Leaton}

Ing and Kegley 1971

Ing and Roberson 1974

Jelks 1969

Lowery 1969

Pope and Rickey 1966

Texas Parks and Wildlife Department $1974 a$

Lipantitlan

Briggs 1971

Ing 1976

\section{McIntosh}

Fox, D. 1979a

Hester 1978

Hester and Eaton 1983

Ivey and Medlin 1977

Ivey, Medlin, and Eaton 1977

McKavett

Black and Ing 1980

Garter, E. 1974

Green 1969

Texas Parks and Wildlife Department 1975a, 1975c, $1977 d, 1982$

Polk

Briggs 1971

Tunnell and Jensen 1971

Richardson

Dickson 1976

Ippolito 1977

Lorrain, D. 1972, 1973

Roberson and Ing 1974 


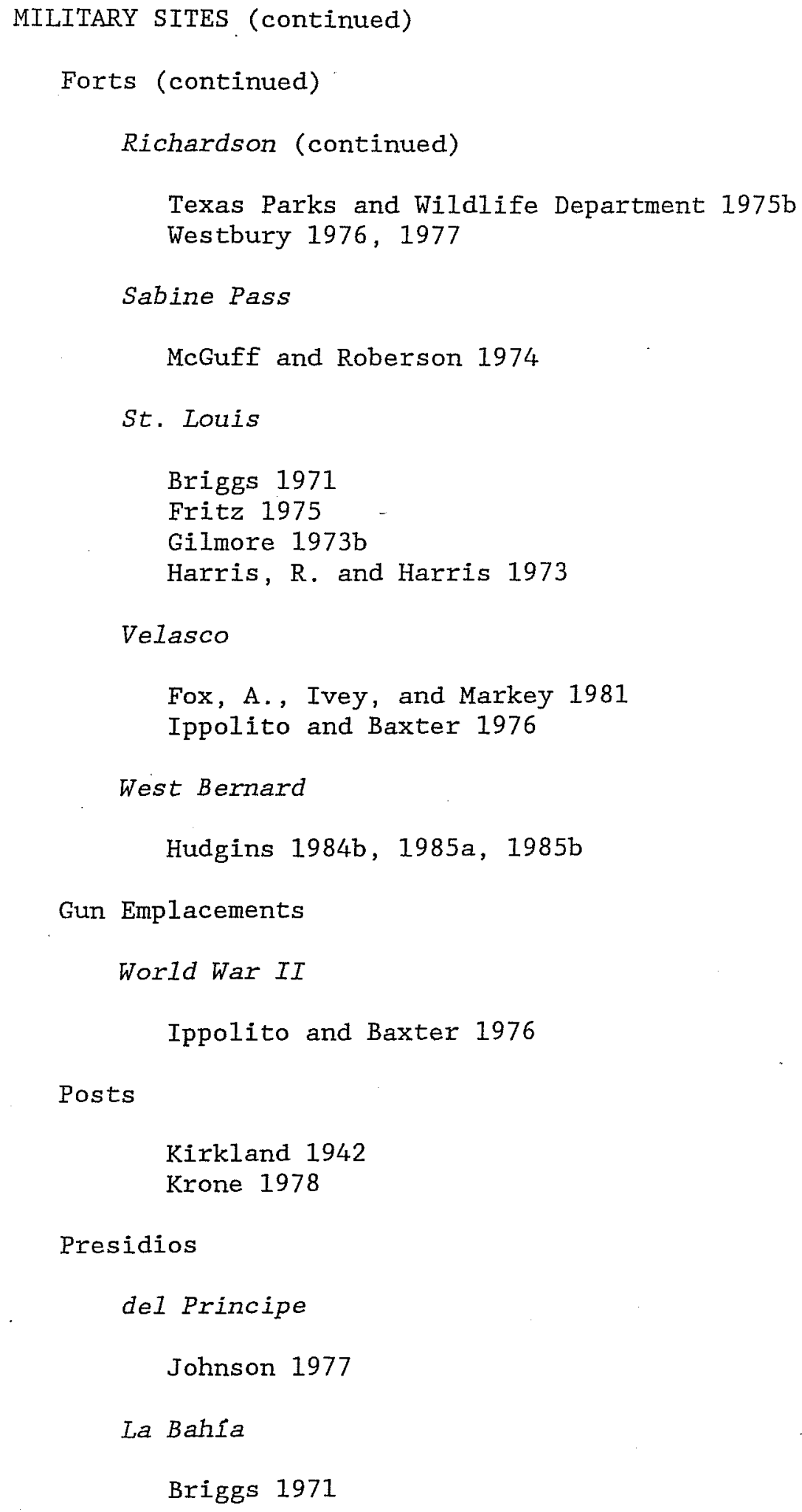




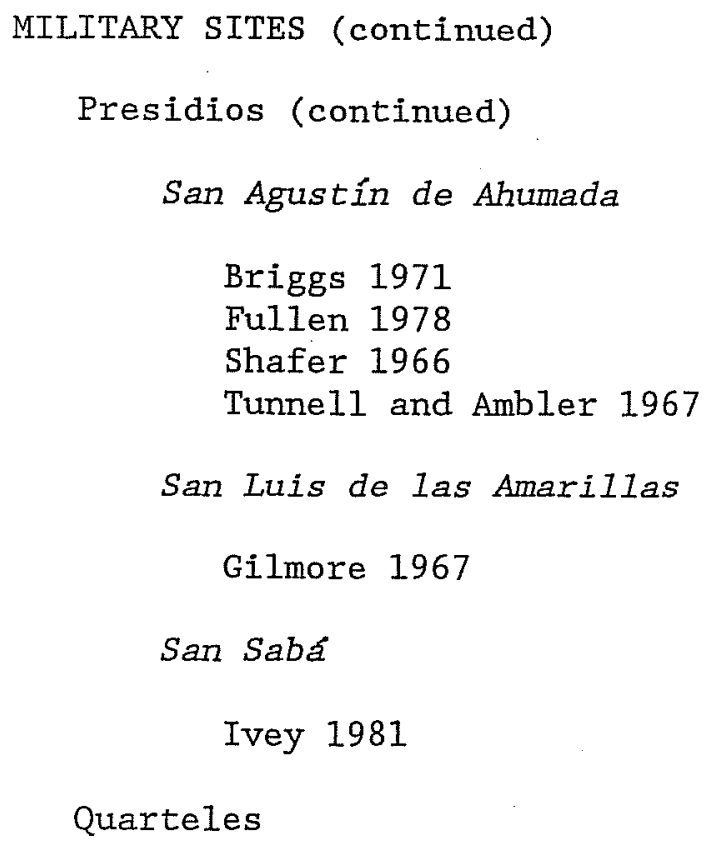


MISSIONS (Spanịsh)

Alamo (San Antonio de Valero)

Campbell and Campbel1 1981, 1985

Eaton 1980, 1981

Fox, A., Bass, and Hester 1976

Greer, J. 1967

Leutenegger 1977

Schuetz 1966, 1973

Sorrow 1972

Tunne11 1966

Dolores de los Ais

Corbin, Kalina, and Alex 1980

Nuestra Señora del Espíritu Santo de Zuñiga (La Bahía)

Briggs 1971

Mounger 1959

Raun 1964

Reed 1938

Nuestra Señora de la Luz

Briggs 1971

Fullen 1978

Nuestra Señora de la Purísima Concepción de Acuña

Campbel1 and Campbel1 1981, 1985

Cook 1980

Fox, A. n.d.a

Harris, I. 1967

Ivey n.d.

Olsen and Tunnell 1975

Scurlock and Powers 1975

Scurlock and Fox 1977

Nuestra Señora del Refugio

Briggs 1971

Nuestra Señora del Rosario

Briggs 1971

Gilmore 1974b, $1974 \mathrm{c}$

Harris, R. and Harris 1974a, 1974b, 1975a

San Bernardo 


\section{MISSIONS (continued)}

San Francisco de la Espada

Campbe11 and Campbe11 1985

Clark 1976, 1978, 1980a

Clark and Prewitt 1979

Fox, A. 1981

Fox, A. and Hester 1976

Smith 1980

San José

Campbel1 and Campbel1 1981, 1985

Fox, D. 1970

Harris, I. 1967

Henderson and Clark 1984

Roberson and Medlin 1976

Schuetz 1970a, 1970b

San Juan Bautista

Hester 1978

Hester and Eaton 1983

San Juan Capistrano

Campbell and Campbell 1985

Humphreys 1971

Mitchel1 1980

Schuetz 1968, 1969a, 1974, 1980a

Scurlock 1976

San Lorenzo de la Santa Cruz

Cook 1981

Tunnell and Newcomb 1969

Santa Gruz de San Sabá

Gilmore 1967

San Xavier

Gilmore 1969, 1982

Miscellaneous

Campbell and Campbel1 1981

Fox, D. 1979b

Gilmore 1978

Hester 1980

Schuetz 1980b

Scurlock, Benavides, Isham, and Clark 1976 
OUTBUILDINGS

Barns

Brooks and Baskin 1976

Coleman, Carlson, and Carlson 1984

Fox, D., Mallouf, O'Malley, and Sorrow 1974

Freeman and Freeman 1981

Keller and Campbell 1984

Prikryl and Ragsdale 1984

Voellinger and Freeman 1980

Voellinger, Freeman, Hale, and Voellinger 1980

Corrals

Keller and Campbe11 1984

Cribs

Freeman 1976

Glander and Brandimarte 1983

Nichols, Hubbard, and Voellinger 1979

Kitchens

Ing 1970

Olds 1967

Latrines

Prikryl and Ragsdale 1984

Log Pens

Voellinger, Freeman, Hale, and Voellinger 1980

Milk Houses

Freeman and Freeman 1981

Root Cellars

Freeman and Freeman 1981

Mercado-Allinger, Prewitt, and Ragsdale 1984

Sheds

Dibble and Jackson 1980

Smokehouses 


\section{OUTBUILDINGS (continued)}

Storm Cellars

Freeman and Freeman 1981

We11 Houses

Ing 1970

Miscellaneous

Bond, Glander, and Brandimarte 1984

Fox, D., Mallouf, O'Malley, and Sorrow 1974

Fox, D., Whitsett, and Jurgens 1981

Freeman 1978

Freeman and Freeman 1981

Glander and Brandimarte 1983

Keller and Campbell 1984

Nichols, Hubbard, and Voellinger 1979

O'Malley, Bobbitt, and Scurlock 1976

Voellinger and Freeman 1980, 1982

Voellinger, Freeman, Hale, and Voellinger 1980

Voellinger, James, and Brandimarte 1983

OVERVIEWS AND SYNTHESES

Red River Basin (historical overview)

'Davis 1970

Regional Synthesis

Central and South Texas

Hester 1975,1980

Upper Texas Coast

Aten 1983

Route of Cabeza de Vaca

Campbel1 and Campbel1 1981

Taylor 1960

Spanish Colonial Texas (bibliography)

Scurlock and Powers 1973 
OVERVIEWS AND SYNTHESES (continued)

Texas Archaeology (historic)

Fox, D. 1980a, 1983

Humphreys and Singleton 1978

PARK STRUCTURES AND FEATURES

Brackenridge Park

Fox, A. 1979c

Jockey Club of San Antonio

Katz and Fox 1979

Lambert Bathing Beach

Katz and Fox 1979

Monument Hi11

Texas Parks and Wildlife Department 1980

Pavilions

Katz and Fox 1979

Witte Memorial Museum

Katz and Fox 1979

Zoos

Fox, A. 1979 c

PLANTATIONS

Corbin and Kisling 1983

Crouch 1982

Fawcett 1983

Freeman 1978, 1980

Fritz 1975

Hall, Grombacher, and Dibble 1974

Jackson, J. 1982

McGuff and Fawcett 1978

Nichols, Hubbard, and Voellinger 1979

Phillips 1982

Pliska, Nightengale, and Jackson 1980

Pollan 1984

Prewitt 1984

Roemer, Garlson, and Assad 1983 
PLANTATIONS (continued)

Skinner and Conners 1979

Texas Archeological Survey - Research Staff 1974

Texas Parks and Wildlife Department 1983c

PRIVIES

Anderson 1981, 1983

Carter, S. 1973

Moore and Anderson 1984

PUBLIC BUILDINGS

Gapitol of Texas

Moore, G., Weir, Keller, Jarvis, Yates, Jelks, and Bandy 1972

City Halls

Mercado-Allinger, Fields, Gilmore, and Reese 1984

Courthouses

Morrow 1978

Sunken Gardens of San Antonio

Katz and Fox 1979

Witte Museum

Fox, A. $1979 c$

RANCHES

Eighteenth Century

Story 1982

Nineteenth Century

Carlson 1983

Day, Day, and Prewitt 1981

Everett 1981

Fox, A. 1979a

Freeman 1976

Freeman and Freeman 1981

Freeman and Hale 1978

Greer, J. 1979

Hal1, Grombacher, and Dibble 1974

Hudson, Lynn, and Scurlock 1974

Jackson, M. 1975 
RANCHES (continued)

Nineteenth Century (continued)

Johnson 1977

Lynn, Fox, and O'Malley 1977

Marmaduke and Whitsett $1975 \mathrm{~d}$

Raun 1964

Scurlock and Huds on 1973

Twentieth Century

Bousman 1974

Fox, A. and Cox 1983

Freeman and Freeman 1981

Heartfield, Price and Greene, Inc. 1980

Howard and Freeman 1984

Johnson 1977

Kelly 1979

Kotter 1982

Lynn, Fox, and O'Malley 1977

Pevey and Van Cleve 1981

Miscellaneous

Briggs 1971

Krone 1978

Nichols $1981 \mathrm{~b}$

Scurlock, Lynn, and Ray 1974

RANCHOS (Mission)

Rancho de las Gabras

Ivey 1983

Ivey and Fox 1981

Jones and Fox 1983

Taylor and Fox 1985

San Francisco de la Espada

Clark 1976, 1978, 1980a

Clark and Prewitt 1979

Fox, A. 1981

Fox, A. and Hester 1976

Smith, H. 1980

Orcoquisac Indian Rancho

Fullen 1978 


\section{RANGER STATIONS}

Ivey, Assad, Roemer, and Eaton 1977

\section{RESIDENCES}

Anderson 1981, 1983

Brown, Widmer, Govaars, and Rubenstein 1985

Clark 1980b

Coffman and Freeman 1985

Fields and Jackson 1984

Fox, D., Valdez, and Bobbitt 1978

Gilmore 1973a

Haskel1 1984

Haskel1 and McIntosh 1984

Ivey 1978a, 1978b

Katz and Fox 1979

Keller and Campbel1 1984

Kindal1 1984

McIntosh 1982

McIntosh and Moore 1983

Moore and Anderson 1984

Morrow 1978

O'Malley, Bobbitt, and Scurlock 1976

Pevey 1981

Roberson 1974

Texas Parks and Wildlife Department 1976b, 1977a, $1977 \mathrm{~b}, 1978,1983 \mathrm{~b}$

Widmer and Sullivan 1984

RESORTS

Hot We11s

Fox and Highley 1985

Freeman and Hale 1978

Piedmont Springs

Sorrow and Cox 1973

SCHOOLS AND ACADEMIES

Ursuline Academy

Clark 1974a

Jones, C. 1983

Katz, P. 1977

Miscellaneous

Fox, D., Mallouf, O'Malley, and Sorrow 1974 Freeman 1978 
SCHOOLS AND ACADEMIES (continued)

Miscellaneous (continued)

Freeman and Freeman 1981

Freeman and Hale 1978

Guderjan 1981

Howard and Freeman 1983

Ivey, Assad, Roemer, and Eaton 1977

Morrow 1978

Nichols, Hubbard, and Voellinger 1979

Skinner 1982

SHIPWRECKS

Civil War

Hole 1974

McGuff and Roberson 1974

Eighteenth Century

Fox, A., Day, and Highley 1980

McGuff and Roberson 1974

Miscellaneous

Garrison 1983

Mallouf, Fox, and Briggs 1973

Scurlock and Schroeder 1971

Nineteenth Century

Arnold 1974, 1976, 1977, 1982

Briggs 1971

Hole 1974

McGuff and Roberson 1974

Moore 1978

Richner and Bagot 1978

Seventeenth Century

Briggs 1971

Sixteenth Century

Arnold 1976, 1977

Arnold and Clausen 1975

Arnold and Weddle 1979

Hays and Herrin 1970

olds 1976 


\section{SHIPWRECKS (continued)}

Steamboat Wrecks

Arnold 1974

Fritz 1975

Hal1, Grombacher, and Dibble 1974

Moore 1978

Prewitt 1973

Richner and Bagot 1978

Twentieth Century

Arnold 1982

Fritz 1975

SPANISH COLONIAL SITES

Campbel1 and Campbell 1981

Cartier and Hole 1972b

Fox, A. 1977, 1979b, 1983

Fox, D., Scurlock, and Clark 1977

Guffee 1976b

Shafer 1974

Smith, H. 1980, 1981

Story 1982

\section{STANDING STRUCTURES}

Nineteenth Century

Anderson 1981, 1983

Coleman, Carlson, and Carlson 1984

Fox, D., Whitsett, and Jurgens 1981

Freeman 1978

Freeman and Freeman 1981

Glander and Brandimarte 1983

Jurney n.d.

Katz and Fox 1979

Krone 1978

Mercado-Allinger, Fields, Gilmore, and Reese 1984

Mercado-Allinger and Ragsdale 1984

Moore 1985

Moore and Anderson 1984

Nichols, Hubbard, and Voellinger 1979

o'Malley 1976

Skinner 1982

Voellinger and Freeman 1980, 1982

Voellinger, Freeman, Hale, and Voellinger 1980

Voellinger, James, and Brandimarte 1983 
STANDING STRUCTURES (continued)

Twentieth Century

Bond 1980

Coleman, Carlson, and Carlson 1984

Freeman 1978

Freeman and Freeman 1981

Glander and Brandimarte 1983

Howard and Freeman 1984

Keller and Campbel1 1984

Mercado-Allinger, Fields, Gilmore, and Reese 1984

Mercado-Allinger, Prewitt, and Ragsdale 1984

Mercado-Allinger and Ragsdale 1984

Moore 1985

Nichols, Hubbard, and Voellinger 1979

o'Malley 1976

Prewitt and Grombacher 1974

Skinner 1982

Voellinger 1982a

Voellinger and Freeman 1980, 1982

Voellinger, Freeman, Hale, and Voellinger 1980

No Date

Baskin 1976b

Raab 1982

Richner and Bagot 1978

SURVEYS (urban)

Brown, Widmer, Govaars, and Rubenstein 1985

Fox, A. 1979c

Fox, A. and Ivey 1979

Haske11 and McIntosh 1984

Katz, P. 1978

Moore 1984a, 1984c

TOWNS AND COMMUNITIES

Aurora

McGuff and Roberson 1974

Bear Grass

Voellinger, Brandimarte, and Voellinger 1983

Buffalo

Richner and Lee 1977 
TOWNS AND COMMUNITIES (continued)

Burnam's Settlement

Keller and Campbe11 1984

Clarksville

Briggs 1971

Dimmit's Point Landing

Fritz 1975

Dreyer

Fox, D., Mallouf, O'Malley, and Sorrow 1974

Harmony Hill

Clark and Ivey 1974

Harris Chape1

Glander and Victor 1984

Indianola

Briggs 1971

Fritz 1975

Leaday

Freeman and Freeman 1981

Nuecestown

Hall, Grombacher, and Dibble 1974

Oseola

Bond, Glander, and Brandimarte 1984

Pilares

Johnson 1977

Quintana

Fox, A., Ivey, and Markey 1981 
TOWNS AND GOMMUNITIES (continued)

Roma

O'Malley, Bobbitt, and Scurlock 1976

Ruidosa

Johnson 1977

Rutledge

Mercado-Allinger and Ragsdale 1984

San Felipe de Austin

Briggs 1971

Sugar Hill

Glander and Brandimarte 1983

Glander and Victor 1984

Texana

Crosby 1977

Jackson 1977

Mallouf, Fox, and Briggs 1973

Towash

Stephenson 1947, 1970

Troy

Richner and Lee 1977

Vado de Piedras

Johnson 1977

Velasco

Briggs 1971

Fox, A., Ivey, and Markey 1981

Washington-on-the-Brazos

Davis and Corbin 1967

Texas Parks and Wildlife Department 1977c 
TOWNS AND COMMUNITIES (continued)

Miscellaneous

Dibble and Freeman 1979

Fox, D., Whitsett, and Jurgens 1981

Guderjan 1981

Jackson, M. 1977

Kelly 1979

Lorrain, D. and Jackson 1970

Lynn n.d.

Middleton 1982

Moore 1978

Parsons, Corbin, and Tunnell 1965

Richner and Bagot 1978

Richner and Lee 1976

Roberson 1972

Skinner 1982

TRADING POSTS

Eighteenth Century

Fulien 1978

Miroir, Harris, Blaine, and McVay 1973

Wede1 1978

Nineteenth Century

Ing and Kegley 1971

McGuff and Roberson 1974

TRANSPORTATION SITES AND FEATURES (see also Shipwrecks)

Landings

Hall, Grombacher, and Dibble 1974

Moore 1978

Richner and Bagot 1978

Lock and Dam Systems

Richner and Bagot 1978

Rail Stops (nineteenth century)

Mercado-A1linger and Ragsdale 1984 


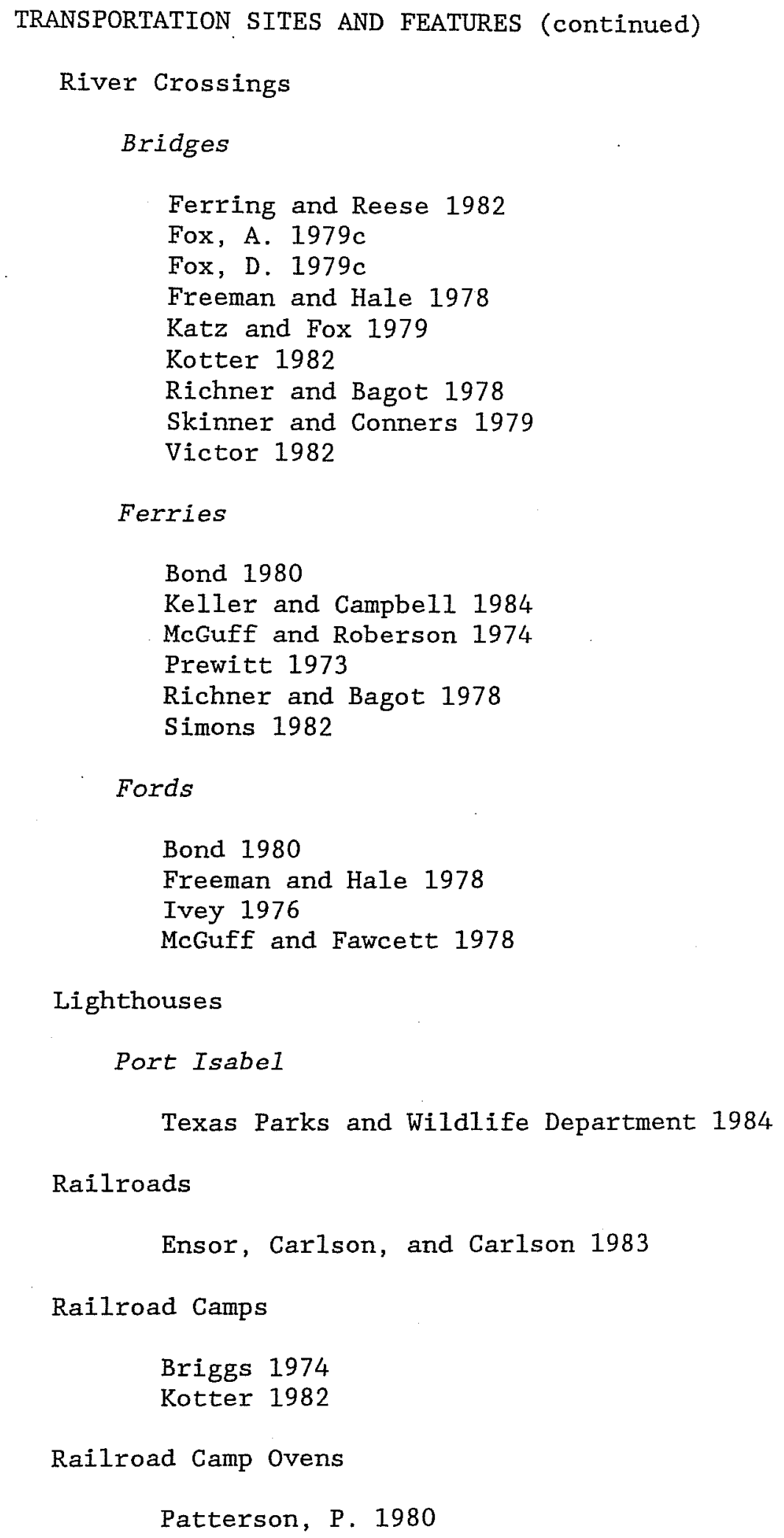


TRANSPORTATION SITES AND FEATURES (continued)

Roads and Trails

Dibble and Freeman 1979

Freeman and Hale 1978

Hall, Grombacher, and Dibble 1974

McGuff and Roberson 1974

Prewitt and Grombacher 1974

Richner and Bagot 1978

Voellinger 1980

Stagecoach Stops (see also Inns/Stagecoach Stops)

Day, Day, and Prewitt 1981

Freeman and Hale 1978

Tramways

Glander and Brandimarte 1983

Glander and Victor 1984

TRASH DUMPS AND SCATTERS

Bandy 1981

Bond, Glander, and Brandimarte 1984

Carlson, Assad, Roemer, and Carlson 1983

Carter, S. 1973

Glark 1984

Cliff, Carter, and Verrett 1974

Coffman and Freeman 1985

Coleman, Carlson, and Carlson 1984

Comstock, Grombacher, and Dibble 1973

Day, Day, and Prewitt 1981

Everett 1981

Fields, Freeman, and Kotter 1983

Fox, D. 1980b

Fox, D., Mallouf, O'Malley, and Sorrow 1974

Freeman 1978

Freeman and Freeman 1981

Glander and Brandimarte 1983

Glander and Victor 1984

Guffee 1980

Hall, Black, and Graves 1982

Keller and Campbell 1984

Kotter 1981a, 1981b

Lynn, Fox, and O'Malley 1977

McGuff 1978

McGuff and Fawcett 1978

Mallouf 1975

Mallouf, Fox, and Briggs 1973

Mercado-Allinger 1983

Mercado-A1linger, Prewitt, and Ragsdale 1984 
TRASH DUMPS AND SCATTERS (continued)

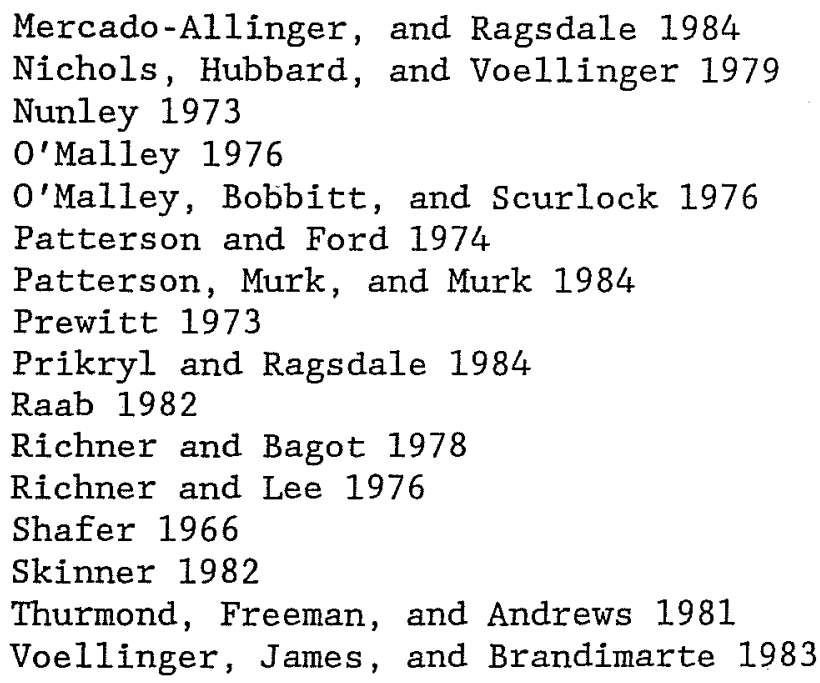

WATER SOURCES AND CONTROL STRUCTURES

Acequias

Alamo Madre

Fox, A. 1979 c, 1985

Katz and Fox 1979

Schuetz $1970 \mathrm{~b}$

Alazan

Assad 1978

Fox, A. 1978

San Pedro

Assad 1978

Fox, A. 1978

Frkuska 1981

Valdez and Eaton 1979

Upper Labor

Fox, A. 1979c

Katz, S. and Fox 1979

Cisterns

Boice 1980

Bond, Glander, and Brandimarte 1984

Brown, Widmer, Govaars, and Rubenstein 1985

Carlson 1984

Fox, D., Mallouf, O'Malley, and Sorrow 1974 
WATER SOURCES AND CONTROL STRUCTURES (continued)

\section{Cisterns (continued)}

Fox, D., Whitsett, and Jurgens 1981

Freeman 1978

Freeman and Freeman 1981

Mercado-Allinger and Ragsdale 1984

Nichols, Hubbard, and Voellinger 1979

Prewitt 1984

Prikryl and Ragsdale 1984

Texas Archeological Survey - Research Staff 1974

Voellinger and Freeman 1982

Voellinger, James, and Brandimarte 1983

Dams

Fox, A. $1979 c$

Howard and Freeman 1984

Irrigation Structures

Johnson 1977

Lock and Dam Systems

Richner and Bagot 1978

Pumping Plants

Kelly, T. 1979

Springs

Freeman and Hale 1978

Johns on 1977

Spring Houses

Coleman, Carlson, and Carlson 1984

Mercado-Allinger and Ragsdale 1984

Waterworks Buildings and Canals

Katz and Fox 1979

Waterworks Canals and Pumphouses

Fox, A. 1979c 
WATER SOURCES AND CONTROL STRUCTURES (continued)

We1ls

Brown, Widmer, Govaars, and Rubenstein 1985

Fox, D., Mallouf, O'Malley, and Sorrow 1974

Freeman 1978

Freeman and Freeman 1981

Glander and Victor 1984

Nichols, Hubbard, and Voellinger 1979

Prikryl and Ragsdale 1984

Stickney and Stickney 1975

Voellinger and Freeman 1980

Voellinger, Freeman, Hale, and Voellinger 1980

Voellinger, James, and Brandimarte 1983

Windmills

Voellinger, James, and Brandimarte 1983 
COUNTY

\section{ANDERSON}

Moore 1978

Richner and Bagot 1978

Richner and Lee 1976, 1977

ARANSAS

Briggs 1971

McClenny, Voellinger, and Ing 1978

Texas Parks and Wildlife Department 1978

AUSTIN

Briggs 1971

Lorrain, D. 1971

Pevey and Van Cleve 1981

\section{BANDERA}

Hester 1975

\section{BASTROP}

Greer, G. 1983

Kelly and Roemer 1981

Skelton and Freeman 1980

Taylor 1986

Taylor, Fox, and Cox 1986

$B E E$

Briggs 1971

Campbel1 and Campbel1 1981

BELL

Carlson 1984

BEXAR

Assad 1978

Campbell and Campbe11 1985

Clark 1974a, 1974b, 1976, 1978, 1980a, 1984

Clark and Prewitt 1979

Cook 1980

Eaton 1980, 1981

Fawcett and McGuff 1969

Fox, A. 1977, 1978, 1979a, 1979c, 1981, 1983, 1985, n.d.a, n.d.b

Fox, A., Bass, and Hester 1976 
BEXAR (continued)

Fox, A. and Highley 1985

Fox, D. 1970, 1979b, 1980b

Fox, D., Scurlock, and Clark 1977

Fox, D., Valdez, and Bobbitt 1978

Frkuska 1981

Gerstle, Kelly, and Assad 1978

Greer, J. 1967

Hall, Grombacher, and Dibble 1974

Harris, I. 1967

Henderson and Clark 1984

Hester 1975, 1977

Hudson, Lynn, and Scurlock 1974

Humphreys 1971

Ivey 1978a, 1978b, 1979, n.d.

Jones, C. 1983

Katz, P. 1977, 1978

Katz and Fox 1979

Leutenegger 1977

Mitche11 1974, 1980

Olsen and Tunnel1 1975

Roberson and Medlin 1976

Schuetz 1966, 1968, 1969a, 1969b, 1970a, 1970b, 1973, 1974, 1980a, 1980b, 1983

Scurlock 1976

Scurlock, Benavides, Isham, and Clark 1976

Scurlock and Fox 1977

Scurlock and Hudson 1973

Scurlock and Powers 1975

Smith H. 1980, 1981

Sorrow 1972

Texas Parks and Wildlife Department $1977 \mathrm{~b}$

Tunnell 1966

Valdez and Eaton 1979

BLANCO

Carter, S. 1973

BOSQUE

Stephenson 1947,1970

BOWIE

Harris R. K. and Harris 1967, 1978, 1980

Miroir, Harris, Blaine, and McVay 1973

Wede1 1978

Woodal1 1967 


\section{BRAZORIA}

Briggs 1971

Crouch 1982

Fox, Ivey, and Markey 1981

Hal1, Grombacher, and Dibble 1974

Hole 1974

Ippolito and Baxter 1976

Lynn n.d.

McGuff and Cox 1973

Pollan 1984

Roemer, Carlson, and Assad 1983

Texas Archeological Survey - Research Staff 1974

Texas Parks and Wildlife Department 1983c

BRAZOS

Carlson 1983

Kotter 1982

Sorrow and Cox 1973

BREWSTER

Guffee 1976a

Hester and Eaton 1982

Kelley 1952, 1953

Morrow 1975

Newcomb and Kirkland 1967

Smith, V. 1942, 1946

Tunnel1 1981

BRISCOE

Malone 1970

Willey, Harrison, and Hughes 1978

BROOKS

Hester 1979

CALDWELL

Hester 1975

CALHOUN

Arnold 1982

Briggs 1971

Comstock, Grombacher, and Dibble 1973

Fritz 1975

Hall, Grombacher, and Dibble 1974 
CALHOUN (continued)

Hester 1975

Scurlock and Schroeder 1971

\section{CAMERON}

Arnold 1976, 1977

Arnold and Clausen 1975

Arnold and Weddle 1979

Baxter and Killen 1976

Boggs n.d.

Bond 1979

Briggs 1971

Hall and Grombacher 1974

Hays and Herrin 1970

Heck 1978

Hester 1978

Hester and Eaton 1982

Nichols $1981 \mathrm{~b}$

Shafer 1974

Texas Parks and Wildlife Department 1984

Tunne11 and Jensen 1971

\section{CASS}

Dickinson 1941

Harris, R. K., Harris, and Miroir 1980

\section{CHAMBERS}

Briggs 1971

Fox, A., Day, and Highley 1980

Fullen 1978

Gilmore 1974a

Middleton 1982

Moore 1978

Richner and Bagot 1978

Shafer 1966

Tunnell and Ambler 1967

\section{CHEROKEE}

Jensen 1968

CLAY

Harris, I. M. 1966

Ozee 1955 
COLEMAN

Freeman and Freeman 1981

Nichols 1981a

COLLIN

Moore 1978

Richner and Bagot 1978

\section{COLORADO}

Dibble and Freeman 1979

Ha11, Grombacher, and Dibble 1974

Keller and Campbe11 1984

COMAL

Hester 1975

CONCHO

Freeman and Freeman 1981

Newcomb and Kirkland 1967

Nichols 1981a

Smith, V. 1942, 1946

\section{CROCKETT}

Black 1974

Clark 1972

Hays and Jelks 1966

Hester 1968

Texas Parks and Wildlife Department 1976a

Walters and Rogers 1975

\section{CROSBY}

Parker 1979, 1983

Parsons 1967

\section{DALILAS}

Ferring 1983

Ferring and Reese 1982

Harris, R. K. 1951

Moore 1978 
DALLAS (continued)

Richner and Bagot 1978

Skinner and Conners 1979

DAWSON

Bennett 1968

Hart 1972

DENTON

Greer, G. 1983

Harris, R. K. 1940

Moore 1978

Nunley 1973

Richner and Bagot 1978

Skinner 1982

DEWITT

Fox, D., Mallouf, O'Malley, and Sorrow 1974

Hall, Grombacher, and Dibble 1974

Hester 1975

DICKENS

Parsons 1967

DIMMIT

Fox, A. and Cox 1983

Hester 1970,1984

Mitchell 1974

DUVAL

Prewitt and Nance 1980

EDWARDS

Marmaduke and Whitsett $1975 \mathrm{c}$

EL PASO

Black, Burnett, and Ing 1978

Krone 1978

Morrow 1978

Newcomb and Kirkland 1967

Smith, V. 1946

Texas Parks and Wildlife Department 1977c

Thompson 1980 
ELLIS

Ferring 1983

Ferring and Reese 1982

Moore 1978

Richner and Bagot 1978

Skinner and Conners 1979

FANNIN

Harris, R. K. 1953b

Lynn 1978

Moore 1978

Richner and Bagot 1978

\section{FAYETTE}

Carter and Ragsdale 1976

Dibble and Freeman 1979

Jackson and Skelton 1975

Keller and Campbel1 1984

Pevey and Van Cleve 1981

Texas Parks and Wildlife Department 1980

FISHER

Ray and Jelks 1964

FLOYD

Doran and Malina 1974

Guffee 1976b

Harris, R. K. and Harris $1975 \mathrm{~b}$

Parker 1982

Word and Fox 1975

FORT BEND

Hudgins 1984a

McGuff and Cox 1973

FREESTONE

Jackson 1982

Moore 1978

Pliska, Nightengale, and Jackson 1980

Raab 1982

Richner and Bagot 1978

Richner and Lee 1976, 1977

Voellinger, Brandimarte, and Voellinger 1983

Voellinger and Freeman 1980, 1982

Voellinger, Freeman, Hale, and Voellinger 1980 
FRIO

Mitche11 1974

\section{GALVESTON}

Anderson 1980, 1981, 1983

Campbell 1956

Fields and Jackson 1984

Kindal1 1984

McGuff and Cox 1973

McGuff and Ford 1974

Mercado-Allinger, Fields, Gilmore, and Reese 1984

Moore $1984 \mathrm{c}$

Moore and Anderson 1984

Wetzel 1980a, 1980b

Widmer and Sullivan 1984

GARZA

Riggs 1965

\section{GILLESPIE}

Brooks and Baskin 1976

Gilmore 1973a

Greer, J. 1979

Ing 1970

Johnson, M. 1979

Kotter and Nance 1980

McReynolds, R. L. 1982

Tunnell and Jensen 1969

\section{GOLIAD}

\section{Briggs 1971}

Gilmore 1974b, $1974 \mathrm{c}$

Harris, R. K. and Harris 1974a, 1974b, 1975a

Hester 1975, 1977

Mounger 1959

Reed 1938

\section{GONZALES}

Fox, D., Mallouf, O'Malley, and Sorrow 1974

Hall, Grombacher, and Dibble 1974

Hester 1975

Kotter 1981a 


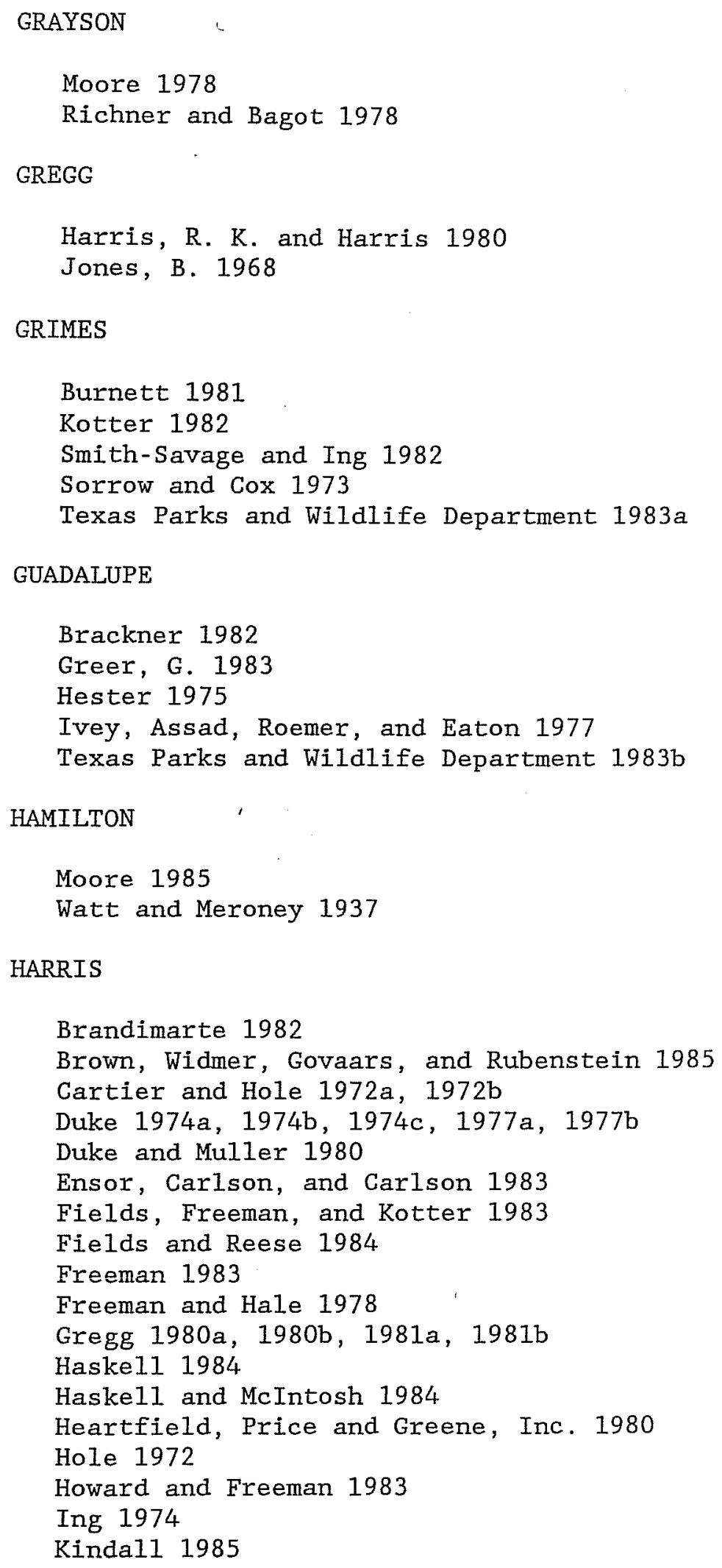


HARRIS (continued)

McGuff and Cox 1973

McIntosh 1982

McIntosh and Moore 1983

Mercado-Allinger, Fields, Gilmore, and Reese 1984

Moore 1984a, 1984b

Patterson, Murk, and Murk 1984

Voellinger 1982a, 1982b

Whitsett n.d.

HARRISON

Freeman 1978

Garrison 1983

Greer, G. 1983

Harris, R. K. and Harris 1980

Jones, B. 1968

Luke 1978

Nichols, Hubbard, and Voellinger 1979

Voellinger 1980

Weir 1973

HAYS

Hester 1975

Roberson 1972

\section{HENDERSON}

Guderjan 1981

Moore 1978

Richner and Bagot 1978

Richner and Lee 1976, 1977

\section{HIDALGO}

Day, Day, and Prewitt 1981

Hester 1979

Hester and Eaton 1982

HILL

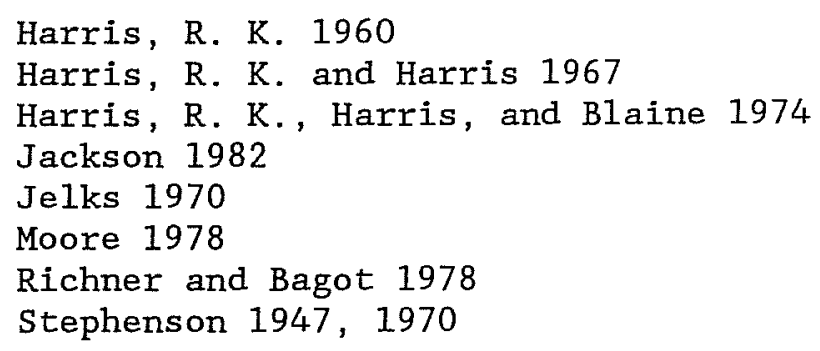


HILI (continued)

Watt 1937

Watt and Meroney 1937

HOCKLEY

Boyd 1982

HOOD

Moore 1978

Richner and Bagot 1978

HOUSTON

Moore 1978

Richner and Bagot 1978

Texas Parks and Wildlife Department 1974b

HUDSPETH

Johnson, C. 1977

Smith, V. 1946

Tunne11 1981

HUTCHINSON

Bousman 1974

JACK

Dickson 1976

Ippolito 1977

Lorrain, D. 1972, 1973

Roberson and Ing 1974

Texas Parks and Wildlife Department 1975c

Westbury 1976, 1977

JACKSON

Crosby 1977

Fawcett 1980, 1983

Freeman 1980

Fritz 1975

Greer, G. 1983

Hall, Grombacher, and Dibble 1974

Jackson, M. 1977

McGuff 1978

McGuff and Fawcett 1978

Mallouf, Fox, and Briggs 1973 
JASPER

Few 1982

JEFF DAVIS

Johnson, C. 1977

Marmaduke and Whitsett 1975a

Smith, V. 1942, 1946

JEFFERSON

Holtzapple and Roberson 1976

McGuff and Roberson 1974

Prewitt 1973

JIM HOGG

Kotter 1981b

JIM WELLS

Hester 1979

JOHNSON

Moore 1978

Richner and Bagot 1978

KARNES

Hester 1975

Kotter and Guy 1980

KAUFMAN

Moore 1978

Richner and Bagot 1978

KENDALL

Hester 1975

\section{KENEDY}

Arnold 1976, 1977

Arnold and Clausen 1975

Arnold and Weddle 1979

Hays and Herrin 1970

Scurlock, Lynn, and Ray 1974 
KENT

Thurmond, Freeman, and Andrews 1981

KERR

Hester 1975

KING

Thurmond, Freeman, and Andrews 1981

KINNEY

Hester and Eaton 1982

KLEBERG

Hays and Herrin 1970

Hester 1979

Scurlock, Lynn, and Ray 1974

KNOX

Redder 1972

\section{LAMAR}

Bastian 1967

Black 1981

Davison and Harris 1974

Harris, R. K. 1946, 1953b

Harris, R. K. and Harris 1967, 1980

Harris, R. K., Harris, Blaine, and Blaine 1965

Harris, R. K. and Shiner 1973

Texas Parks and Wildlife Department 1976c

Woodal1 1967

LAMB

Guffee 1980

\section{LAVACA}

Kotter 1981a

Pevey and Van Cleve 1981

LEE

Kelly and Roemer 1981

Taylor 1986 
LEON

Fields 1984

Kotter 1982

Moore 1978

Richner and Bagot 1978

Voellinger, Brandimarte, and Voellinger 1983

Voellinger and Freeman 1980

Voellinger, Freeman, Hale, and Voellinger 1980

\section{LIBERTY}

Arnold 1974

Chaffin-Lohse 1978

Fox, A., Day, and Highley 1980

Fullen 1978

Moore 1978

Moore and Heartfield 1982

Prewitt 1973

Richner and Bagot 1978

LIMESTONE

Davison and Harris 1974

Harris, R. K. and Harris 1967, 1969a, 1969b, 1969c, 1969d Moore 1978

Prewitt and Grombacher 1974

Richner and Bagot 1978

Voellinger, Brandimarte, and Voellinger 1983

Voellinger and Freeman 1980, 1982

Voellinger, Freeman, Hale, and Voellinger 1980

LIVE OAK

Bandy 1981

Briggs 1971

Brown, Potter, Hall, and Black 1982

Campbe11 and Campbell 1981

Everett 1981

Fox, A. 1984, 1986

Fox, D. 1982

Fox, D. and Lynn 1976

Hall, Black, and Graves 1982

Lynn, Fox, and O'Malley 1977

Mallouf 1975

LLANO

Greer, J. 1979 


\section{LUBBOCK}

Johnson, E., Holliday, Kaczor, and Stuckenrath 1977

Newcomb 1955

MCLENNAN

Bell, Jelks, and Newcomb 1967

Fox, D. 1979c

Harris, I. 1967

Harris, R. K. and Harris 1967

Perino 1968

Redder 1967

Story 1985

\section{MCMULLEN}

Bandy 1981

Briggs 1971

Campbel1 and Campbel1 1981

Everett 1981

Fox, A. 1984, 1986

Fox, D. and Lynn 1976

Hall, Black, and Graves 1982

Lynn, Fox, and O'Malley 1977

\section{MADISON}

Ivey 1976

Kotter 1982

Moore 1978

Richner and Bagot 1978

Sorrow and Cox 1973

\section{MASON}

Parsons 1972

\section{MATAGORDA}

Arnold 1982

Dibble and Freeman 1979

Dibble and Jackson 1980

Fritz 1975

Ha11 and Ford 1974

Hal1, Grombacher, and Dibble 1974

\section{MAVERICK}

Hester and Eaton 1982 
MEDINA

Hester 1975

Texas Parks and Wildlife Department 1976b

MENARD

Black and Ing 1980

Carter, E. 1974

Gilmore 1967

Green 1969

Ivey 1981

Texas Parks and Wildlife Department 1975a, 1975b, 1977a, 1982

\section{MIDLAND}

Shawn 1975

Stickney and Stickney 1975

MILAM

Betancourt and Lynn 1977

Carlson, Assad, Roemer, and Carlson 1983

Gilmore 1969, 1982

Hester 1977

MONTAGUE

Bastian 1967

Bell, Jelks, and Newcomb 1967

Blaine 1967

Davison and Harris 1974

Harris, R. K. and Harris 1961, 1967

Perino 1968

Steen 1953

Witte 1938

Wooda11 1967

MONTGOMERY

Greer, G. 1983

Malone, Greer, and Simons 1979

Voellinger 1982a

MOORE

Bousman 1974 


\section{NACOGDOCHES}

Corbin and Kisling 1983

Harris, R, K. and Harris 1967

Phillips 1982

Prewitt, Clark, and Dibble 1972

Story 1982

NAVARRO

Jurney 1986

Moore 1978

Raab 1982

Richner and Bagot 1978

Richner and Lee 1976, 1977

NUECES

Briggs 1971

Hall, Grombacher, and Dibble 1974

Hester 1979

Ing 1976

Patterson and Ford 1974

Raun 1964

OLDHAM

Marmaduke and Whitsett $1975 d$

ORANGE

McGuff and Roberson 1974

PALO PINTO

Bond 1980

Harris, R. K. and Harris 1967

Jackson, M. 1975

\section{PANOLA}

Clark and Ivey 1974

Glander and Brandimarte 1983

Glander and Victor 1984

Harris, R. K. and Harris 1980

\section{PARKER}

Moore 1978

Richner and Bagot 1978 
PECOS

Eagleton 1955

Walters and Rogers 1975

POLK

Denton 1983

Moore 1978

Richner and Bagot 1978

POTTER

Bousman 1974

\section{PRESIDIO}

Baskin 1976a, 1976b

Hester and Eaton 1982

Holliday and Ivey 1974

Ing and Kegley 1971

Ing and Roberson 1974

Jelks 1969

Johnson, C. 1977

Lowery 1969

Newcomb and Kirkland 1967

Pope and Richey 1966

Smith, V. 1946

Texas Parks and Wildlife Department 1974a

Tunne11 1981

\section{RAINS}

Blaine and Harris 1966

Davis, Gilmore, Harper, Harris, Jelks, and Yancy 1966

Davison and Harris 1974

Duffield and Jelks 1961

Harper, Harper, Harris, Harris, Jelks, and Woodall 1966

Harris, R. K. 1962

Harris, R. K. and Blaine 1966

Harris, R. K. and Harris 1962, 1967, 1980

Harris, R. K., Harris, and Woodall 1966

Harris, R. K. and Shiner 1973

Harris, R. K. and Tunnell 1966

Jelks 1967

Johnson, L. and Jelks 1968

Perino 1968

Woodal1 1967 
REAL

Cook 1981

Hester 1977

Marmaduke and Whitsett $1975 \mathrm{c}$

Tunnell and Newcomb 1969

RED RIVER

Harris, R. K. 1953a

Harris, R. K. and Harris 1980

Skinner, Harris, and Anderson 1969

REEVES

Smith, V. 1946

REFUGIO

Comstock, Grombacher, and Dibble 1973

Hal1, Grombacher, and Dibble 1974

Hester 1979

ROBERTSON

Kotter 1982

Prewitt and Grombacher 1974

RUNNELS

Freeman and Freeman 1981

Nichols 1981a

RUSK

Clark and Ivey 1974

Greer, G. 1983

Harris, R. K. and Harris 1980

Jackson 1982

Jones, B. 1968

Moncure 1984

Moncure and Jackson 1982

SABINE

Simons 1982

Skinner 1979

SAN AUGUSTINE

Corbin, Kalina, and Alex 1980 
SAN JACINTO

Hsu 1969

Moore 1978

Richner and Bagot 1978

SAN PATRICIO

Hal1, Grombacher, and Dibble 1974

Hester 1979

Prewitt 1984

SAN SABA

Newcomb and Kirkland 1967

SCURRY

Riggs 1982

SHACKELFORD

Fox, A. 1973, 1976

Olds 1969

Yates 1973, 1975

SHELBY

Coleman, Carlson, and Carlson 1984

SMITH

Skinner 1971

STARR

Hester and Eaton 1982

o'Malley 1976

O'Malley, Bobbitt, and Scurlock 1976

STEPHENS

Conger 1953

Smith, V. 1946

STONEWALL

Thurmond, Freeman, and Andrews 1981 


\section{TARRANT}

Ferring 1983

Ferring and Reese 1982

Granberry 1977

Lorrain, P. 1979

Moore 1978

Richner and Bagot 1978

Skinner and Conners 1979

TERRELL

Collett 1984

Newcomb and Kirkland 1967

Smith, V. 1946

Walters and Rogers 1975

TITUS

Gliff, Carter, and Verrett 1974

TOM GREEN

Bell, Klein, and Hoffman 1980

Coffman and Ground 1970

Mobley 1976

Pettengill 1977

TRAVIS

Black 1980

Boice 1980

Briggs 1981

Brown 1977

Durrenberger 1965

Hoffrichter 1981

Howard and Freeman 1984

McEachern and Ralph 1980a, 1980b

Moore, Weir, Keller, Jarvis, Yates, Jelks, and Bandy 1972

Olds 1967

Prikryl and Ragsdale 1984

Roberson 1974

Voellinger, James, and Brandimarte 1983

\section{TRINITY}

Moore 1978

Richner and Bagot 1978 
UVALDE

Hester 1975

Nelson 1981

Smith, R. 1984

VAL VERDE

Briggs 1974

Hester and Eaton 1982

Kirkland 1942

Marmaduke and Whitsett 1975b

Patterson 1980

Smith, V. 1946

Turpin 1982

\section{VAN ZANDT}

Guderjan 1981

Moore 1978

Richner and Bagot 1978

VICTORIA

Briggs 1971

Fox, A. 1979b

Fox, A. and Livingston 1979

Gilmore 1973b

Harris, R. K. and Harris 1973

Hester 1975, 1979

Mitchell and Highley 1982

\section{WALKER}

Bond, Glander, and Brandimarte 1984

Clark 1980b

Moore 1978

Pevey 1981

Richner and Bagot 1978

WALLER

Freeman and Hale 1978

\section{WASHINGTON}

Davis, E. and Corbin 1967

Haaskar1 1957

Lorrain, D. and Jackson 1970

Parsons, Corbin, and Tunnell 1965

Texas Parks and Wildlife Department 1977d 
WEBB

Fox, D. 1979a

Heck 1978

Hester 1978

Hester and Eaton 1982

Ivey and Medlin 1977

Ivey, Medlin, and Eaton 1977

Kelly 1979

McReynolds, M. 1981

WHARTON

Briggs 1971,1983

Hal1, Grombacher, and Dibble 1974

Hudgins 1982, 1984a, 1984b, 1985a, 1985b

WILLACY

Arnold 1976, 1977

Arnold and Clausen 1975

Arnold and Weddle 1979

Day, Day, and Prewitt 1981

Hays and Herrin 1970

Mercado-Allinger 1983

Olds 1976

WILLIAMSON

Coffman and Freeman 1985

Fox, D., Whitsett, and Jurgens 1981

Freeman 1976

Mercado-Allinger, Prewitt, and Ragsdale 1984

Mercado-Allinger and Ragsdale 1984

Ralph 1982

Victor 1982

WILSON

Hester 1975

Ivey 1983

Ivey and Fox 1981

Jones, C. and Fox 1983

Taylor and Fox 1985

WISE

Moore 1978

Richner and Bagot 1978 


\section{YOAKUM}

Suhm 1962

\section{ZAPATA}

Hester and Eaton 1982

\section{ZAVALA}

Hester 1970

Mitchel1 1974

NO COUNTIES MENTIONED

Lorrain 1968, 1970

Taylor 1960

STATEWIDE/REGIONAL SYNTHESES

Aten 1983

Campbe11 and Campbel1 1981

Davis, E. M. 1970

Fox, D. 1980a, 1983

Gilmore 1978

Hester 1980

Humphreys and Singleton 1978

Jackson, A. T. 1938, 1971

Scurlock and Powers 1973

Skeels 1972

Williams 1961 